
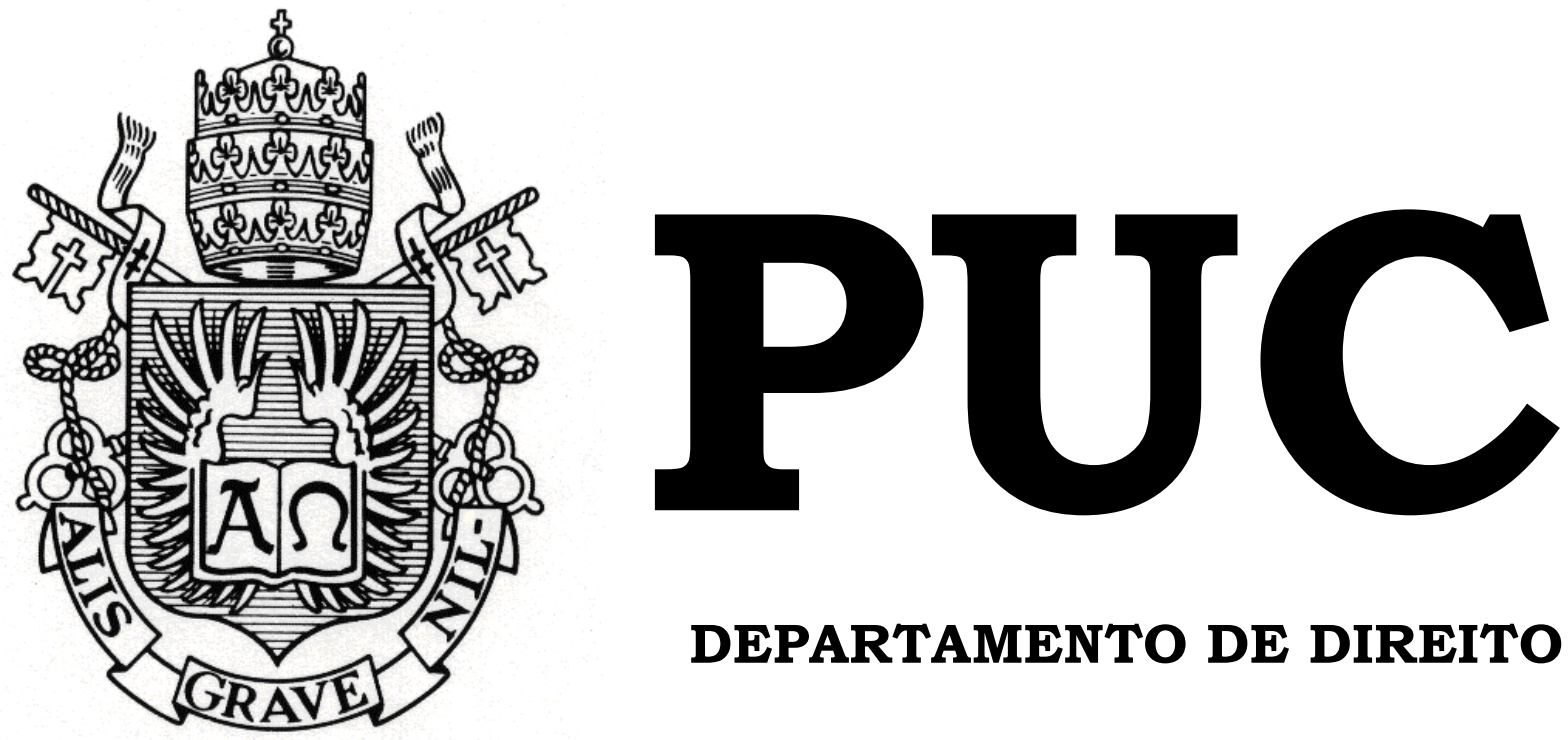

DEPARTAMENTO DE DIREITO

\title{
MULHERES NO CÁRCERE: A QUESTÃO DE GÊNERO E SEUS RESPECTIVOS REFLEXOS NO SISTEMA PRISIONAL
}

\author{
por \\ JULIANA DE MELLO BONTEMPO \\ ORIENTADORA: AGNES CHRISTIAN CHAVES \\ FARIA
}

2018.1

PONTIFÍCIA UNIVERSIDADE CATÓLICA DO RIO DE JANEIRO RUA MARQUÊS DE SÃO VICENTE, 225 - CEP 22453-900 RIO DE JANEIRO - BRASIL 


\title{
MULHERES NO CÁRCERE: A QUESTÃO DE GÊNERO E SEUS RESPECTIVOS REFLEXOS NO SISTEMA PRISIONAL
}

\author{
por
}

\section{JULIANA DE MELLO BONTEMPO}

Monografia apresentada ao Departamento de Direito da Pontificia Universidade Católica do Rio de Janeiro (PUC-Rio) como requisito parcial para a obtenção do título de Bacharel em Direito.

Orientadora:

Agnes

Christian Chaves Faria 
Dedico este trabalho à todas as mulheres que lutaram, lutam e ainda lutarão bravamente contra as opressões patriarcais do sistema. Dedico-o, em especial, àquelas encarceradas, invisíveis, necessitadas de voz. 


\section{Agradecimentos}

Aos meus pais, por investirem em todos os meus sonhos, por nunca deixarem de acreditar em mim e, enfim, tornarem tudo isso possível. A vocês, esta vitória é dedicada.

Em especial, à minha querida avó, fonte de inspiração e força. Obrigada por afirmar imenso orgulho de mim e ser a maior fã desde que me entendo por gente.

À minha cachorrinha, fiel escudeira nestes quatorze anos de companheirismo impecável.

À minha namorada, que sempre me apoia incondicionalmente e esteve ao meu lado em todos os momentos nesta época árdua que é o final da graduação. Obrigada pelo carinho, amor e paciência a mim dedicados.

Aos amigos da Pontifícia, por terem dividido esta jornada insana de seis anos comigo. Agradeço imensamente por todas as boas memórias.

Ao amigo Marcos, grande parceiro de intercâmbio, por compartir de seus conhecimentos e me acudir todas as vezes que necessitei de ajuda nos estudos.

À minha orientadora, que depositou confiança ao meu tema do primeiro ao último dia, me forneceu todo o suporte para a construção deste trabalho e conseguiu lidar com todas as minhas ansiedades e angústias diárias.

Aos meus professores da graduação, que não só foram responsáveis por minha formação acadêmica e profissional, como também pela construção de muitas de minhas convicções pessoais.

À universidade, por me proporcionar a criação de laços com pessoas incríveis, ambiente criativo à aprendizagem, autoconhecimento e, principalmente, cerveja às quintas-feiras na vila dos diretórios. 
Ao ilustre Ludwig Van Beethoven, pela composição da Sonata $n^{\circ}$ 14, Op. $27, \mathrm{n}^{\mathrm{o}} 2$, trilha sonora oficial de minha vida acadêmica. Sem ela, nenhuma concentração teria sido possível.

Por fim, ao universo, agradeço pela oportunidade e as boas vibrações incessantes. 


\section{Resumo}

O presente trabalho dedica-se a compreender a questão de gênero como fator de desigualdade e seus respectivos reflexos no sistema prisional. Para isso, trata-se da representação feminina perante à sociedade e como isso se reproduz na realidade criminal. Para o entendimento acerca do fenômeno do encarceramento em massa feminino, a análise perpassa pela situação social da mulher brasileira antes de cometer o delito e os motivos que a fizeram participar de atividades ilícitas. Inclusive, o tráfico de entorpecentes, crime que mais encarcera mulheres no país, é utilizado como base argumentativa da seletividade penal e vulnerabilidade de gênero. Por fim, demonstra-se como, mesmo depois de presa, o estigma vigente sob aspectos do patriarcado e violência contra a mulher imperam nas instituições prisionais em muitos aspectos. A mulher é completamente esquecida e invisibilizada dentro de um sistema criado, desenvolvido e voltado para homens. Por isso, diante de suas necessidades específicas não atendidas, vale-se da denúncia perante a violação de seus direitos, sobretudo no que tange à prisão domiciliar, tema este em voga na atual conjuntura e presente nas recentes discussões do país.

\section{Palavras-chave}

Brasil; Mulheres Encarceradas; Questão de Gênero; Desigualdade; Tráfico de Drogas; Sistema Prisional; Perspectiva Feminista; Violações de Direitos. 


\section{Sumário}

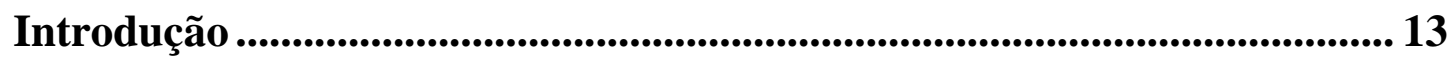

Capítulo I - A Desigualdade de Gênero no Contexto Jurídico-Criminal ...15 1.1. Formação brasileira e questão social: a lógica neoliberal entre capital e

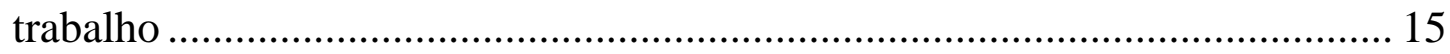

1.2. A questão social sob a perspectiva de gênero ............................................ 19

1.2.1. A divisão sexual do trabalho e feminização da pobreza ......................... 19

1.3. A lógica punitiva da política de drogas e o encarceramento feminino em

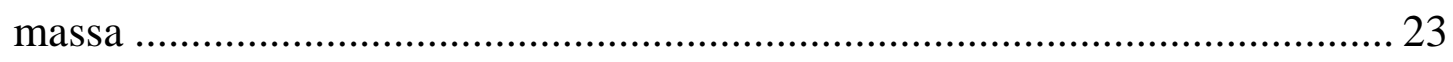

1.4. A solução ao problema do superencarceramento feminino.........................26

Capítulo II - O Perfil da População Prisional Feminina Brasileira e o Fenômeno do Superencarceramento ........................................................................ 28

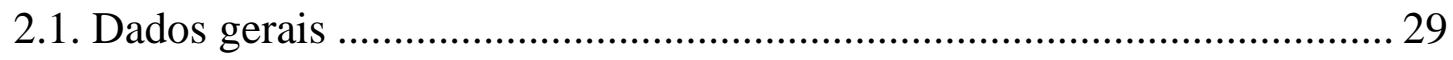

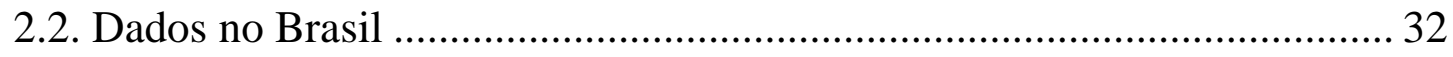

2.3. Perfil das mulheres encarceradas no Brasil ................................................ 34

Capítulo III - Os Direitos das Mulheres Encarceradas e suas Respectivas Violações ......................................................................................................................... 40

3.1. A perpetuação do estigma da mulher dentro do cárcere ............................. 43

3.1.1. Da violação aos direitos dos filhos das mulheres encarceradas .............. 44

3.1.2. Da violação ao direito de estabelecimento prisional próprio à mulher .. 47

3.1.3. Da violação ao direito de acompanhamento médico à mulher grávida.. 51

3.1.4. Da violação ao direito de permanência de agentes penitenciários exclusivamente do sexo feminino ...................................................................5 54 
3.1.5. Da violação ao direito à prisão domiciliar das mulheres abarcadas pelas

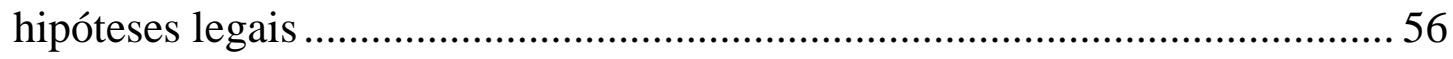

3.1.6. Da violação à vedação que a lei prevê ao uso de algemas em mulheres

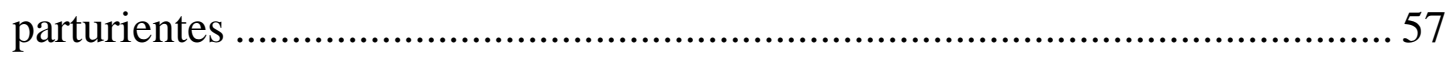

3.1.7. Da violação ao direito ao ensino profissional completo da mulher ....... 60

3.1.8. Das violações gerais a recomendações, tratados ou convenções de âmbito

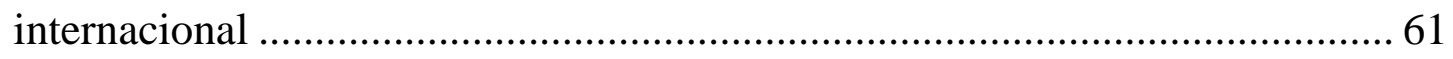

3.2. O desenlace entre efetividade e invisibilidade ........................................... 64

Capítulo IV - O Benefício à Prisão Domiciliar da Mulher perante o Direito do Filho à uma Infância Livre ...................................................................................... 66

4.1. A questão penitenciária sob a ótica feminina ……………….................... 67

4.2. As mulheres encarceradas e o advento da Lei 13.257/2016...................... 69

4.2.1. As modificações produzidas pela Lei 13.257/2016 ao Código de Processo

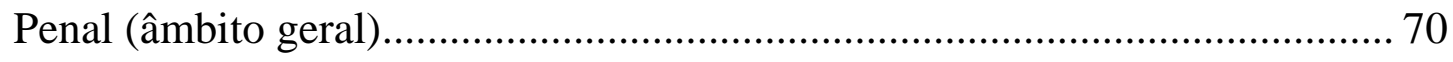

4.3. Conceito de prisão domiciliar.................................................................. 71

4.4. As modificações produzidas pela Lei 13.257/2016 especificamente ao artigo 318 do Código de Processo Penal ...................................................................... 72

4.5. Críticas às novas regras aplicadas à prisão domiciliar ............................... 74

4.5.1. Análise crítica à generalização da benesse prevista em lei ..................... 74

4.5.2. Análise crítica em prol do interesse maior da criança e do incentivo à uma política de desencarceramento....................................................................... 79

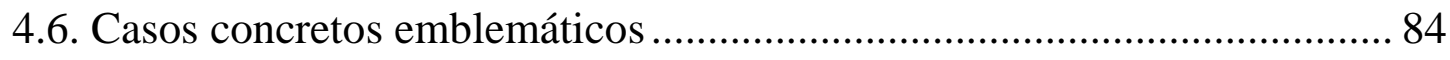

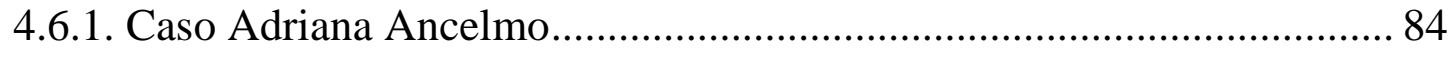

4.6.2. Caso Habeas Corpus $\mathrm{n}^{\mathrm{o}}$ 143.641/SP (HC Coletivo) ............................... 88

4.6.3 Caso Danúbia de Souza Rangel............................................................... 90 


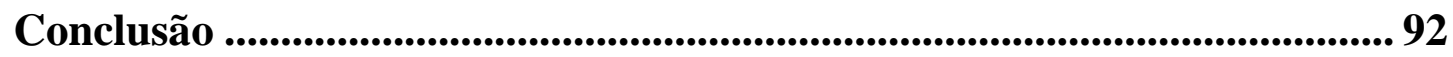

Referências Bibliográficas .....................................................................................95 


\section{Lista de Tabelas}

Tabela 1 - População carcerária feminina (resumo por continente) ................ 29

Tabela 2 - População carcerária feminina (mudanças desde o ano 2000) ....... 30

Tabela 3 - Informações prisionais dos doze países com maior população

prisional feminina do mundo (2017) .............................................................. 31

Tabela 4 - Direitos das mulheres encarceradas e respectivas previsões legais 65

Tabela 5 - Quadro comparativo artigo 318, inciso IV CPP: texto anterior e posterior à alteração advinda da Lei 13.257/2016............................................ 73 


\section{Lista de Gráficos}

Gráfico 1 - Evolução da população de mulheres no sistema penitenciário brasileiro de 2000 a 2014 33

Gráfico 2 - Evolução da população prisional brasileira segundo o gênero de 2000 a 2014

Gráfico 3 - Evolução da taxa de aprisionamento por 100 mil habitantes no Brasil

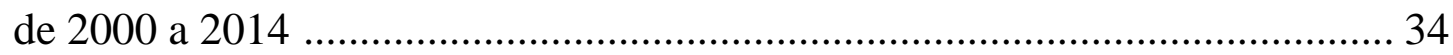

Gráfico 4 - Faixa etária das mulheres privadas de liberdade no Brasil .......... 35

Gráfico 5 - Raça, cor ou etnia das mulheres privadas de liberdade no Brasil 35

Gráfico 6 - Estado civil das mulheres privadas de liberdade no Brasil .......... 36

Gráfico 7 - Escolaridade das mulheres privadas de liberdade no Brasil ........ 36

Gráfico 8 - Continente de proveniência das presas estrangeiras no Brasil ..... 36 Gráfico 9 - Distribuição por gênero dos crimes tentados/consumados entre os registros das pessoas privadas de liberdade no Brasil ..................................... 37

Gráfico 10 - Mulheres privadas de liberdade por natureza da prisão e tipo de

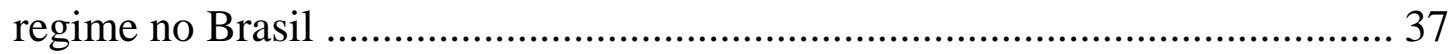

Gráfico 11 - Tempo total de penas da população prisional feminina condenada no Brasil 38 


\section{Lista de Abreviações}

ADPF - Arguição de Descumprimento de Preceito Fundamental

ART. - Artigo

$\mathrm{CADHu}$ - Coletivo de Advogados em Direitos Humanos

CEDES - Centro de Estudos e Debates Estratégicos

CEJIL - Centro pela Justiça e pelo Direito Internacional

CIDH - Comissão Interamericana de Direitos Humanos

CF - Constituição da República Federativa do Brasil de 1988

CNJ - Conselho Nacional de Justiça

$\mathrm{CP}$ - Código Penal

CPP - Código de Processo Penal

DEPEN - Departamento Penitenciário Nacional

DPU - Defensoria Pública da União

ECA - Estatuto da Criança e do Adolescente

FJP - Fundação João Pinheiro

GECAp - Grupo de Estudos Carcerários Aplicados

$\mathrm{HC}$ - Habeas Corpus

IBGE - Instituto Brasileiro de Geografia e Estatística

ICRP - Institute for Criminal Policy Research

INFOPEN - Sistema de Informações Penitenciárias

IPEA - Instituto de Pesquisa Econômica Aplicada

JFRJ - Justiça Federal do Rio de Janeiro

LEP - Lei de Execução Penal

MP - Ministério Público

MPF - Ministério Público Federal

OEA - Organização dos Estados Americanos

OMS - Organização Mundial da Saúde

ONU - Organização das Nações Unidas 
ORG (S). - Organizador (es)

PNAD - Pesquisa Nacional por Amostra de Domicílios

PNUD - Programa das Nações Unidas para o Desenvolvimento

RHC - Recurso em Habeas Corpus

STF - Supremo Tribunal Federal

STJ - Superior Tribunal de Justiça

TJ - Tribunal de Justiça

TJRJ - Tribunal de Justiça do Estado do Rio de Janeiro

TRF - Tribunal Regional Federal

UFRJ - Universidade Federal do Rio de Janeiro 
"Que nada nos defina. Que nada nos sujeite. Que a liberdade seja a nossa própria substância”.

Simone de Beauvoir. 


\section{Introdução}

Historicamente a dominação masculina é instrumentalizada nas relações de poder. Diante do estigma da mulher perante à sociedade e sua vulnerabilidade social, a questão de gênero claramente atua como fator de desigualdade em sua vida, sobretudo quando se trata do sistema de justiça criminal, objeto este do presente trabalho.

O prisma político-econômico do Brasil neoliberal foi o ponto de partida examinado para compreensão da realidade criminal envolvendo mulheres, pois para se discutir sobre gênero, é necessário tratar anteriormente sobre classe e raça. Este preceito inicial é de suma importância no que concerne aos desdobramentos neste trabalho aprofundados. A metodologia utilizada foi a coleta de dados, participação de seminários e pesquisa sobre o tema. A estrutura deste será composta de quatro capítulos no total.

Vale ressaltar que o assunto é abordado sem a pretensão de esgotá-lo, até porque seria inviável em se tratando de tema de tamanha dimensão. O propósito é, na verdade, apontar determinados segmentos escolhidos, buscando seu viés crítico.

No primeiro capítulo será analisado como a questão do gênero permeia a desigualdade em todos os momentos da vida de uma mulher. No caso, o revolvimento histórico contextualizará a situação neoliberal brasileira que contribuiu com a divisão sexual do trabalho e a feminização da pobreza e que a levaram a optar pela inserção na atividade ilícita do tráfico de entorpecentes. Depois, a posição subalterna que esta exerce dentro do próprio comércio de

drogas que a faz estar mais apta a flagrantes e, consequentemente, encarcerada.

No segundo, dados consolidados sobre o desenfreado fenômeno do superencarceramento de mulheres são trazidos à tona em âmbitos nacional e mundial. Ademais, constrói-se o perfil da população prisional feminina 
brasileira, enaltecendo aspectos tais quais: faixa etária; raça, cor ou etnia; estado civil; escolaridade; continente de proveniência; tipos penais enquadrados; natureza da prisão e regime e; tempo total da pena. Conhecer estas mulheres a fundo, nos dão a perspectiva sobre suas realidades.

O terceiro capítulo, por sua vez, tem o objetivo de demonstrar a perpetuação estrutural do estigma feminino dentro das próprias instituições prisionais, nas quais indivíduos do gênero em questão são diariamente invisibilizados. Para isso, será realizado um levante sobre as legislações que possuem recorte de gênero frente às necessidades específicas femininas, mas que simplesmente não são cumpridas ou aplicadas.

Por último, aborda-se tema de suma relevância na atual conjuntura: a prisão domiciliar. Aqui traremos a grande problemática acerca da propagação da pena sob os inocentes filhos das encarceradas. O advento da Lei 13.257/2016 e suas respectivas alterações será suscitado. Para finalizar, Adriana Ancelmo figurará como caso emblemático de abertura de precedente à outras mulheres abarcadas pelas hipóteses legais que possuíam seu direito ao benefício violado. Duas causas judiciais importantes que assim se sucederam também serão abordadas.

A importância deste estudo se dá diante da vontade de reverter o quadro do crescente fenômeno do encarceramento feminino, cuja taxa de aprisionamento sofreu um aumento abrupto de 53,3\% no mundo em dezessete anos e 567\% no Brasil em quatorze anos. O problema não é criminal por si só, mas sim de bases sociopolítico e econômicas patriarcais. Para diminuir a criminalidade, é necessário a aplicação de políticas públicas específicas ao seu gênero, mas anteriormente é imprescindível a compreensão de suas história, perspectiva e realidade. 


\title{
Capítulo I - A Desigualdade de Gênero no Contexto Jurídico- Criminal
}

\begin{abstract}
A formação de nossa atual população penitenciária ${ }^{1}$ é apenas o espelho de enraizada cultura e eventos pretéritos ocorridos no país. Destarte, imprescindível se faz o revolvimento histórico para a compreensão da complexidade por trás do aumento exponencial do encarceramento feminino brasileiro.

O marco consagrado a ser tido como ponto de partida é a transição para o Brasil neoliberal, pois é aí que se encontram os desdobramentos da lógica punitiva implementada nas políticas criminais que hoje tanto encarcera, como será possível constatar ao longo presente capítulo.
\end{abstract}

\subsection{Formação brasileira e questão social: a lógica neoliberal entre capital e trabalho}

No Brasil pós-transição democrática, encontra-se um cenário de dívida externa e interna devido aos projetos desenvolvimentistas da época da Ditadura. Além disso, problemas cambiais e a crise do petróleo também foram fatores de contribuição para a diminuição do crescimento econômico. Não restou outra saída senão os reajustes dos preços, o que gerou a maior inflação de todos os tempos no país. A instabilidade por todos os lados foi característica marcante deste período em questão. Como resultado do descontrole da economia, tem-se mais pobreza e desigualdade. ${ }^{2}$

\footnotetext{
${ }^{1}$ Perfil este que é desenvolvido de forma completa no Capítulo 2.

${ }^{2}$ ALVES, Joseane Duarte Ouro. A criminalização da questão social: uma juventude encarcerada. Juiz de Fora: Universidade Federal de Juiz de Fora. Mestrado em Serviço Social, 2013, p. 47. Disponível em: <http://www.ufjf.br/ppgservicosocial/files/2013/04/joseane.pdf> Acesso em: 13 de mai.2018.
} 
A partir de 1990, então, os presidentes Fernando Collor de Mello e Fernando Henrique Cardoso compraram a ideia neoliberal ${ }^{3}$ sugerida pelo Consenso de Washington ${ }^{4}$. Desta forma, medidas estratégicas, tais quais, programas de privatizações, desestatizações, abertura da economia e entrada de capital transnacional, foram implementadas. ${ }^{5}$ Além disso, a redefinição do papel estatal no que concerne ao âmbito social transferiu de forma abrupta a responsabilidade que era predominantemente pública à sociedade civil.

De acordo com Ana Paula Ornellas Mauriel, o pensamento de Amartya $\operatorname{Sen}^{6}$ foi de grande influência para o discurso capitalista às avessas:

A força de seu argumento está em se posicionar contrariamente à restrição das preocupações igualitárias somente à questão da renda, passando a considerar que a forma de igualdade central ou preponderante é a capacidade igual de funcionar de várias maneiras.

Sua ideia sobre desenvolvimento como liberdade - cuja base está radicada justamente na dissociação entre as dimensões do ter (renda, bem-estar, bens) e do ser/fazer (das capacidades, dos funcionamentos, dos intitulamentos) - permite pensar e construir políticas de desenvolvimento sem necessariamente recorrer a um

\footnotetext{
${ }^{3}$ De forma resumida, o neoliberalismo surge a partir da Segunda Guerra Mundial e é uma tentativa de recuperar os pressupostos do liberalismo econômico do século XVI e XVII. A defesa de um estado mínimo com o objetivo de fazer a economia funcionar sobre as regras do livre mercado trazem grandes crítica ao modelo do Estado do Bem-Estar Social vigente na época.

${ }^{4}$ As ideias neoliberais ganham corpo principalmente na década de 1970 por meio de dois importantes fatores: o fortalecimento da tese de que a economia planificada e Estado interventor seriam prejudiciais à economia diante do colapso do bloco socialista e também da realização do Consenso de Washington em 1989 (evento este no qual houve importante deliberação de três importantes órgãos, Fundo Monetário Internacional, Banco Mundial e Tesouro dos Estados Unidos, acerca de implementação de estratégia para influenciar os países latino-americanos endividados a diminuírem seus gastos). O objetivo era trazer o conceito de diminuição da intervenção do Estado sobre as atividades econômicas em uma tentativa de disseminar a proposta e captar novas adesões.

${ }^{5}$ MIRANDA, Aline Barbosa de; MIRANDA, Gilberto José; VERÍSSIMO, Michele Polline. Ajuste neoliberal e a crise do Estado: necessidade de se retomar a autonomia dos Estados nacionais. Uberlândia: anais do IV Simpósio Internacional: o Estado e as Políticas Educacionais no Tempo Presente, 2008, p. 5. Disponível em: <http://www.simposioestadopoliticas.ufu.br/imagens/ anais/ pdf/AC04.pdf > Acesso em: 14 de mai.2018.

${ }^{6}$ Professor de economia e filosofia do Trinity College da Universidade de Cambridge na Inglaterra que recebeu o Prêmio Nobel de Economia em 1998 diante de sua análise sobre desenvolvimento. Sua originalidade se encontra na perspectiva integrada das esferas econômica, social e política.

O tema aqui em destaque refere-se ao pensamento específico de sua obra "Development as Freedom", Oxford: Oxford University Press, 1999 sobre a expansão da liberdade como meio principal ao desenvolvimento.
} 
planejamento social direto via Estado como no pós-guerra, com o Welfare State.

[...] ele consegue construir um conjunto de ideias em que o centro da análise sobre pobreza e desigualdade não é mais a estrutura, mas sim o indivíduo. ${ }^{7}$

Dentro do paradigma neoliberal, esta é a justificativa perfeita para desmitificar o critério de análise das desvantagens. Assim, o cerne da pobreza e da desigualdade passa a ser a questão das capacidades e escolhas individuais de cada $u^{8}$ e não mais o baixo nível de renda pela questão estrutural em si. Com o intuito de ocultar as contradições do próprio sistema, a modificação do raciocínio traz um novo significado ao papel das políticas sociais. Claramente a adoção de tal entendimento é um descaso perante todas às necessidades e carências da maioria da população brasileira.

Diante desta inversão de valores, a questão social se acirra ainda mais devido a uma restruturação da cadeia produtiva. O emprego de tecnologia como base de sua produção e a qualificação profissional são características deste nova era. Desta forma, o mercado de trabalho é diretamente impactado. Assim, conforme Joseane Duarte Ouro Alves:

As decisões políticas do Estado brasileiro que acompanham este contexto vão ser caracterizadas pela privatização ascendente das suas funções, num desmonte de políticas públicas e na crescente mercantilização dos serviços sociais gerando mais impactos negativos para aqueles sujeitos que sobrevivem da venda de sua força de trabalho. ${ }^{9}$

\footnotetext{
${ }^{7}$ MAURIEL, Ana Paula Ornellas. Combate à pobreza e (des) proteção social: dilemas teóricos das novas políticas sociais. In: Estudos de Política e Teoria Social, $\mathrm{n}^{\circ} 14$ e 15. Rio de Janeiro: Editora UFRJ, 2006. p. 59/60. Disponível em: <https://docs.google.com/file/d/0B0--tS_Kbeq-MmlfeEc 5RkNu Y3M/ edit> Acesso em: 02 de mai.2018.

8 É possível aqui realizar o paralelo com o termo "meritocracia", este tanto utilizado na contemporaneidade. Ou seja, a conquista segundo o merecimento pelo predomínio do conhecimento ou competência, conforme definição do dicionário Aurélio: FERREIRA, Aurélio Buarque de Holanda. Mini Aurélio: O dicionário da língua portuguesa. $6^{\mathrm{a}}$ edição revista e atualizada, $5^{\mathrm{a}}$ impressão. Curitiba: Editora Positivo, 2016.

${ }_{9}^{9}$ ALVES, Joseane Duarte Ouro. Op. cit., p. 50.
} 
Isso corrobora com o entendimento de Marilda Villela Iamamoto, que suscita:

O predomínio do capital fetiche conduz à banalização do humano, à descartabilidade e indiferença perante o outro, o que se encontra na raíz das novas configurações da questão social na era das finanças. Nesta perspectiva, a questão social é mais do que expressões de pobreza, pobreza, miséria e exclusão. Condensa a banalização do humano, que atesta a radicalidade da alienação e invisibilidade do trabalho social - e dos sujeitos que o realizam - na era do capital fetiche. ${ }^{10}$

O fenômeno da "financeirização da economia"11, advindo do neoliberalismo, portanto, explica Emir Sader, produziu resultados negativos profundos ao Brasil. Isso significa que o "Estado ter se tornando refém do capital" 12 tornou o mercado de trabalho seletivo apenas aos tidos como "aptos" e aos outros trabalhadores, restou-lhes a exclusão social dos meios de produção. A solução encontrada ao desemprego foi a informalização do trabalho.

Importante lembrar que estas pessoas à margem da sociedade além de pobres, são também majoritariamente negras, já que o passado do país se ancora em grande período de escravidão. ${ }^{13}$ Isso significa que a esfera de observação deve ser interseccional entre classe e raça.

Mas e a situação das mulheres no capitalismo? É deste ponto que se segue.

${ }^{10}$ IAMAMOTO, Marilda Villela. Serviço social em tempo de capital fetiche: capital financeiro, trabalho e questão social. $7^{\mathrm{a}}$ edição. São Paulo: Cortez, 2012. p. 125. Disponível em: 〈http://www.cortezeditora.com.br/newsite/primeiraspaginas/servico_social_em tempo.pdf $>$ Acesso em: 03 de mai.2018.

${ }^{11}$ SADER, Emir. A construção da hegemonia pós-neoliberal. In: SADER, Emir (org). 10 anos de governos pós-neoliberais no Brasil: Lula e Dilma. São Paulo: Editora Boitempo, 2013. p. 138.

12 Ibid., p. 138. Disponível em: <http://gege.fct.unesp.br/docentes/geo/bernardo/BIBLIOGRAFIA \%20DISCIPLINAS\%20POSGRADUACAO/BERNARDO\%20MANCANO\%20FERNANDES/10_A NOS GOVERNOS.pdf> Acesso em: 03 de mai.2018.

${ }_{13}$ SOUZA, Jessé. Ralé brasileira: quem é e como vive. Belo Horizonte: Editora UFMG, 2009. Disponível em: 〈http://flacso.redelivre.org.br/files/2014/10/1143.pdf〉 Acesso em: 02 de mai.2018. 


\subsection{A questão social sob a perspectiva de gênero}

Diante da exposição do tópico anterior, percebe-se que as reformas neoliberais trouxeram inúmeras consequências ao país, principalmente no que tange à questão social. Acontece que a visão antecedente sobre a relação entre capital e trabalho não abarca as especificidades da realidade feminina. Por isso, a perspectiva feminista introduz o conceito de gênero como categoria de análise.

Importante mencionar que a visão anterior sobre raça e classe foi válido para a elaboração de uma perspectiva interseccional de forma integrada com a questão de gênero.

\subsubsection{A divisão sexual do trabalho e feminização da pobreza}

A mundialização do capital nos anos noventa, além de todas as consequências já enumeradas à população pobre e/ou negra, trouxe mazelas específicas no que tange ao indivíduo na condição de mulher (e sobretudo aquela na condição de mulher negra, como será entendido mais a diante).

O primeiro ponto a ser tratado é a desigualdade existente entre homens e mulheres dentro das relações de trabalho e emprego. É categórico afirmar que a divisão sexual do trabalho advém da construção cultural perante o modelo patriarcal de família. ${ }^{14}$

A separação entre trabalho pertinente a homens e trabalho que concerne às mulheres categorizou e hierarquizou as tarefas. É possível perceber o grau de importância e prestígio inferiores nas esferas atribuídas ao gênero feminino,

\footnotetext{
${ }^{14}$ HIRATA, Helena; KERGOAT, Danièle. Mercado de trabalho e gênero: comparações internacionais. In: COSTA, Albertina de Oliveira; SORJ, Bila; BRUSCHINI, Cristina; HIRATA, Helena (orgs). Divisão sexual do trabalho profissional e doméstico: Brasil, França e Japão. Rio de Janeiro: Editora FGV, 2008. p. 267.
} 
quais sejam, as tarefas domésticas e a maternidade. Portanto, a valorização social e econômica se dá somente das funções determinadas como masculinas. ${ }^{15}$

De acordo com Ramos, a mulher já começa de um patamar de vulnerabilidade e desprivilégio a partir de um estigma de inferioridade no mercado de trabalho. ${ }^{16}$

Recente pesquisa da Organização das Nações Unidas, de título "Transformando promessas em ações: igualdade de gênero na agenda 2030 para o desenvolvimento sustentável" ${ }^{17}$, demonstra em complexo relatório o desenvolvimento global de mulheres em múltiplos campos de atuação. Infelizmente, o resultado não é nada favorável, pois constata-se que o gênero feminino é mais pobre, sofre mais discriminação e passa mais fome do que o masculino. As dificuldades de acesso ao mercado de trabalho, bem como as oportunidades financeiras a elas disponíveis são os motivos apontados ao longo da pesquisa.

$\mathrm{Na}$ melhor das perspectivas, mesmo quando a mulher consegue um emprego para se subsistir, ainda assim, ela, frequentemente, recebe menor salário do que o homem. Um exemplo brasileiro interessante a se levantar em pauta é a Tabela 1 do relatório "Desenvolvimento humano para além das médias" de 2017, o qual demonstra o quadro de renda média entre mulheres e homens nos anos de 2000 e 2010. Os dados constados são os seguintes: A renda da mulher no ano 2000 era $\mathrm{R} \$ 939,10$, enquanto do homem $\mathrm{R} \$ 1.422,30$. Dez

\footnotetext{
${ }^{15}$ Ibid., p. 31.

${ }^{16}$ RAMOS, Luciana de Souza. Por amor ou pela dor? Um olhar feminista sobre o encarceramento por tráfico de drogas. Brasília: Dissertação de Mestrado. Faculdade de Direito da Universidade de Brasília. 2012, p. 105. Disponível em: <http://repositorio.unb.br/bitstream/10482/13758/1/2012_Lucianade SouzaRamos.pdf> Acesso em: 02 de mai.2018.

17 Relatório Transformando promessas em ações: igualdade de gênero na agenda 2030 para o desenvolvimento sustentável. Grupo de trabalho da sociedade civil para agenda 2030. Brasil: junho/2017. Disponível em: <http://actionaid.org.br/wp-content/files_mf/1499785232Relatorio_sintese_v2_23 jun.pdf> Acesso em: 02 de mai.2018.
} 
anos mais tarde, ainda há significativo nível de desigualdade, no qual a mulher recebe $\mathrm{R} \$ 1.059,30$ e o homem $\mathrm{R} \$ 1.470,73 .^{18}$

Outro fator de relevância é a responsabilidade majoritária das mulheres no que concerne aos afazeres domésticos. Há grande disparidade entre os gêneros: em 2017, por exemplo, enquanto as mulheres dedicaram a média de 20,9 horas por semana nestas atividades, os homens apenas 10,8 horas, conforme dados da Pesquisa Nacional por Amostra de Domicílios Contínua 2017 (PNAD Contínua). ${ }^{19}$

Por fim, a maternidade é um aspecto que também não pode ser esquecido de menção, pois a gravidez e as obrigações maternais para com os filhos é algo que afasta as mulheres do mercado de trabalho de fato. Existe descriminação de gênero sim ao se pensar em tópicos como licença gestacional, licença maternidade, benefício previdenciário do salário-maternidade, entre outras proteções e direitos relacionados à reprodução e aos filhos que homens não possuem. ${ }^{20}$ Por isso, a interpretação dos empregadores é que contratar trabalhadores do gênero masculino geram prejuízos menores do que a contratação daquelas do gênero feminino. ${ }^{21}$

Diante de toda a exposição sobre divisão sexual do trabalho, conclui-se, portanto, que o índice do empobrecimento da mulher é maior do que o do homem. Segundo Maria Salet Novellino, a pobreza vem adquirindo um perfil predominantemente feminino, caracterizando, desta forma, um problema de

\footnotetext{
${ }^{18}$ PNUD, IPEA, FJP. Desenvolvimento humano para além das médias. Brasília, 2017. Disponível em: <http://www.br.undp.org/content/dam/brazil/docs/IDH/desenvolvimento-alem-das-medias.pdf> Acesso em: 02 de mai.2018.

${ }^{19}$ IBGE. Pesquisa Nacional por Amostra de Domicílio Contínua (PNAD). Brasil: 2017. Disponível em:<https://agenciadenoticias.ibge.gov.br/media/com mediaibge/arquivos/4581438d7e04a73aede241d 3327e4187.pdf> Acesso em: 03 de mai.2018.

${ }^{20}$ MARTINS, Sérgio Pinto. Comentários à CLT. $8^{\mathrm{a}}$ edição. São Paulo: Atlas, 2004, p. 1184.

${ }^{21}$ TEIXEIRA, Daniel Viana. Desigualdade de gênero: sobre garantias e responsabilidades sociais de homens e mulheres. São Paulo: Revista Direito GV, Jan-Jun 2010. Disponível em: <http://www.scielo.br/pdf/rdgv/v6n1/12.pdf> Acesso em: 04 de mai.2018.
} 
gênero específico ${ }^{22}$. A estadunidense Diane Pierce, em 1978, intitulou este fenômeno como "feminização da pobreza". ${ }^{23}$

Como foi possível perceber, o mercado de trabalho formal "se apresenta para a maioria das mulheres como um lugar que reflete as discriminações sexistas, com baixos salários, trabalhos precarizados e de baixo prestígio". ${ }^{24}$ Logo, a dificuldade de inserção e oportunidade de emprego somado às condições sociopolítico e econômicas desenvolvidas no tópico antecedente (crise econômica, má distribuição de renda, desigualdade social, pobreza e desemprego) foram fatores de imensa contribuição para o crescimento da economia denominada por informal, comandada em sua grande maioria pelo gênero feminino.

No que se pesa em relação à economia informal, de acordo com o entendimento de Arnaldo Bagnasco:

A economia não registrada, ou oculta, torna-se um objeto indefinido. Sabemos que é estar interessado em uma vasta gama de coisas diferentes: mercados ilegais, bicos e serões, a economia pública e a economia doméstica, fora do mercado, no setor público e o "faça você mesmo", e assim por diante. Esses fenômenos são diferentes um do outro de um modo tão vasto que tudo o que podemos fazer para reuni-los conceitualmente é rotulá-los com um termo negativo, não pelo que são, mas pelo que não são. [...] podemos considerá-los como tipos ou aspectos que deixam de corresponder a uma certa forma de economia percebida por nós como sendo normal. ${ }^{25}$

É possível constatar, portanto, que nesta categoria econômica subjacente existe um limite turvo entre lícito e ilícito. No caso da mulher, a atividade ilícita

\footnotetext{
${ }^{22}$ NOVELLINO, Maria Salet. Os estudos sobre a femininização da pobreza e políticas públicas para mulheres. São Paulo: Anais do XIV Encontro Nacional de Estudos Populacionais: 2004. Disponível em: $<$ http://www.abep.nepo.unicamp.br/docs/anais/outros/FamPolPublicas/SaletNovellino.pdf $>$ Acesso em: 03 de mai.2018.

${ }^{23}$ PIERCE, Diane. The feminization of poverty: women, work and welfare. Washington: Urban and Social Change Review, 1978. p. 28-36.

${ }^{24}$ RAMOS, Luciana de Souza. Op. Cit., p. 8.

${ }^{25}$ BAGNASCO. Arnaldo. A economia informal, vol. 18, no 2, Porto Alegre: Ensaios FEE, 1997. p. 14/15. Disponível em: <https://revistas.fee.tche.br/index.php/ensaios/article/view/1896/2270> Acesso em: 07 de mai. 2018.
} 
do tráfico de drogas aparece como estratégia de sobrevivência para prover o sustento próprio e dos filhos.

\subsection{A lógica punitiva da política de drogas e o encarceramento feminino em massa}

O encarceramento em massa possui relação direta com a implementação da política de "Guerra às Drogas" pelos Estados Unidos ao longo das últimas três décadas. Sua característica principal parte da premissa do aprisionamento seletivo e é utilizado como instrumento de controle social da população historicamente declarada como inimiga interna, ou seja, homens negros jovens. ${ }^{26}$ Este modelo de "lei e ordem" foi reproduzido por diversos países da América Latina, incluindo o Brasil.

No que concerne ao território brasileiro, a Lei de Drogas, formalmente conhecida por Lei 11.343/2006, é o maior exemplo afirmativo desta logística punitiva. A ideologia de despenalização das condutas de uso e o enrijecimento da pena diante do crime de tráfico de entorpecentes trouxe contornos discrepantes. Aumentou-se a pena base do artigo 33 e, ainda, o crime do tráfico foi equiparado aos crimes hediondos advindo da Lei 8.072/1990. Estes fatores reforçaram ainda mais as mazelas sociais e a seletividade do sistema.

\footnotetext{
${ }^{26}$ No que tange ao direito penal, utiliza-se o crime como ferramenta de seletividade penal a partir da criação de estereótipos criminalizáveis de determinados indivíduos. Alessandro Baratta explica que o sistema penal nada mais é do que um modelo de etiquetamento (Labelling Approach) e é desta forma que o fenômeno da criminalização da pobreza ocorre.

A exclusão social, fruto da desigualdade, somada ao perfil de periculosidade cria a estrutura do mal cósmico e todos aqueles encaixados na referida categoria são caracterizadas como "inimigo público". A lógica econômica utiliza o pânico social e o medo como estratégia, pois a súplica da população contra a impunidade legitima o discurso do poder punitivo. Na tentativa de controle social e promoção do bemestar coletivo, políticas criminais cada vez mais repressivas são aplicadas para a suposta garantia de ordem e segurança pública. A consequência disso é o encarceramento em massa destas pessoas.
} 
Acontece que este cenário é ainda mais dramático no que tange às mulheres, pois as questões sociais e a realidade criminal feminina são completamente desprezadas pela Lei de Drogas.

Como desenvolvido no tópico 1.2.1, a divisão sexual do trabalho e a consequente feminização da pobreza são aspectos determinantes para a introdução da mulher na atividade ilícita do tráfico de drogas. Este quadro se reproduz não só no Brasil, mas como em todo território latino-americano.

A realidade socioeconômica da mulher fez com que o mercado do tráfico de drogas absorvesse a mão de obra feminina de forma avassaladora. Esta enxergou no tráfico de drogas uma oportunidade de trabalho com menos obstáculos do que o mercado formal e também a vantagem da agilidade do retorno financeiro.

Além disso, outro benefício a ser mencionado seria a conciliação da renda para sua subsistência e a de seus filhos (papel produtivo) aos afazeres domésticos e maternidade (papel social) ${ }^{27}$. Segundo Torres Angarita, é importante, portanto, que diante de um panorama de feminização da pobreza e exercício de papel social da mulher, o fator econômico seja compreendido juntamente à questão de gênero. ${ }^{28}$

A decisão da mulher por participação em atividades criminosas é, assim, fruto da vulnerabilidade de gênero a qual ela está intrinsecamente submetida ${ }^{29}$.

Acontece que dentro o tráfico perpetua-se a desigualdade de gênero do mercado de trabalho formal. A inserção da mulher continua em baixos níveis

\footnotetext{
${ }^{27}$ Esse fenômeno se intensifica ainda mais quando a mulher é a chefe da família e não conta com a ajuda monetária de um parceiro para cuidar da família, da casa e na divisão das despesas.

28 ANGARITA, Torres. Drogas y Criminalidad Femenina en Ecuador: el amor como un fator explicativo en la experiencia de las mulas. Programa de maestria em ciencias sociales. Mención estudios de género y desarrollo, Equador: Facultad Latinoamericana de Ciencias Sociales, 2007. p. 88.

${ }^{29}$ SOUZA, Simone Brandão. Criminalidade Feminina: trajetórias e confluências na fala de presas do Talavera Bruce. Rio de Janeiro: Dissertação de Mestrado. Escola Nacional de Ciências Estatísticas. Universidade Federal do Rio de Janeiro, Rio de Janeiro, 2005. p. 18. Disponível em: 〈http://www.observatoriodeseguranca.org/files/dv33_artigo2.pdf> Acesso em: 08 de mai. 2018.
} 
hierárquicos, no quais elas atuam em posição subalternas, dentro da própria lógica do patriarcado.

O papel de empacotar, guardar e transportar são as modalidades de participação feminina com maior presença no tráfico. Maria Juruena Moura, em sua pesquisa "Porta fechada, vida dilacera - mulher, tráfico de drogas e prisão: estudo realizado no presídio feminino do Ceará" constatou que:

$81,4 \%$ das reclusas confirmaram trabalhar em postos de menor relevância, como mula, vendedora retalhista e pião, o que torna perceptível a descriminação de gênero também no trabalho do tráfico de drogas. Ressalto que as mulheres, embora em postos subsidiários, aumentaram significativamente sua participação no negócio do tráfico. Segundo dados da pesquisa, 56,1\% dessas mulheres concentram-se na função de mula, avião e pião, enquanto $18,7 \%$ atuam como vendedora retalhista. Saliento que o transporte de drogas não ocorre só fora do presídio, pois uma parcela dessas mulheres é presa ao entrar no presídio, levando droga na vagina, barra de sabão, salto alto, frutas, etc, para os maridos, companheiros, namorados, irmãos, filhos, amigos, possibilitando a que estes façam o uso e venda de tal produto no interior do presídio, estabelecendo, assim, uma micro comercialização. ${ }^{30}$

A participação em tarefas menos complexas, em postos de menos prestígio, pagando menor capital e de maior risco de captura são exemplos de como as mulheres são utilizadas como figuras meramente descartáveis no comércio de drogas. ${ }^{31}$

O fato das mulheres ocuparem posições subalternas significa que há maiores chances de estarem presentes na hora do flagrante e, por consequência, na seleção penal ao combate ao tráfico.

Larissa Urruth Pereira e Gustavo Noronha Ávila sustentam, portanto, a grande crítica à Lei de Drogas:

\footnotetext{
${ }^{30}$ MOURA, Maria Jurena. Porta fechada, vida dilacera - mulher, tráfico de drogas e prisão: estudo realizado no presídio feminino do Ceará. Ceará: Dissertação de Mestrado. Programa de Pós-Graduação em Políticas Públicas e Sociedade. Universidade Estadual do Ceará, Ceará, 2005. Disponível em: <http://www.uece.br/politicasuece/dmdocuments/dissertacao_juruena_moura.pdf $>$ Acesso em: 09 de mai. 2018.

${ }^{31}$ RAMOS, Luciana de Souza. Op. cit., p. 56.
} 
As grandes figuras do tráfico de drogas, os grandes "patrões" desse comércio, não acabam nas penitenciárias, esses possuem recursos o suficiente para não se submeterem ao sistema penal. O tráfico que é punido, é o tráfico da subsistência, é o tráfico da mãe, que para sustentar os filhos se submete à lei paralela das drogas, é o tráfico da esposa que leva entorpecentes para o presídio, para manter a dignidade do marido recluso. São os pequenos que figuram no banco dos réus, enquanto o problema que tanto a sociedade quer combater, por escolha dessa mesma sociedade, permanece em liberdade. ${ }^{32}$

É por isso que se vive uma realidade na qual o crime que mais encarcera mulheres no Brasil é o tipo penal de tráfico de drogas. A porcentagem de mulheres é de $68 \%$ (enquanto a porcentagem dos homens é de apenas 26\%), segundo dados do Levantamento Nacional de Informação Penitenciária (InfoPen - Mulheres) de junho de 2014. ${ }^{33}$ Este é um número muito alto e atua como um dos fatores explicativos do fenômeno crescente do encarceramento feminino nacional (o aumento foi de $567 \%$ em quatorze anos) ${ }^{34}$ e também no mundo (o aumento foi $53,3 \%$ em dezessete anos), ${ }^{35}$ sendo melhor desenvolvido nos tópicos $2.1,2.2$ e 2.3 do próximo capítulo.

\subsection{A solução ao problema do superencarceramento feminino}

Diante de todos os fatos supracitados, entende-se que a questão penitenciária engloba um fator maior chamado questão criminal, que por sua

\footnotetext{
32 PEREIRA, Larissa Urruth; ÁVILA, Gustavo Noronha de. Política de drogas e aprisionamento feminino - o tráfico e o uso na lei de drogas. Rio Grande do Sul: Revistas da Pontifícia Universidade Católica do Rio Grande do Sul. Ciências Criminais. E-book. p. 9. Disponível em: $<$ http://ebooks.pucrs.br/edipucrs/anais/cienciascriminais/IV/46.pdf $>$ Acesso em: 03 de mai.2018.

${ }_{33}$ BRASIL. Dados Consolidados. Levantamento Nacional de Informações Penitenciárias - InfoPen Mulheres. Departamento Penitenciário Nacional. Ministério da Justiça. Junho/2014. p. 29. Disponível em: $<$ http://www.justica.gov.br/news/estudo-traca-perfil-da-populacao-penitenciaria-feminina-nobrasil/relatorio-infopen-mulheres.pdf $>$ Acesso em: 04 de mai.2018.

${ }^{34}$ Ibid., p. 10. Disponível em: <http://www.justica.gov.br/news/estudo-traca-perfil-da-populacaopenitenciaria-feminina-no-brasil/relatorio-infopen-mulheres.pdf > Acesso em: 04 de mai.2018.

${ }_{35}^{35}$ ICRP. World Female Imprisonment List, fourth edition. World Prison Brief. Londres: Birkbeck University of London, 2017. p. 13. Disponível em: <http://www.prisonstudies.org/sites/default/files/ resources/downloads/world_female_prison_4th_edn_v4_web.pdf $>$ Acesso em: 04 de mai. 2018.
} 
vez, faz parte também de outra esfera ainda mais ampla: as estruturas sociopolítico e econômicas. Ou seja, é necessário o planejamento perante a mudança das estruturas da sociedade como um todo.

Acontece que as estruturas socias não são fáceis de serem mudadas repentinamente, $\log$, a solução ao encarceramento em massa feminino deve focar em soluções ao nosso alcance.

A partir do momento que adquirimos consciência de que a guerra às drogas é uma guerra contra as mulheres, sobretudo às mulheres negras e de baixa renda, entendemos que a medida mais urgente a se tomar é a discussão e reformulação da política de drogas, assim como a implementação de políticas públicas voltadas a este perfil.

É imprescindível que medidas sejam repensadas diante da realidade e perspectiva femininas e, assim, o fenômeno do encarceramento em massa deste gênero seja diminuído ou, no mínimo, freado. Para isto, o próximo capítulo trará um apanhado de informações sobre estas mulheres, pois conhece-las a fundo, nos dão a perspectiva sobre suas realidades e histórias. 


\section{Capítulo II - O Perfil da População Prisional Feminina Brasileira e o Fenômeno do Superencarceramento}

"Depósito de seres humanos"36 pode ser compreendido como a definição mais adequada quando se trata do sistema penitenciário brasileiro, padecedor este de inúmeras carências e deficiências estruturais. A insalubridade dos locais, a superlotação carcerária, a precariedade com relação às necessidades dos presos e a violência institucional impregnada são alguns exemplos a serem citados.

Agora, no tocante à perspectiva específica do encarceramento feminino, essas dificuldades são ainda mais alarmantes, pois, além da falta do Estado com relação as condições comuns da população carcerária em geral, encontram-se ausentes medidas que abarquem a questão de gênero em si, como será explicitado mais para frente. Aspectos do patriarcado e violência contra a mulher imperam no próprio Direito e nas instituições prisionais em muitos aspectos. A mulher é completamente esquecida dentro de um sistema criado, desenvolvido e voltado para homens.

Desta forma, o objetivo do presente capítulo é traçar o perfil das mulheres presas no Brasil a fim de destacar suas respectivas necessidades, assim como a realidade por elas vividas. O parâmetro entre necessidade e realidade será englobado por um levantamento das legislações que possuem recorte de gênero que, teoricamente, deveriam ampará-las, mas caem no esquecimento e revelam a invisibilidade destas "mulheres da máquina do abandono". ${ }^{37}$

\footnotetext{
${ }^{36}$ OEA, Comissão de Direitos Humanos, Relatório sobre a situação dos direitos humanos no Brasil, 1996. Disponível em: 〈http://www.oas.org/main/portuguese/> e ONU, Comissão de Direitos Humanos, Relatório sobre a Tortura no Brasil, 1997. Disponível em: 〈http://www.global.org.br/portuguese/arquivos/tortura1.pdf> Acesso em: 04 de mai.2018.

${ }^{37}$ DINIZ, Debora. Cadeia - Relatos sobre mulheres. 2a edição. Sinopse. Rio de Janeiro: Civilização Brasileira, 2016.
} 


\subsection{Dados gerais}

Em setembro de 2017, o quarto relatório do World Female Imprisonment List $^{38}$, produzido pelo Institute of Criminal Policy Research da Universidade de Londres, demonstrou que mais de $714 \mathrm{mil}^{39}$ pessoas do gênero feminino encontram-se encarceradas ${ }^{40}$ em mais de 221 sistemas prisionais ao redor do mundo, conforme tabela 1:

Tabela 1 - População carcerária feminina (resumo por continente)

\begin{tabular}{|l|c|c|c|}
\hline & $\begin{array}{c}\text { Female prison } \\
\text { population total } \\
\text { (latest available } \\
\text { to } 30.9 .2017)\end{array}$ & $\begin{array}{c}\text { Women/girls as } \\
\text { percentage of total } \\
\text { prison population }\end{array}$ & $\begin{array}{c}\text { Female prison } \\
\text { population rate } \\
\text { (per 100,000 of } \\
\text { general population) }\end{array}$ \\
\hline AFRICA & 35,606 & $3.4 \%$ & 3.2 \\
\hline AMERICAS & 308,293 & $8.4 \%$ & 31.4 \\
\hline ASIA & 263,571 & $6.7 \%$ & 6.2 \\
\hline EUROPE & 102,397 & $6.1 \%$ & 12.1 \\
\hline OCEANIA & 4,550 & $7.4 \%$ & 11.3 \\
\hline WORLD & 714,417 & $6.9 \%$ & 9.9 \\
\hline
\end{tabular}

A situação prisional feminina no mundo tem crescido assustadoramente. Segundo a referida pesquisa, no ano 2000 o número era de 466 mil e em 2017 passou para 714 mil. O aumento, então, pode ser expressado em 53,3\%, de acordo com a tabela 2:

\footnotetext{
${ }^{38}$ ICRP. Op. cit., p. 13. Disponível em: <http://www.prisonstudies.org/sites/default/files/resources/ downloads/world_female_prison_4th_edn_v4_web.pdf > Acesso em: 04 de mai.2018.

${ }_{39}$ Vale sublinhar, entretanto, que as estatísticas de Cuba, Eritreia, Coreia do Norte, Somália e Uzbequistão foram tidas, por eles próprios, como "indisponíveis no momento" (além disso, a China trouxe dados incompletos). Desta forma, existem lacunas e este número não representa de fato a totalidade, pois é ainda maior.

${ }^{40} \mathrm{O}$ encarceramento aqui referido refere-se a prisão como privativa de liberdade no geral, independente do tipo, portanto, abarca não só aquelas decorrentes de sentença condenatória em definitivo, mas também a provisória e a preventiva.
} 
Tabela 2 - População carcerária feminina (mudanças desde o ano 2000)

\begin{tabular}{|l|c|c|c|c|}
\hline & $\begin{array}{c}\text { Estimated female } \\
\text { prison population } \\
\text { total at about 2000 }\end{array}$ & $\begin{array}{c}\text { Latest available } \\
\text { female prison } \\
\text { population total } \\
\text { (to } 30.9 .2017)\end{array}$ & $\begin{array}{c}\text { Change in } \\
\text { female prison } \\
\text { population total } \\
\text { since about 2000 }\end{array}$ & $\begin{array}{c}\text { Change in } \\
\text { general population } \\
\text { mid-2000 to mid-2016 } \\
\text { (United Nations) }\end{array}$ \\
\hline AFRICA & 25,000 & 35,606 & $+42.4 \%$ & $+49.4 \%$ \\
\hline AMERICAS & 196,300 & 308,293 & $+57.1 \%$ & $+19.1 \%$ \\
\hline ASIA & 143,800 & 263,571 & $+83.3 \%$ & $+19.4 \%$ \\
\hline EUROPE & 98,900 & 102,397 & $+3.5 \%$ & $+3.7 \%$ \\
\hline OCEANIA & 1,900 & 4,550 & $+139.5 \%$ & $+28.4 \%$ \\
\hline WORLD & 465,900 & 714,417 & $+53.3 \%$ & $+21.3 \%$ \\
\hline
\end{tabular}

O que é peculiar, entretanto, é que os próprios pesquisadores do Instituto explicam que este fenômeno não pode ser argumentado em comparação à proporção do crescimento populacional global ou do crescimento do número total de prisioneiros. Isto, pois, mundialmente falando, a população total cresceu apenas $21 \%$ e a população carcerária masculina somente $20 \%$ neste meio tempo abarcado. Logo, a explicação não é meramente matemática.

No que se refere ao Brasil em questão, este possui mais um recorde para se envergonhar: é o quarto país no mundo que mais encarcera mulheres (recentemente ultrapassou a Tailândia no ranking), ficando atrás agora apenas dos Estados Unidos, China e Rússia, como pode ser examinado na Tabela 3 a seguir (lacuna 1): 
Tabela 3 - Informações prisionais dos doze países com maior população prisional feminina do mundo (2017)

\begin{tabular}{|c|c|c|c|}
\hline País & $\begin{array}{c}\text { População } \\
\text { prisional feminina }\end{array}$ & $\begin{array}{c}\text { Porcentagem da } \\
\text { população } \\
\text { prisional total }\end{array}$ & $\begin{array}{c}\text { Taxa de } \\
\text { aprisionamento } \\
\text { (por 100 mil } \\
\text { habitantes) }\end{array}$ \\
\hline Estados Unidos & 211.870 & 9,8 & 65,7 \\
\hline China & 107.131 & 6,5 & 7,6 \\
\hline Rússia & 48.478 & 7,9 & 33,5 \\
\hline Brasil & 44.700 & 6,9 & 21,7 \\
\hline Tailândia & 41.119 & 13,3 & 60,7 \\
\hline Índia & 17.834 & 4,3 & 1,4 \\
\hline Filipinas & 12.658 & 8,9 & 12,4 \\
\hline Vietnã & 11.644 & 10,1 & 4,3 \\
\hline Indonésia & 11.465 & 5,5 & 8,8 \\
\hline México & 10.832 & 5,2 & 17,9 \\
\hline Myanmar & 9.807 & 12,3 & 12,1 \\
\hline Turquia & 9.708 & 4,3 & \\
\hline
\end{tabular}

*Dado incompleto: referente somente às presas condenadas.

Fonte: Elaboração própria a partir dos últimos dados disponíveis de cada país com base no World Female Imprionment List de 2017 (baseada na tabela já existente no InfoPen Mulheres 2014, porém atualizada).

Diante desta tabela é possível observar também a proporção de presas comparado à população prisional total (lacuna 2). Ou seja, a porcentagem que a população prisional feminina daquele país representa no número final de pessoas presas no mundo. Segundo dados da referente pesquisa:

Em $80 \%$ dos países do mundo as mulheres representam entre 2 e $9 \%$ da população prisional total. Em Hong Kong (China), país em que as mulheres representam o maior contingente, elas compõem $20,8 \%$ da população total privada de liberdade. No Brasil, as mulheres compõem $6,9 \%$ do total, situando o país dentro da margem projetada pelo instituto. ${ }^{41}$

${ }^{41}$ BRASIL. Dados Consolidados. Levantamento Nacional de Informações Penitenciárias - InfoPen Mulheres. Departamento Penitenciário Nacional. Ministério da Justiça, Junho/2014 (porém com dados atualizados do World Female Imprisonment List de 2017). p. 9. Disponíveis em: <http://www.justica.gov.br/news/estudo-traca-perfil-da-populacao-penitenciaria-feminina-no-brasil/ relatorio-infopen-mulheres.pdf $>$ e $\quad$ http://www.prisonstudies.org/sites/default/files/resources /downloads/world_female_prison_4th_edn_v4_web.pdf $>$ Acessos em: 10 de mai.2018. 
Ainda em tempo, a Tabela 3 remete a mais um dado importante: a taxa de aprisionamento (lacuna 3). Esta indica o número de mulheres presas para cada 100 mil habitantes da população nacional. Sua relevância se dá para fins comparativos, tendo em vista as variações consideráveis de cada país, como por exemplo, a densidade demográfica. Assim, é importante fazer o cálculo proporcional para a configuração de uma padronagem perante a coleta de dados. Inclusive, no que tange ao caso brasileiro, por exemplo, aponta-se o seguinte:

\begin{abstract}
O Brasil figura na décima nona posição mundial, com uma taxa de 21,7 mulheres presas a cada 100 mil habitantes, ficando atrás dos Estados Unidos (65,7\%), Tailândia $(60,7 \%)$, El Salvador $(58,4 \%)$, Turcomenistão (38,2\%), Seychelles (34,8\%), Rússia $(33,5 \%)$, Guiana Francesa (32,4\%), Macau (China) (31,3\%), Ruanda (29,6\%), Groelândia (28,5\%), Samoa Americana $(27,3 \%)$, Virgin Is. (UK) (25,0\%), Guam (EUA) (24,3\%), Taiwan $(23,9 \%)$, Hong Kong (China) (23,9\%), Antígua e Barbuda (23,7\%), Belarus $(23,5 \%)$, Singapura $(22,3 \%)$ e Laos $(21,8 \%){ }^{42}$
\end{abstract}

\title{
2.2. Dados no Brasil
}

Depois de uma análise ampla abrangendo níveis mundiais de mulheres encarceradas, será dado prosseguimento ao levantamento de informações perante dados nacionais mais específicos e palpáveis.

Segundo o último relatório do World Female Imprisonment List de setembro de 2017, o Brasil é um dos países em destaque com o crescimento acentuado da privação da liberdade de pessoas do gênero feminino. Desde o ano 2000 , este número aumentou 4,5 vezes. Isto também pode ser comprovado pela pesquisa Levantamento Nacional de Informações Penitenciárias (InfoPen Mulheres) de junho de 2014, último relatório existente o país perante a

\footnotetext{
42 Ibid., p. 9. Disponíveis em: <http://www.justica.gov.br/news/estudo-traca-perfil-da-populacaopenitenciaria-feminina-no-brasil/relatorio-infopen-mulheres.pdf $\rangle$ e $\langle$ http://www.prisonstudies.org/ sites/default/files/resources/downloads/world_female_prison_4th_edn_v4_web.pdf $>$ Acessos em: 10 de mai.2018.
} 
disponibilidade de informações com recorte de gênero sobre o tema, como pode ser visto nos Gráficos 1 e 2:

\section{Gráfico 1 - Evolução da população de mulheres no sistema penitenciário brasileiro de 2000 a 2014}

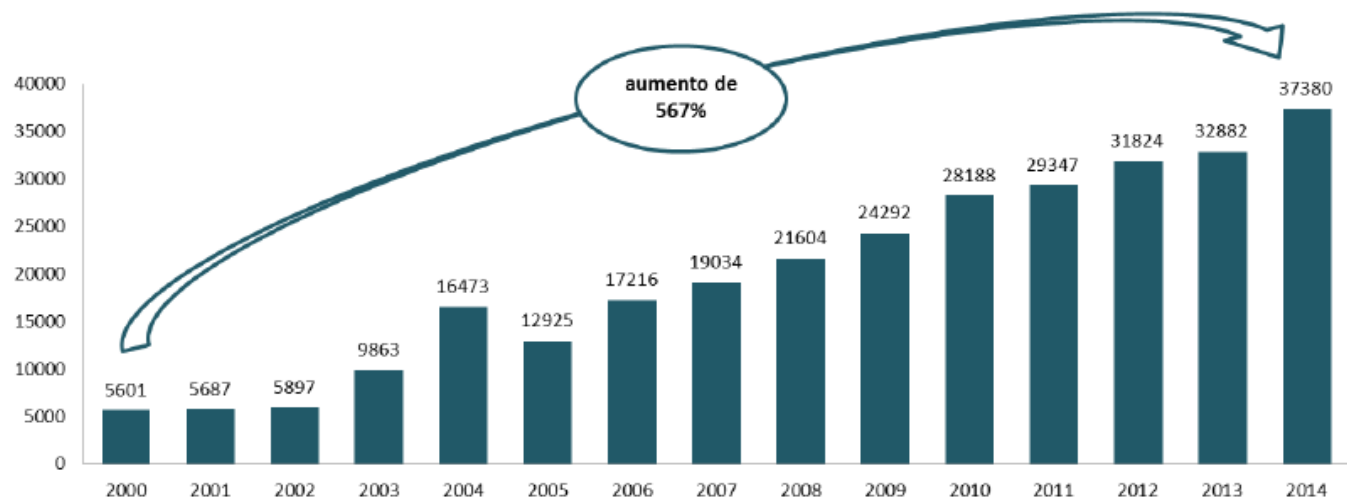

Gráfico 2 - Evolução da população prisional brasileira segundo o gênero de 2000 a 2014

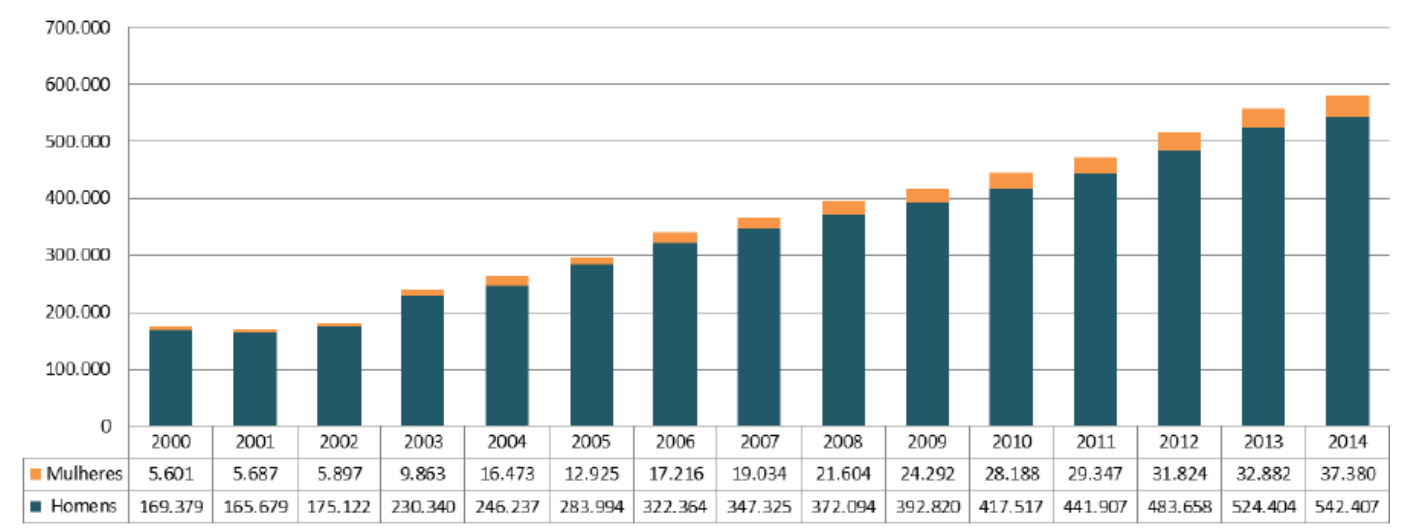

Desta forma, conforme retirado do próprio relatório:

Em que pese a expressiva participação de homens no contingente total de pessoas privadas de liberdade no país, é possível afirmar que a população absoluta de mulheres encarceradas no sistema penitenciário cresceu 567\% entre os anos de 2000 a 2014, chegando ao patamar de 37.380 mulheres, conforme expresso na Gráfico 1. Já a população de homens encarcerados cresceu $220 \%$ no mesmo 
período, seguindo a tendência geral de aumento do encarceramento no Brasil. Se em 2000 as mulheres representavam 3,2\% da população prisional, em 2014 elas passaram a representar 6,4\% do total encarcerado. ${ }^{43}$

Outro dado importante a ser mencionado é a taxa de aprisionamento por 100 mil habitantes (Gráfico 3). "Enquanto a taxa total de aprisionamento aumentou $119 \%$ entre 2000 e 2014, a taxa de aprisionamento de mulheres aumentou $460 \%$ no período, saltando de 6,5 mulheres presas para cada 100 mil mulheres em 2000 para 36,4 mulheres em 2014. "44

Gráfico 3 - Evolução da taxa de aprisionamento por 100 mil habitantes no Brasil de 2000 a 2014

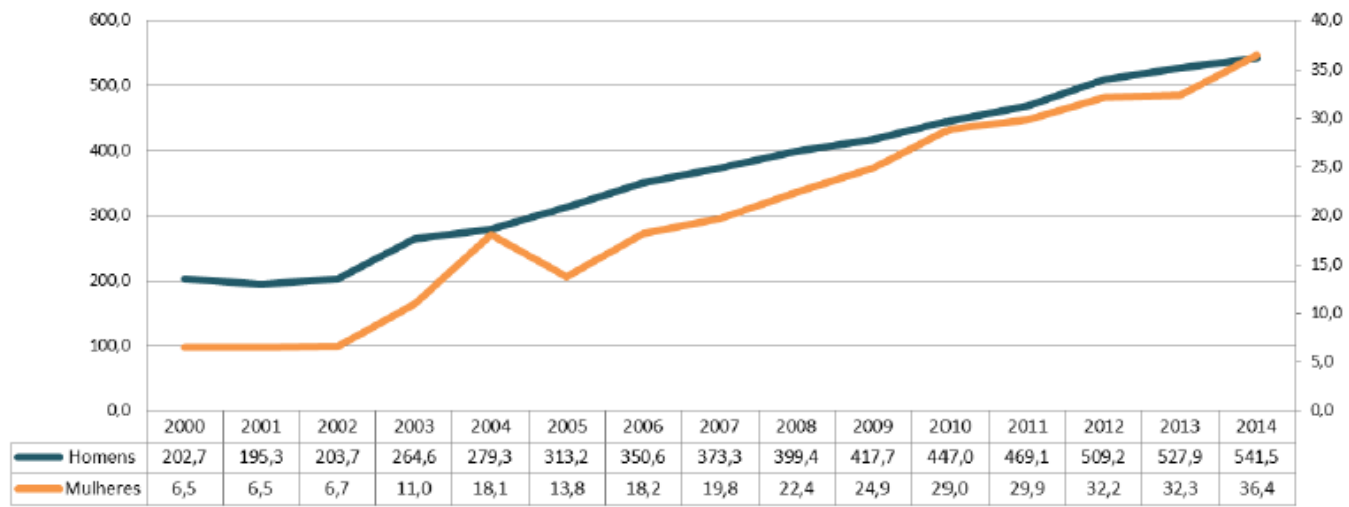

\subsection{Perfil das mulheres encarceradas no Brasil}

Depois desta breve exposição numerológica, pressupõe-se que a população carcerária feminina está crescendo em um compasso descontrolado. A solução para este impasse talvez comece na compreensão de quem sejam estas mulheres e os motivos que levam-nas a cometer os crimes para que se possa

\footnotetext{
${ }^{43}$ BRASIL. Dados Consolidados. Op. cit., p. 10. Disponível em: <http://www.justica.gov.br/news/ estudo-traca-perfil-da-populacao-penitenciaria-feminina-no-brasil/relatorio-infopen-mulheres.pdf $>$ Acesso em: 04 de mai.2018.

44 Ibid., p. 11. Disponível em: <http://www.justica.gov.br/news/estudo-traca-perfil-da-populacaopenitenciaria-feminina-no-brasil/relatorio-infopen-mulheres.pdf $>$ Acesso em: 04 de mai.2018.
} 
pensar em qualquer tipo de medida que leve a redução do encarceramento, como veremos a seguir.

Gráfico 4 - Faixa etária das mulheres privadas de liberdade no Brasil

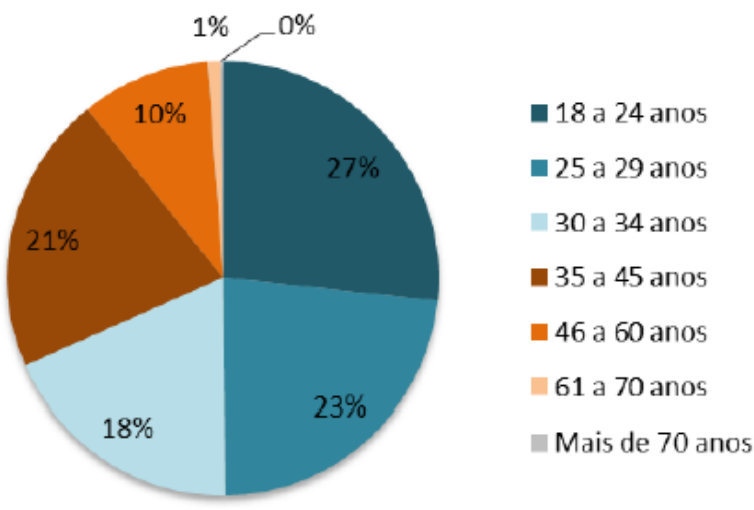

Gráfico 5 - Raça, cor ou etnia das mulheres privadas de liberdade no Brasil

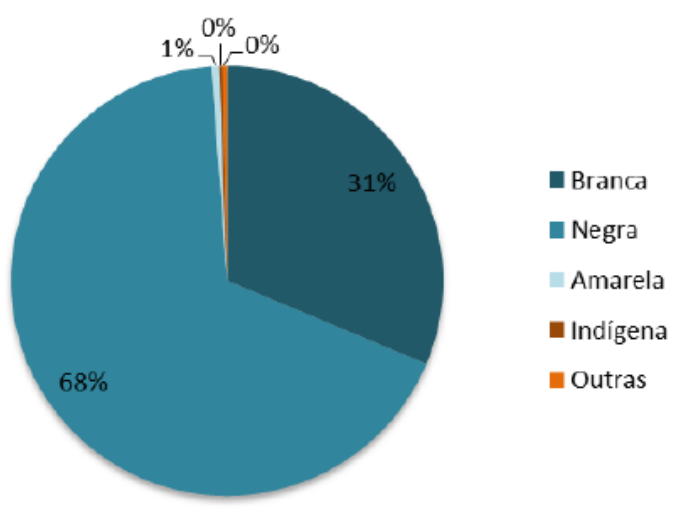


Gráfico 6 - Estado civil das mulheres privadas de liberdade no Brasil

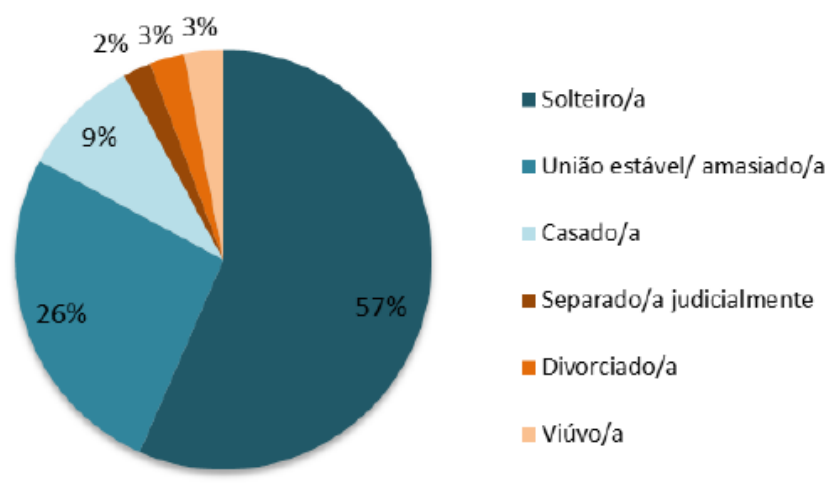

Gráfico 7 - Escolaridade das mulheres privadas de liberdade no Brasil

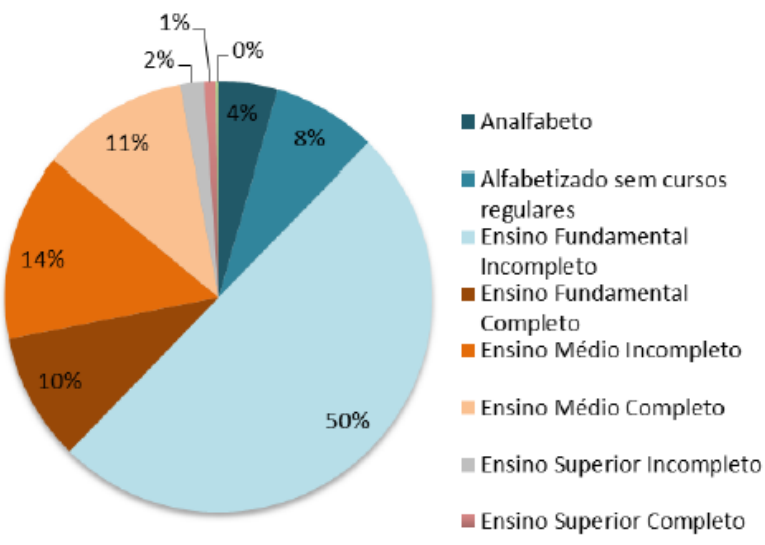

Gráfico 8 - Continente de proveniência das presas estrangeiras no Brasil

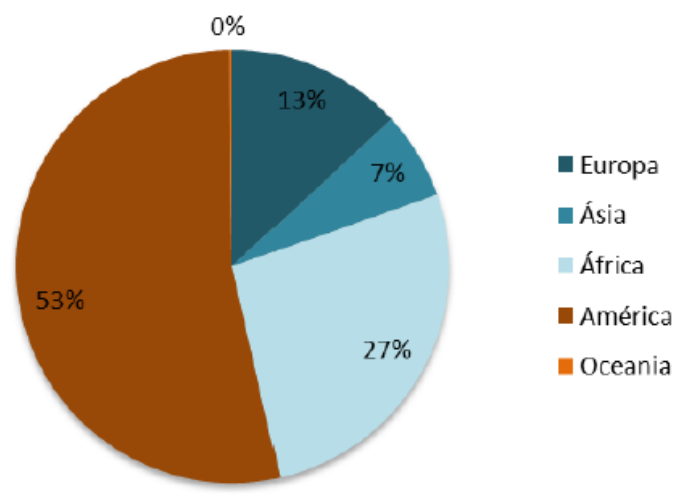


Gráfico 9 - Distribuição por gênero dos crimes tentados/consumados entre os registros das pessoas privadas de liberdade no Brasil
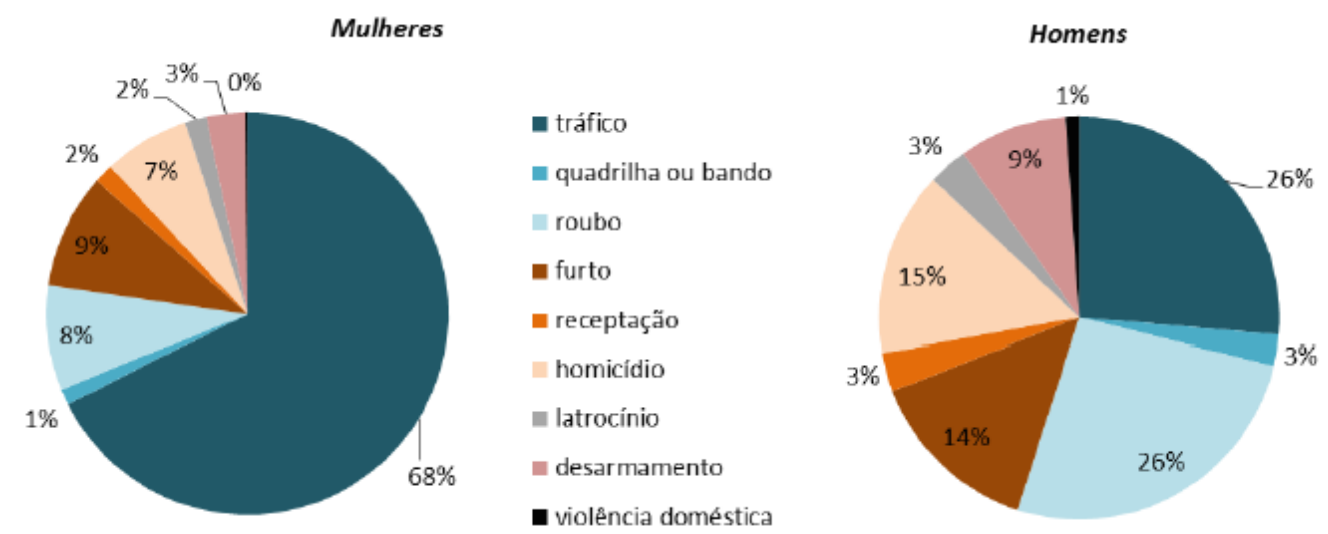

Gráfico 10 - Mulheres privadas de liberdade por natureza da prisão e tipo de regime no Brasil

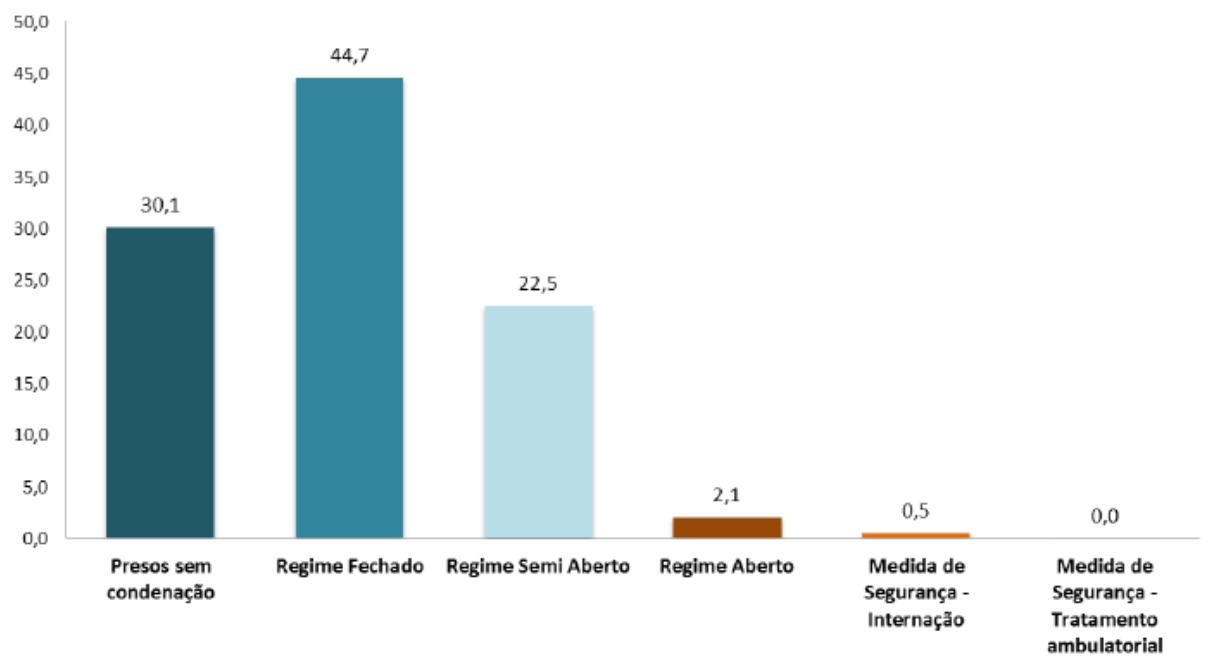


Gráfico 11 - Tempo total de penas da população prisional feminina condenada no Brasil

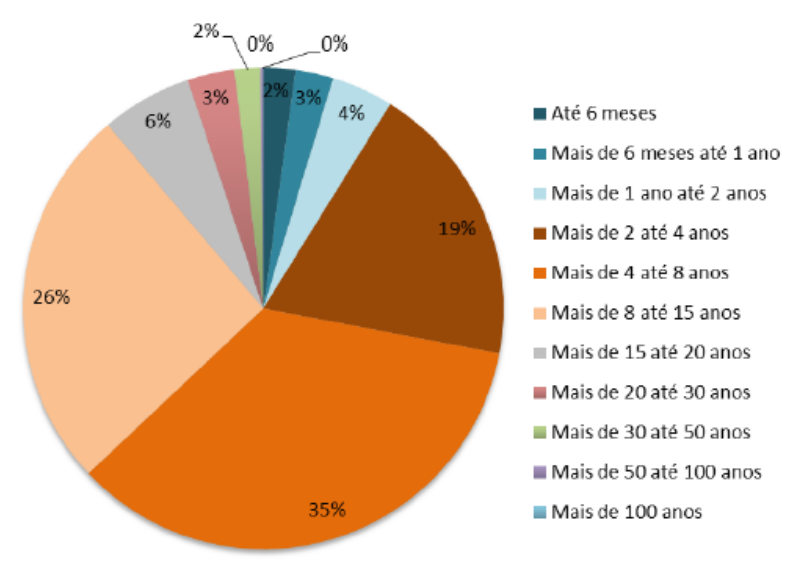

Todos os gráficos e estatísticas acima mencionados foram retirados do Levantamento Nacional de Informações Penitenciárias (InfoPen - Mulheres) de junho de 2014, último relatório existente no país perante a disponibilidade de informações com recorte de gênero sobre o tema.

Diante de tais amostras, o que se pode concluir é que o perfil da mulher encarcerada no Brasil é de uma pessoa:

- Jovem (50\% possuem menos de 30 anos e $68 \%$ menos de 35 anos);

- Negra (68\%) - o número de mulheres negras presas em comparação ao número de negros "livres" é proporcionalmente muito maior, pois estes representam 53\% da população brasileira geral;

- Solteira (57\%) - esta porcentagem é bastante relevante no que se refere a quantidade de mulheres chefes de família que existem no país e na responsabilidade para com os filhos (como é melhor abordado no capítulo 4);

- De baixa escolaridade (62\% não completaram sequer o ensino fundamental); 
- Cometeu crime de tráfico de drogas $(68 \%)$ - este número é muito importante, pois um dos motivos do aumento do encarceramento feminino tem conexão direta com o crime de tráfico de drogas e a Lei 11.343/2006 (como foi desenvolvido no Capítulo 1);

- Muitas delas fazem parte da abrangência relevante encontrada em situação de prisão sem condenação $(30,1 \%)$ - esta porcentagem significa que 11.269 mulheres se encontram, à época de junho de 2014, custodiadas no sistema prisional brasileiro e não possuem condenação definitiva. Ou seja, a cada 10 mulheres presas, 3 estão privadas de sua liberdade em situação provisória ou preventiva. O que é um número bem alto, tendo em vista que a liberdade é um princípio constitucional e o devido processo legal deveria ser respeitado antes de haver a respectiva privação (tema este que também pode ser conferido de forma mais profunda no Capítulo 4).

Conclui-se então que o perfil socioeconômico destas mulheres se encontra na base da pirâmide social. Nas próprias palavras do relatório InfoPen - Mulheres:

Esse conjunto de dados reflete dimensões bastante distintas, que permitem o cruzamento entre si e a elaboração de diagnósticos sobre as eventuais falhas do sistema de justiça criminal e também de políticas públicas, que também poderiam ser trazidas em maiores oportunidades sociais a perfis específicos de mulheres. ${ }^{45}$

45 Ibid., p. 20. Disponível em: <http://www.justica.gov.br/news/estudo-traca-perfil-da-populacaopenitenciaria-feminina-no-brasil/relatorio-infopen-mulheres.pdf> Acesso em: 03 de mai.2018. 


\section{Capítulo III - Os Direitos das Mulheres Encarceradas e suas Respectivas Violações}

Nos primórdios da civilização, para todo delito cometido, havia uma vingança em contrapartida. Este sistema emergia de um consenso social, o qual acreditava que através da punição se demonstraria aos demais indivíduos que o crime não compensaria, assim, reduzindo a sua incidência. Dessa forma, a crença era de que mediante a imposição de dor ao condenado, se garantiria, então, a harmonia e a paz daquela comunidade ${ }^{46}$.

Felizmente, não mais persistem as penais corporais, já que estas são tidas por incompatíveis com o sistema de justiça atual.

Nesse sentido, com o passar do tempo, houve uma evolução do pensamento crítico relacionado às sanções penais, acarretando em uma mudança positiva do tema.

A Carta Magna de 1988 trouxe, em seu artigo $1^{\circ}$, inciso III, o princípio da dignidade da pessoa humana, o qual constitui uma qualidade intrínseca a todo ser humano, lhe garantindo uma ampla gama de direitos e deveres fundamentais, o colocando a salvo de qualquer ato de cunho degradante ou desumano, bem como lhe assegurando o mínimo existencial necessário a uma vida saudável.

Dessa forma, o princípio da dignidade da pessoa humana - bastião de todo Estado Democrático de Direito - impede que o sofrimento físico ou mental seja elemento constitutivo da pena. O referido preceito está consubstanciado, também, em diversas outras normas do ordenamento, convindo destacar os incisos XLVII e XLIX do art. $5^{\circ}$ da CF.

Advento do pensamento liberal moderno, o cerne dos direitos humanos é a garantia dos direitos básicos dos cidadãos, pois funciona como ferramenta para proteger as pessoas. Para a surpresa de alguns, os presos são inclusos por este

\footnotetext{
${ }^{46}$ FOUCALT, Michel. Vigiar e Punir: Nascimento das prisões. 30ª ed. Petrópolis: Vozes, 2004. p. 15.
} 
rol. Assim, o Grupo de Estudos Carcerários Aplicados da Universidade de São Paulo afirma:

O preso adquiriu o status jurídico de sujeito de direitos. Trata-se de conquista histórica, obtida graças ao desenvolvimento do princípio da humanidade, que começou a firmar-se no primeiro quartel do século XX. A pessoa presa deixou de ser vista como objeto da execução penal ou do processo. A principal consequência dessa condição para o condenado e o para preso provisório foi a afirmação de suas respectivas humanidades, isto é, o reconhecimento de que são seres humanos, todavia, presos, um status que lhes é inalienável, por mais abjeto que seja o crime praticado pelo condenado, por mais repulsivo que seja o delito do qual o preso é acusado. A segunda consequência mais importante é a de que o preso passou a manter com o Poder Público que o custodia uma "relação jurídica de especial sujeição". Ou seja, o preso tem direitos perante a administração carcerária e deveres que deve observar, estando sujeito às determinações da administração penitenciária. ${ }^{47}$

Com base no referido princípio então, os direitos e garantias fundamentais aos cidadãos presos foram preconizados em diversos incisos do $\operatorname{artigo~} 5^{\circ}$ da Constituição Federal. Entretanto, ante a ponderação de seu parágrafo segundo, estes não ficam limitados apenas ao texto constitucional, podendo também serem verificados a partir de leis ordinárias ou tratados internacionais (inclusive, inúmeros diplomas normativos adotados pelo Brasil que abarcam a temática poderiam ser listados aqui, entretanto, não há o intuito de extensão demasiada, pois o objetivo é apenas proporcionar um panorama geral da situação da pessoa presa para mais tarde ser realizado um comparativo com a conjuntura da mulher encarcerada, portanto, apenas um será citado a título ilustrativo: a Lei de Execução Penais, a Lei 7.210/1984).

No que tange à LEP, por exemplo, esta possui papel fundamental nos deveres do Estado para com a pessoa presa. Para fins elucidativos, pode-se citar

\footnotetext{
${ }^{47}$ GECAp. A Constituição Federal, a Lei de Execução Penal e o preso - 7 informações básicas sobre encarceramento. São Paulo: Universidade de São Paulo, 2012. Disponível em: $<$ http://www.gecap.direitorp.usp.br/index.php/noticias/43-a-constituicao-federal-a-lei-de-execucaopenal-e-o-preso-7-informacoes-basicas-sobre-encarceramento> Acesso em: 18 de abr. 2018.
} 
os seis tipos de assistência determinados em seu artigo 11: material (fornecimento de alimentação, vestuário e instalações higiênicas), à saúde (atendimento médico, farmacêutico e odontológico), jurídica (fornecimento de advogado para aqueles que não possuem recursos financeiros para constituir um), educacional (acessibilidade à instrução escolar e profissional), social (amparo e preparo ao retorno do convívio em sociedade) e religiosa (atividades religiosas com infraestrutura para a prática de liberdade de culto). Além disso, existe uma série de direitos à integridade física e moral do preso listados no artigo 41.

Entretanto, nos cenários do cotidiano não há o devido respeito a estes direitos e garantias constitucionais. Na verdade, percebe-se uma dificuldade sem tamanho para a aplicação prática da letra da lei, como bem disserta Luis Greco:

\begin{abstract}
Indivíduos que foram condenados ao cumprimento de uma pena privativa de liberdade são afetos, diariamente, em sua dignidade, enfrentando problemas como superlotação carcerária, espancamentos, ausência de programas de reabilitação, falta de cuidados médicos, etc. A ressocialização do egresso é uma tarefa quase impossível, pois não existem programas governamentais para sua inserção social, além do fato de a sociedade, hipocritamente, não perdoar aquele que já foi condenado por ter praticado uma infração penal.

O princípio da dignidade da pessoa humana, ainda que relativizado, possui um núcleo essencial que deve ser preservado, impondo limites à própria atuação estatal e ao ius puniendi do Estado. E se é no Estado Democrático de Direito que o ius puniendi encontra seus fundamentos, também será nele que encontrará suas limitações. ${ }^{48}$
\end{abstract}

Não se pode negar, então, que a pena é um fato cultural enraizado em nossa sociedade. Muito embora a sua forma de imposição tenha se modificado com a evolução da sociedade, a essência da pena remanesce a mesma, estando ela incutida de caráter retributivo.

\footnotetext{
${ }^{48}$ GRECO, Luis. Modernização do direito penal, bens jurídicos coletivos e crimes de perigo abstrato. Rio de Janeiro: Lumen Juris, 2011. p. 98.
} 
Desta forma, é de extrema preocupação o panorama já vivenciado pela população prisional como um todo com relação ao descaso do Estado diante das necessidades básicas comuns destas pessoas. Acontece que do ponto de vista das mulheres encarceradas os obstáculos não param por aí: a supressão não se dá somente perante à violação de direitos humanos como também sob a condição de invisibilidade segundo a perspectiva da questão de gênero e seu respectivo tratamento especializado que lhes são de direito assegurado nacional e internacionalmente, conforme veremos a seguir.

\title{
3.1. A perpetuação do estigma da mulher dentro do cárcere
}

Como foi possível observar ao longo deste capítulo, a mulher possui um estigma e isso se desemboca no cárcere, assim como lá dentro se perpetua.

A prisão da mulher é uma quebra de expectativa da sociedade perante o exercício do papel feminino esperado. Esta passa ser vista como "transgressora" e a opressão estrutural do patriarcado e toda a violência já vivida em liberdade passa a se perpetuar em diversos aspectos nas próprias instituições prisionais. Larissa Urruth Pereira e Gustavo Noronha Ávila reforçam:

\begin{abstract}
Além do estigma normalmente atribuído àquele que delinque, a mulher desviante, em face da cultura patriarcal, carrega o rótulo de 'criminosa', bem como o de inconsequente e irresponsável (por agir sem pensar na criação dos filhos) e também acaba perdendo, perante os demais, a sua feminilidade, por praticar condutas socialmente atribuídas ao gênero masculino. Acaba que, mesmo delinquindo em menor expressão, a mulher tem sua punição majorada pelos préconceitos da sociedade. ${ }^{49}$
\end{abstract}

\footnotetext{
${ }^{49}$ PEREIRA, Larissa Urruth; ÁVILA, Gustavo Noronha de, Op. cit., p. 4/5. Disponível em:

<http://ebooks.pucrs.br/edipucrs/anais/cienciascriminais/IV/46.pdf> Acesso em: 03 de mai. 2018.
} 
Moral e socialmente condenada, sua pena se estende à mazelas do próprio sistema e inúmeros direitos da mulher presa são constantemente violados, já que aquele foi criado, desenvolvido e voltado para homens.

O Estado brasileiro, por sua vez, contraria todos os dias a própria normativa pátria ao exercer ou se omitir diante de atos violadores dos direitos das mulheres encarceradas, além, claro, da nítida infidelidade para com os compromissos por ele internacionalmente firmados, sejam estes tratados, recomendações ou convenções.

O ponto de partida aqui então será a realização de um levantamento das legislações que possuem recorte de gênero, mas são simplesmente ignoradas pela sociedade, administradores do direito, agentes penitenciários e pelo respectivo sistema e instituição prisional.

\subsubsection{Da violação aos direitos dos filhos das mulheres encarceradas}

Como já anteriormente abordado, a Constituição Federal tem o dever de estruturar juridicamente o Estado e é lá que podem ser encontradas os princípios, objetivos e políticas norteadores do Brasil. Desta forma, esta é considerada a lei de maior hierarquia dentro do nosso ordenamento, pois dispõe dos instrumentos para interpretar as demais normas jurídicas. Isso significa, portanto, que a Carta Magna contém elementos de praticamente todas as áreas do Direito e é de onde a legitimidade penal advém. Por isso, a grande importância do artigo $5^{\circ}$ para com as garantias e direitos das pessoas presas. E mais do que isso, enfim o reconhecimento da necessidade do desmembramento dos encarcerados por gênero e a inclusão dos direitos específicos das mulheres presas como é possível se ver em seu inciso $\mathrm{L}$ : 
Art. $5^{\circ}$. Todos são iguais perante a lei, sem distinção de qualquer natureza, garantindo-se aos brasileiros e aos estrangeiros residentes no País a inviolabilidade do direito à vida, à liberdade, à igualdade, à segurança e à propriedade, nos termos seguintes:

$[\ldots]$

$\mathrm{L}$ - às presidiárias serão asseguradas condições para que possam permanecer com seus filhos durante o período de amamentação.

Já não era sem tempo da conquista da igualdade material ser alcançada constitucionalmente assegurando mulheres de direitos específicos à pessoa que possui um útero e carrega outra vida dentro de si. Assim faz o inciso L e garante a estas que dão à luz a permanecerem com seu filho recém-nascido durante toda a fase de aleitamento materno ${ }^{50}$.

O objetivo desta norma é garantir o direito de amamentação da mãe, o dever de prover alimento da mãe para com seu filho e, por consequência, impedir que a criança sofra qualquer tipo de prejuízo. Isso porque tanto o leite materno quanto o ato de amamentar em si possuem uma série de benesses que a medicina e a psicologia explicam:

O leite materno constitui-se como alimento essencial para crescimento saudável do bebê, visto que o mesmo contém proteínas, anticorpos, gordura, vitaminas, ferro, açúcar, enzimas e fatores que propiciam o crescimento, aliado a resistência contra infecções e problemas cardiovasculares quando adulto; aumenta a capacidade cognitiva da criança, favorecendo o desenvolvimento intelectual. Infere-se que a literatura aponta para a existência do processo de amamentar como a melhor forma de contribuir para $o$ desenvolvimento da criança. ${ }^{51}$

Embora o leite materno apresente em sua composição aspectos nutritivos, denota-se que o processo de amamentar intensifica o vínculo afetivo entre mãe-bebê, pois o contato pele a pele imediatamente após o nascimento, aliado à amamentação, induz o

\footnotetext{
${ }^{50}$ As recomendações da Organização Mundial da Saúde (OMS) e do Ministério da Saúde é que a duração do aleitamento materno se perdure até a criança completar seis meses de idade. Depois disso, passa a ser alimento complementar até os dois anos de idade. Disponível em: <http://bvsms.saude.gov.br/bvs/ publicacoes/saude_crianca_nutricao_aleitamento_alimentacao.pdf > Acesso em: 05 de abr.2018.

${ }^{51}$ QUADROS, Pedro Oto; SANTA RITA, Rosangela Peixoto. Amamentação: direito da mãe ou da criança? Um olhar sobre as práticas do encarceramento feminino. Florianópolis: Tese para o Congresso da Associação Brasileira de Magistrados e Promotores de Justiça da Infância e da Juventude, 2008. p. 65.
} 
desenvolvimento do vínculo maternal, bem como amortiza o índice de rejeição e abandono dos conceptos. ${ }^{52}$

Além disso, importante mencionar que o inciso L está diretamente ligado ao inciso XLV e XLVI que preceituam os princípios constitucionais da intranscendência da pena e individualização da pena respectivamente. Isto é, nenhuma pessoa pode ser obrigada a cumprir pena por um ato praticado por outrem, como é o caso das crianças filhas de genitoras encarceradas, assim como, gestantes e lactantes devem receber tratamento específico para sua condição.

Desta forma, para o cumprimento eficaz da referida norma, é necessário que os institutos prisionais disponibilizem a infraestrutura condizente assim como a condição material a que se propõe.

Somente vinte e um anos após a garantia à amamentação das presas ser instituída pela Constituição Federal, há o acréscimo do tema pela Lei 11.942 à Lei de Execução Penal com a seguinte redação:

Art. 83. O estabelecimento penal, conforme a sua natureza, deverá contar em suas dependências com áreas e serviços destinados a dar assistência, educação trabalho, recreação e prática esportiva.

[...]

$\S 2^{\circ}$ Os estabelecimentos penais destinados a mulheres serão dotados de berçário, onde as condenadas possam cuidar de seus filhos, inclusive amamenta-los, no mínimo, até 6 (seis) meses de idade.

Art. 89. Além dos requisitos referidos no art. 88, a penitenciária de mulheres será dotada de seção para gestante e parturiente e de creche para abrigar crianças maiores de 6 (seis) meses e menores de 7 (sete) anos com a finalidade de assistir a criança desamparada cuja responsável estiver presa.

Ao passo que em 2016, a Lei 13.257 também trouxe alterações no Estatuto da Criança e do Adolescente no tocante à temática:

\footnotetext{
${ }^{52}$ REGO. José Dias. Aleitamento materno. $2^{\text {a }}$ edição. São Paulo: Atheneu, 2006, p. 99.
} 
Art. $9^{\circ}$. O poder público, as instituições e os empregadores propiciarão condições adequadas ao aleitamento materno, inclusive aos filhos de mães submetidas a medida privativa de liberdade.

$\S 1^{\circ}$ Os profissionais das unidades primárias de saúde desenvolverão ações sistemáticas, individuais ou coletivas, visando ao planejamento, à implementação e à avaliação de ações de promoção, proteção e apoio ao aleitamento materno e à alimentação complementar saudável, de forma contínua.

$\S 2^{\text {o. }}$ Os serviços de unidades de terapia intensiva neonatal deverão dispor de banco de leite humano ou unidade de coleta de leite humano.

É com grande pesar, entretanto, que afere-se que o texto da lei, seja este Constituição Federal, Lei de Execução Penal ou Estatuto da Criança e do Adolescente, não se concretiza na realidade da população prisional feminina, pois os estabelecimentos não oferecem condições adequadas para gestantes, lactantes ou seus respectivos recém-nascidos ${ }^{53}$. O ambiente é de superlotação e insalubridade, portanto, fadado ao descaso público ao não possuir infraestrutura e cuidado para a convivência de mães e seus filhos, como por exemplo: a ausência ou insuficiência de berçários e celas separadas. ${ }^{54}$

\subsubsection{Da violação ao direito de estabelecimento prisional próprio à mulher}

O atual Código Penal brasileiro é do ano de 1940 e foi disposto na época do Estado Novo pelo então presidente Getúlio Vargas. Desde seu advento, contou com duas únicas reformas apenas: a primeira em 1969 sob a égide do período antidemocrático e a outra em 1984, época esta de recente fim de regime ditatorial.

\footnotetext{
${ }^{53}$ Disponível em: <http://agenciabrasil.ebc.com.br/geral/noticia/2018-03/cnj-aponta-precariedade-empenitenciarias-que-abrigam-gestantes-e-lactantes $>$ Acesso em: 05 de abr.2018.

${ }^{54}$ BILIBIO, Gabrielli; BITENCOURT, Camila; BRUM, Eduarda; CORREA, Julia; FAVERO, Itauana; FLORES, Karine; LOPES, Vitória; OLIVEIRA, Aline; ROESLER, Gabriele; SILVA, Nicole; SOUTO, Raquel. Mulheres Encarceradas: A realidade das mulheres nos presídios brasileiros. Revista Interdisciplinar de Ensino, Pesquisa e Extensão, vol. 4, n. 01/2016. p. 397. Disponível em: $\langle$ http://revistaeletronica.unicruz.edu.br/index.php/eletronica/ article/view/4743> Acesso em: 28 de abr.2018.
} 
Estas informações históricas refletem bastante nas características de seu texto, assim como em sua estrutura conservadora, pois, segundo a professora universitária e pesquisadora da área, Maíra Cardoso Zapater, “[...] não é demais dizer que o Código Penal (e a legislação penal como um todo) é um retrato bastante fiel do desenho do poder político de um país". ${ }^{55}$

Conforme tema concernente ao Capítulo 1, o sistema carcerário brasileiro, assim como os Códigos, foi criado, desenvolvido e voltado para homens, pois mulheres apenas deveriam prestar obediência e transgredir normas não fazia parte do consenso ideológico do patriarcado. Logo, soluções paliativas tiveram que ser desenvolvidas em tudo que existia referente ao Direito Penal para que houvesse a inclusão de pessoas do gênero feminino.

Assim, no diploma legal em questão há apenas uma única menção com relação à questão de gênero no que se refere ao regime especial ao qual estas devem ser submetidas, redação esta que só surgiu diante da última reforma pela Lei 7.209/1984, como pode ser visto em seu artigo 37:

Art. 37. As mulheres cumprem pena em estabelecimento próprio, observando-se os deveres e direitos inerentes à sua condição pessoal, bem como, no que couber, o disposto neste Capítulo.

O termo "estabelecimento próprio" está diretamente ligado a especialidade da condição de mulher. Desta forma, os estabelecimentos prisionais para pessoas do gênero feminino não podem ser os mesmos dos que as do gênero masculino.

Mais tarde esta norma do Código Penal trouxe respaldo constitucional em seu artigo $5^{\circ}$, inciso XLVIII, o qual dita que:

\footnotetext{
${ }^{55}$ ZAPATER. Maíra Cardoso. O Código Penal de 1940: não parece que foi ontem? Coluna: A herança legal das ditaduras: nossas cicatrizes jurídicas. Revista Carta Capital. Brasil, 3 jun. 2016. Disponível em: <http://justificando.cartacapital.com.br/2016/06/03/o-codigo-penal-de-1940-nao-parece-que-foiontem/> Acesso em: 05 de abr.2018.
} 
Art. $5^{\circ}$. Todos são iguais perante a lei, sem distinção de qualquer natureza, garantindo-se aos brasileiros e aos estrangeiros residentes no País a inviolabilidade do direito à vida, à liberdade, à igualdade, à segurança e à propriedade, nos termos seguintes:

$[\ldots]$

XLVIII - a pena será cumprida em estabelecimento distintos, de acordo com a natureza do delito, a idade e o sexo do apenado.

E, por fim, veio a mudança perante a Lei de Execução Penal:

Art. 82. Os estabelecimentos penais destinam-se ao condenado, ao submetido à medida de segurança, ao preso provisório e ao egresso. $\S 1^{\circ}$. A mulher e o maior de 60 (sessenta) anos, separadamente, serão recolhidos a estabelecimento próprio e adequado à sua condição pessoal.

Como a maioria dos outros dispositivos já citados, que tiveram que se adaptar à situação especial da mulher, com este não é diferente. Apesar da LEP existir desde 1984, a norma que dita sobre estabelecimento próprio à pessoas do sexo feminino só apareceu em 1997 graças a Lei 9.460/1997 que alterou a redação do artigo 82, com a inclusão do referido parágrafo. Desta forma, trazendo oficialmente harmonia com o Código Penal que já havia sofrido alteração em 1984 (artigo 37) e também com a Constituição Federal que trouxe o tema como garantia em 1988 (artigo $5^{\circ}$, inciso XLVIII).

Importante lembrar, ainda, que o artigo 766 do Código de Processo Penal consta sobre a execução da internação como medida de segurança também abarca o assunto, trazendo a indicação no mesmo sentido:

Art. 766. A internação das mulheres será feita em estabelecimento próprio ou em seção especial.

Aqui faz-se um paralelo com o inciso XLVIII do artigo $5^{\circ}$ da Constituição Federal e artigo 37 do Código Penal. Tanto as penas quanto as medidas de segurança devem ser cumpridas em "estabelecimento próprio" para mulheres, 
tendo em vista sua condição específica de indivíduos do gênero feminino, além, é claro, do risco de violência sexual.

Entretanto, a realidade ainda vivida no Brasil é a existência de presídios e cadeias de natureza mista. ${ }^{56} \mathrm{Na}$ maioria das vezes, este espaço físico compartilhado é separado por muros improvisados ou simplesmente as mulheres se encontram em alas supostamente isoladas dos homens. ${ }^{57}$

Segundo dados do Levantamento Nacional de Informações Penitenciárias - InfoPen Mulheres, de junho de 2014, enquanto 75\% dos estabelecimentos prisionais são masculinos (1070 unidades no total), 17\% são mistos (239 unidades no total) e apenas $7 \%$ destes são destinados exclusivamente às mulheres (103 unidades no total $)^{58}$. E como se já não bastasse a existência inconstitucional de prédios mistos com alas, teoricamente, separadas, em diversas localidades do país, principalmente no que se refere a lugares pequenos e do interior, simplesmente não há nem essa divisória informal. Mulheres ficam expostas a ambientes com a presença de homens, estando assim ainda mais vulneráveis, como afirma Heidi Ann Cerneka com o seguinte exemplo:

É claro que existem localidades que nem essa adaptação há. Ademais, enfrentamos situações de tortura e ausência total desconsideração das necessidades femininas, como aquela de Abaetetuba, PA, onde uma jovem de quinze anos permaneceu por mais de vinte dias numa cela junto com trinta homens. Não podemos nem devemos nos iludir: a cela mista de Abaetetuba não é caso isolado. Há muitas outras "Abaetetubas" no país. ${ }^{59}$

\footnotetext{
56 Disponível em: 〈https://ponte.org/ser-mulher-em-um-sistema-prisional-feito-por-e-para-homens/> Acesso em: 01 de jun. 2018.

${ }^{57}$ CARVALHO. Maria Luciene Barbosa; FREITAS. Luana Duarte Assunção. As faces e os disfarces dos presídios femininos: violações $x$ direitos. XII Brasil: Seminário Nacional Demandas Sociais e Políticas Públicas na Sociedade Contemporânea. II Mostra Nacional de Trabalhos Científicos, edição 2016. p. 7. Disponível em: <http://online.unisc.br/acadnet/anais/index.php/snpp/article/view/ 14582/3270> Acesso em: 22 de abr.2018.

58 BRASIL. Dados Consolidados. Op. cit., p. 15. Disponível em: <http://www.justica.gov.br/ news/estudo-traca-perfil-da-populacao-penitenciaria-feminina-no-brasil/relatorio-infopen-mulheres. pdf> Acesso em: 04 de mai. 2018.

${ }^{59}$ CERNEKA. Heidi Ann. Homens que menstruam: considerações acerca do sistema prisional às especificidades da mulher, vol. 6, $\mathrm{n}^{\circ}$ 11, Belo Horizonte: Veredas do Direito, 2009. p. 66. Disponível em: <http://www.domhelder.edu.br/veredas_direito/pdf/60_77.pdf> Acesso em: 24 de abr. 2018.
} 


\subsubsection{Da violação ao direito de acompanhamento médico à mulher grávida}

Promulgada em 1984, a Lei 7.210 veio em época de restauração da democracia no país e é pioneira na América Latina ao dispor sobre o sistema de acompanhamento da execução das penas, da prisão cautelar e da medida de segurança. De cunho garantista, tal conjunto de normas segue as recomendações internacionais e seu conteúdo consagra vasto repertório de direitos (e não somente acerca das formalidades da dinâmica prisional, como era o esperado).

Logo em seu Capítulo II contempla-se o tema sobre a assistência que o Estado deve ter para com o condenado (seja ele preso ou internado) durante sua estadia no estabelecimento penal (seja prisão ou hospital de custódia). Com o objetivo de prevenir o crime e orientar o retorno à convivência em sociedade, estipulam-se seis tipos de assistências, conforme artigo 11: material, à saúde, jurídica, educacional, social e religiosa. Dos quinze artigos envolvidos, apenas dois envolvem um recorte específico para as mulheres.

O primeiro deles é o artigo $14, \S 3^{\circ}$ que trata sobre a assistência à saúde da mulher, cuja redação vem da seguinte maneira:

Art. 14. A assistência à saúde do preso e do internado, de caráter preventivo e curativo, compreenderá atendimento médico, farmacêutico e odontológico.

[...]

$\S^{\circ}$ Será assegurado acompanhamento médico à mulher, principalmente no pré-natal e no pós-parto, extensivo ao recémnascido.

Apesar da Lei de Execução Penal ser de 1984, o parágrafo em questão fora acrescentado apenas em 2009 pela Lei 11.942, cuja preocupação era de assegurar às mães presas e aos recém-nascidos condições mínimas de assistência. 
Inclusive, importante lembrar que tão somente sete anos depois do acréscimo do parágrafo terceiro ao artigo 14 da LEP, houve a respectiva (e tão esperada) inserção no Estatuto da Criança e do Adolescente em seu artigo $8^{\circ}$ diante do surgimento da Lei 13.257 em 2016, trazendo as políticas públicas para primeira infância. Isso pode ser considerado um grande descaso, pois o ECA existe desde 1990 e nunca antes fora cogitado sobre o acompanhamento médico à mulher gestante e seu filho. Isso significa, portanto, que a LEP estava muito mais avançada neste sentido.

Desta forma, com a respectiva alteração, o Estatuto da Criança e do Adolescente passou a prever o seguinte:

Art. $8^{\circ}$. É assegurado a todas as mulheres o acesso aos programas e às políticas de saúde da mulher e de planejamento reprodutivo e, às gestantes, nutrição adequada, atenção humanizada à gravidez, ao parto e ao puerpério e atendimento pré-natal, perinatal e pós-natal integral no âmbito do Sistema Único de Saúde.

$\S 1^{\circ} \mathrm{O}$ atendimento pré-natal será realizado por profissionais da atenção primária.

$\S 2^{\circ}$ Os profissionais de saúde de referência da gestante garantirão sua vinculação, no último trimestre da gestação, ao estabelecimento em que será realizado o parto, garantindo o direito de opção da mulher.

$\S 3^{\circ}$ Os serviços de saúde onde o parto for realizado assegurarão às mulheres e aos seus filhos recém-nascidos alta hospitalar responsável e contrarreferência na atenção primária, bem como acesso a outros serviços e a grupos de apoio à amamentação.

$\S 4^{\circ}$ Incumbe ao poder público proporcionar assistência psicológica à gestante e à mãe, no período pré e pós-natal, inclusive como forma de prevenir ou minorar as consequências do estado puerperal.

$\S 5^{\circ} \mathrm{A}$ assistência referida no $\S 4^{\circ}$ deste artigo deverá ser prestada também a gestantes e mães que manifestem interesse em entregar seus filhos para adoção, bem como a gestantes e mães que se encontrem em situação de privação de liberdade.

$\S 6^{\circ}$ A gestante e a parturiente têm direito a 1 (um) acompanhante de sua preferência durante o período do pré-natal, do trabalho de parto e do pós-parto imediato.

$\S 7^{\circ} \mathrm{A}$ gestante deverá receber orientação sobre aleitamento materno, alimentação complementar saudável e crescimento e desenvolvimento infantil, bem como sobre formas de favorecer a criação de vínculos afetivos e de estimular o desenvolvimento integral da criança. 
$\S 8^{\circ}$ A gestante tem direito a acompanhamento saudável durante toda a gestação e a parto natural cuidadoso, estabelecendo-se a aplicação de cesariana e outras intervenções cirúrgicas por motivos médicos. $\S 9^{\circ} \mathrm{A}$ atenção primária à saúde fará a busca ativa da gestante que não iniciar ou que abandonar as consultas de pré-natal, bem como da puérpera que não comparecer às consultas pós-parto.

$\S 10^{\circ}$ Incumbe ao poder público garantir à gestante e à mulher com filho na primeira infância que se encontrem sob custódia em unidade de privação de liberdade, ambiência que atenda às normas sanitárias e assistenciais do Sistema Único de Saúde para o acolhimento do filho, em articulação com o sistema de ensino competente, visando ao desenvolvimento integral da criança.

Como foi possível perceber, no referido dispositivo normativo são enumeradas garantias de proteção e atendimento específico à gestante, pois o seu amparo e bem-estar é, de modo reflexo, o amparo e bem-estar do feto que em seu útero se desenvolve. Este cuidado é importante, pois resguarda o direito à vida e também, por sua vez, concretiza o princípio da proteção integral da (futura) criança.

Especificamente deve haver a proteção especial da mulher no momento anterior ao parto, durante a gestação e também no acompanhamento no momento posterior ao nascimento da criança ${ }^{60}$. Ou seja, é necessário que o poder público disponibilize serviços médicos à gestante através do Sistema Único de Saúde, além, obviamente, dos cuidados com o próprio recém-nascido.

Desde o ano de 2009, com as alterações/acréscimos da Lei de Execução Penal, para cá, em 2016, com o advento da Lei 13.257, nada mudou ${ }^{61}$. As garantias continuam a se ater ao papel e a realidade prisional brasileira é bem triste e fria, a qual mulheres encarceradas em situação de gravidez ou em estado

\footnotetext{
${ }^{60}$ ALENCASTRO, Paola Larroque. Mães presidiárias e o direito da criança e do adolescente à convivência familiar. Trabalho de Conclusão de Curso (Graduação). Rio Grande do Sul: Pontifícia Universidade do Rio Grande do Sul. Rio Grande do Sul, p. 21 Disponível em: $<$ http://www3.pucrs.br/pucrs/files/uni/poa/direito/graduacao/tcc/tcc2/trabalhos2015_1/paola_alencastr o.pdf> Acesso em: 01 de jun. 2018.

${ }_{61}$ Disponível em: <https://ponte.org/mesmo-com-mudancas-na-lei-brasil-nao-garante-direitos-dasgravidas-presas/> Acesso em: 01 de jun. 2018.
} 
de puerpério, assim como seus bebês, carecem de acompanhamento médico adequado, conforme corrobora o seguinte relato:

Um dos problemas que norteiam as mulheres encarceradas é a questão atinente à gravidez. $\mathrm{O}$ tratamento para com as gestantes do sistema prisional é alarmante, uma vez que elas não recebem o devido acompanhamento médico pré-natal e nem mesmo na hora do parto. [...] o momento do parto é indiferente para muitos dos agentes penitenciários, visto que eles ignoram o sofrimento das mesmas e há casos de partos que são feitos dentro dos presídios, tendo como alegação a falta de viaturas para levá-las até o hospital. ${ }^{62}$

Um exemplo da vida real a ser citado é a situação das grávidas do Presídio Talavera Bruce. O estudo de caso "Mulheres e crianças encarceradas: um estudo jurídico-social sobre a experiência da maternidade no sistema prisional do Rio de Janeiro" demonstrou que as presas não realizaram o pré-natal de forma completa, havendo tido somente a coleta de sangue e urina e o exame de ultrassonografia. Todos os outros procedimentos mais profundos foram simplesmente esquecidos/ignorados pela instituição prisional em questão. ${ }^{63}$

\subsubsection{Da violação ao direito de permanência de agentes penitenciários exclusivamente do sexo feminino}

Os próximos artigos com recorte de gênero a serem analisados são o 77, $\S 2^{\circ}$ e o $83, \S^{\circ}$ da Lei de Execução Penal, ambos com conteúdo em comum:

\footnotetext{
${ }^{62}$ BILIBIO, Gabrielli; BITENCOURT, Camila; BRUM, Eduarda; CORREA, Julia; FAVERO, Itauana; FLORES, Karine; LOPES, Vitória; OLIVEIRA, Aline; ROESLER, Gabriele; SILVA, Nicole; SOUTO, Raquel. Op. cit., p. 397/398. Disponível em: <http://revistaeletronica.unicruz.edu.br/ index.php/ eletronica/article/view/4743> Acesso em: 28 de abr.2018.

63 BOITEUX, Luciana, FERNANDES, Maíra, PANCIERI, Aline e CHERNICHARO, Luciana. Mulheres e crianças encarceradas: um estudo jurídico-social sobre a experiência da maternidade no sistema prisional do Rio de Janeiro. p. 2/3. Disponível em: <https://www.academia.edu /19036368/Mulheres_e_Crianças_Encarceradas_um_estudo_jur\%C3\%ADdico-social_sobre_a_ experiência_da_maternidade_no_sistema_prisional_do_Rio_de_Janeiro> Acesso em: 14 de mar.2018.
} 
Art. 77. A escolha do pessoal administrativo, especializado, de instrução técnica e de vigilância atenderá a vocação, preparação profissional e antecedentes pessoais do candidato.

[..]

$\S 2^{\circ}$ No estabelecimento para mulheres somente se permitirá o trabalho de pessoal do sexo feminino, salvo quando se tratar de pessoal técnico especializado.

Art. 83. O estabelecimento penal, conforme a sua natureza, deverá contar em suas dependências com áreas e serviços destinados a dar assistência, educação trabalho, recreação e prática esportiva.

[...]

$\S 2^{\circ}$ Os estabelecimentos penais destinados a mulheres serão dotados de berçário, onde as condenadas possam cuidar de seus filhos, inclusive amamenta-los, no mínimo, até 6 (seis) meses de idade.

$\S 3^{\circ}$ Os estabelecimentos de que trata o $\$ 2^{\circ}$ deste artigo deverão possuir, exclusivamente, agentes do sexo feminino na segurança de suas dependências internas.

Como pode ser visto, a mesma imposição legal ocorre duas vezes no mesmo diploma (o primeiro do texto original da LEP em 1984 e o segundo reforçado pela alteração da Lei 12.121/2009). Isso significa que tanto os agentes penitenciários quanto a direção dos estabelecimentos prisionais femininos devem ser compostos por equipes de mulheres. As exceções são apenas ao pessoal técnico especializado que adentra o local a fim de cumprir qualquer tipo de diligência em si.

Acredita-se que a justificativa se dá diante de inúmeras circunstâncias: 1 - agentes penitenciários do sexo feminino podem compreender melhor as necessidades das encarceradas por também serem mulheres; 2 - o evidente constrangimento que mulheres devem sentir ao conviver e compartilhar momentos do dia a dia, muitas vezes íntimos, como tomar banho, ir ao banheiro ou trocar de roupa, perante agentes penitenciários do sexo oposto; 3 - maus tratos e abuso sexual por parte de agentes penitenciários masculinos. ${ }^{64}$

64 Disponível em: <https://www.conjur.com.br/2010-jan-04/presidios-mulheres-terao-substituiragentes-sexo-masculino> Acesso em: 01 de jun. 2018. 
Acontece que esta exigência não faz qualquer sentido se a maioria das mulheres se encontra localizada em presídios masculinos e/ou mistos ${ }^{65}$. Além disso, mesmo nos estabelecimentos prisionais restritivos para mulheres, a realidade é que a grande parte dos agentes ainda é do sexo masculino ${ }^{66}$ e esse tipo de violência velada ainda é um problema no Brasil.

\subsubsection{Da violação ao direito à prisão domiciliar das mulheres abarcadas pelas hipóteses legais}

Outro tema com recorte de gênero a ser mencionado é a prisão domiciliar. Tanto a Lei de Execução Penal quanto o Código de Processo Penal preconizam hipóteses que garantem às mulheres que preencherem os pressupostos legais esta possibilidade, são estes:

Art. 117. Somente se admitirá o recolhimento do beneficiário de regime aberto em residência particular quando se tratar de:

[...]

III - condenada com filho menor ou deficiente físico ou mental;

IV - condenada gestante.

Art. 318. Poderá o juiz substituir a prisão preventiva pela domiciliar quando o agente for:

[...]

IV - gestante;

V - mulher com filho de até 12 (doze) anos de idade incompletos;

Assim como preconiza o artigo 318 do Código de Processo Penal, o artigo 117 da Lei de Execução Penal possui a mesma função, entretanto, se diferenciam apenas no que se refere ao status da pessoa: no primeiro a substituição é em decorrência da prisão preventiva e no segundo é cabível perante a pena de prisão

65 BRASIL. Dados Consolidados. Op. cit., p. 15. Disponível em: <http://www.justica.gov.br Inews/estudo-traca-perfil-da-populacao-penitenciaria-feminina-no-brasil/relatorio-infopen-mulheres. pdf> Acesso em: 04 de mai.2018.

${ }_{66}$ Ibid., p. 75. Disponível em: <http://www.justica.gov.br/news/mj-divulgara-novo-relatorio-doinfopen-nesta-terca-feira/relatorio-depen-versao-web.pdf > Acesso em: 01 de jun.2018. 
definitiva, ou seja, já houve condenação e esta tem a possibilidade de cumpri-la em regime aberto.

De bastante abrangência e importância, a prisão domiciliar possui um capítulo do respectivo trabalho inteiramente dedicado a este ponto. Assim, aqui será apenas mais um local de apontamento sobre a existência da norma do que realmente desenvolver qualquer coisa. Logo, para maiores informações, consultar Capítulo 4.

Resumidamente, a crítica em questão se dá pela dificuldade pelo Poder Judiciário de aplicar a letra da lei às estas mulheres, que continuam desnecessariamente dentro dos estabelecimentos penais.

\subsubsection{Da violação à vedação que a lei prevê ao uso de algemas em mulheres parturientes}

Datado praticamente à mesma época do nosso último Código Penal, o atual Código de Processo Penal também foi legado do então presidente Getúlio Vargas durante o período do Estado Novo. Assim, é de se reconhecer incompatibilidade entre alguns de seus dispositivos normativos e a Constituição Federal de 1988. Ainda que alterações legislativas tenham sido realizadas em 2008, é possível considerar o Código em si como antiquado, principalmente no concernente às mulheres.

No que se refere ao recorte de gênero, objeto de estudo em questão tratado no presente capítulo, o Código de Processo Penal, tem-se o parágrafo único do artigo 292:

Art. 292. Se houver, ainda que por parte de terceiros, resistência à prisão em flagrante ou à determinada por autoridade competente, o executor e as pessoas que o auxiliarem poderão usar dos meios necessários para defender-se ou para vencer a resistência, do que tudo se lavrará auto subscrito também por duas testemunhas. 
Parágrafo Único. É vedado o uso de algemas em mulheres grávidas durante os atos médico-hospitalares preparatórios para a realização do parto e durante o trabalho de parto, bem como em mulheres durante o período de puerpério imediato.

A explicação se dá perante a lógica do artigo 284 do Código de Processo Penal, no qual veda-se o emprego de força das autoridades competentes contra o preso. As ressalvas trazidas logo em seguida, em caso de resistência ou tentativa de fuga do preso, deu ensejo à discussão acerca do uso de algemas durante este emprego da força. Assim, surgiu então a Súmula Vinculante $\mathrm{n}^{\circ} 11$ para esclarecer de vez, sendo reforçado pelo artigo $2^{\circ}$ do Decreto 8.858/2016, permitindo o uso das algemas no preso quando as exceções do referido artigo 284 ocorrerem.

A condição da mulher gestante, obviamente, não a inclui em qualquer tipo de rol para uso de algema. Assim, com a entrada em vigor da Lei 13.434/2017, recentemente fora incorporado ao Código de Processo Penal a vedação ao uso de algemas por mulheres grávidas em condições de pré, durante e pós-parto. Entretanto, não deveria ser novidade no sistema jurídico brasileiro atual, uma vez que este conteúdo já era previsto desde 2016 no artigo $3^{\circ}$ do Decreto 8.858/2016:

Art. $3^{\circ}$. É vedado emprego de algemas em mulheres presas em qualquer unidade do sistema penitenciário nacional durante $\mathrm{o}$ trabalho de parto, no trajeto da parturiente entre a unidade prisional e a unidade hospitalar e após o parto, durante o período em que se encontrar hospitalizada.

Inclusive ambas as normas citadas possuem concordância com a Regra 24 da Resolução 61/143 de 2006, mais conhecido como Regras de Bangkok, compromisso internacional este que o Brasil assumiu com a Organização das Nações Unidas para o tratamento de mulheres presas: 
Regra 24. Instrumentos de contenção jamais deverão ser usados em mulheres em trabalho de parto, durante o parto e nem no período imediatamente posterior.

A realidade, infelizmente, não condiz com as garantias proporcionadas pela teoria: um exemplo interessante a ser citado é a pesquisa "Mulheres e crianças encarceradas: um estudo jurídico-social sobre a experiência da maternidade no sistema prisional do Rio de Janeiro. Este revela diversas denúncias acerca do tratamento recebimento pelas mulheres presas em situação de gravidez, dentre elas, o uso indevido das algemas durante o parto. ${ }^{67}$

A crítica acerca da atitude de algemar parturientes é contundente:

A maneira como muitas gestantes são tratadas gera revolta, uma vez que as mesmas sentindo fortes contrações se encontram com os pés e/ou mãos algemados na cabeceira ou ao pé da cama. Atitude humanamente lastimável, pois além de já estarem sentindo dores, as algemas podem machucar ainda mais. A ativista Heidi Cerneka ${ }^{68}$ faz seu comentário a respeito desse tratamento no livro 'Presos que Menstruam' ${ }^{69}$ onde relata: 'Tem mulher que até dá à luz algemada na cama. Como se ela pudesse levantar parindo e sair correndo. [...]. Porque mesmo que ela pudesse levantar, qualquer policial com uma perna só andaria mais rápido que ela'. ${ }^{70}$

${ }^{67}$ BOITEUX, Luciana, FERNANDES, Maíra, PANCIERI, Aline e CHERNICHARO, Luciana. Op. cit., p. 3. Disponível em: <https://www.academia.edu/19036368/Mulheres_e_Crianças_Encarceradas _um_estudo_jur\% $\%$ \% ADdicosocial_sobre_a_experiência_da_maternidade_no_sistema_prisional_do Rio de Janeiro> Acesso em: 14 de mar. 2018.

68 "Ativista americana que trabalha há 13 anos, com a causa da mulher presa, no Brasil na Pastoral Carcerária." BILIBIO, Gabrielli; BITENCOURT, Camila; BRUM, Eduarda; CORREA, Julia; FAVERO, Itauana; FLORES, Karine; LOPES, Vitória; OLIVEIRA, Aline; ROESLER, Gabriele; SILVA, Nicole; SOUTO, Raquel. Op. cit., p. 397. Disponível em: <http://revistaeletronica.unicruz.edu. br/index.php/eletronica/ article/view/4743> Acesso em: 28 de abr. 2018.

69 "Livro da escritora Nana Queiroz que fala sobre o cotidiano das prisões femininas no Brasil, onde dá voz às presas (e às famílias delas), desde os episódios que as levaram à cadeia até o cotidiano no cárcere". Ibid, p. 397. apud QUEIROZ, Nana. Presos que menstruam: A brutal vida das mulheres - tratadas como homens - nas prisões brasileiras. Rio de Janeiro: Record, 2015, p. 21/22.

${ }^{70}$ BILIBIO, Gabrielli; BITENCOURT, Camila; BRUM, Eduarda; CORREA, Julia; FAVERO, Itauana; FLORES, Karine; LOPES, Vitória; OLIVEIRA, Aline; ROESLER, Gabriele; SILVA, Nicole; SOUTO, Raquel. Op. cit., p. 398. Disponível em: 〈http://revistaeletronica.unicruz.edu.br/index.php/eletronica/ article/view/4743> Acesso em: 28 de abr. 2018. 


\subsubsection{Da violação ao direito ao ensino profissional completo da mulher}

O próximo artigo a ser aqui mencionado é o parágrafo único do artigo 19 da Lei de Execução Penal sobre o âmbito da assistência educacional da mulher que dispõe o seguinte:

Art. 19. O ensino profissional será ministrado em nível de iniciação ou de aperfeiçoamento técnico.

Parágrafo único. A mulher condenada terá ensino profissional adequado à sua condição.

A assistência educacional que o Estado deve prover aos presos é a acessibilidade à instrução escolar e profissional. No caso do artigo supramencionado refere-se ao ensino profissional e o nível de iniciação ou de aperfeiçoamento técnico a que deva ser ministrado.

Seu parágrafo único, entretanto, faz uma ressalva com relação ao ensino profissional da mulher. A norma em questão não adveio de acréscimos ou mudanças posteriores, é do texto original de 1984 da LEP. Ou seja, é passível de se ter receio com relação a algum tipo de objetivo obscuro por trás, pois ao conhecimento não há qualquer tipo de necessidade de tratamento diferenciado entre homens e mulheres. Ambos são plenamente capazes de desenvolverem habilidades em qualquer área de sua escolha. Assim, acredita-se que a real função aqui seria a divisão de gênero para a especialização forçada das mulheres em trabalhos domésticos ao invés de prepará-las para o mercado de trabalho. ${ }^{71}$

Aliás, a questão da educação diferenciada corrobora diretamente com o entendimento de Larissa Urruth Pereira e Gustavo Noronha Ávila acerca do trabalho dentro da prisão a elas ofertado:

\footnotetext{
${ }^{71}$ FÉLIX, Ynes da Silva. Mulher, estranha e condenada: sobre as imigrantes que cumprem pena privativa de liberdade no Brasil. Curitiba: Revista Jurídica vol. 4, no 49, 2017. p. 298. Disponível em: 〈http://revista.unicuritiba.edu.br/index.php/RevJur/article/viewFile/2295/1425> Acesso em: 02 de jul. 2018.
} 
Em relação às atividades laborais ofertadas, o que se vislumbra massivamente são os serviços de tapeçaria, lavagem de roupa e artesanato, reforçando o papel submisso da mulher na sociedade e, ao contrário do que se espera, não dando a essas mulheres condições de manter-se, durante a vida extramuros, de forma independente através dos trabalhos ensinados no cárcere, impondo-as a uma condição de dependência e incapacidade de tomar decisões. ${ }^{72}$

\subsubsection{Das violações gerais a recomendações, tratados ou convenções de âmbito internacional}

A partir da decisão do Presidente da República em tornar o Brasil signatário de determinado compromisso internacional, este adquire responsabilidade global para com os outros estados-nação. Desrespeitar qualquer tipo de recomendação, tratado ou convenção é violar normas imperativas de Direito Internacional e, teoricamente, aplicar sansão ao infrator é a consequência legal da feitura de ato ilícito. Por tabela, há a quebra de confiança para com à comunidade exterior.

Exemplos pertinentes ao nosso objeto de estudo são: a Convenção Interamericana para Prevenir, Punir e Erradicar a Violência contra a Mulher (a chamada de "Convenção de Belém do Pará") 73 e, também, as Regras das Nações Unidas para o Tratamento de Mulheres Presas e Medidas Não Privativas de Liberdade para Mulheres Infratoras (conhecida como "Regras de Bangkok"). ${ }^{74}$

A Convenção de Belém do Pará, adotada em 1994 pela Organização do Estados Americanos (OEA), é compreendida como marco histórico

\footnotetext{
72 PEREIRA, Larissa Urruth; ÁVILA, Gustavo Noronha de. Op. cit., p. 6. Disponível em: 〈http://ebooks.pucrs.br/edipucrs/anais/cienciascriminais/IV/46.pdf $>$ Acesso em: 05 de abr. 2018.

${ }^{73} \mathrm{CIDH}$. Convenção Interamericana para Prevenir, Punir e Erradicar a Violência contra a Mulher (“Convenção Belém-do-Pará”). Belém-do-Pará, 1994. Disponível em: 〈http://www.cidh.org/Basicos/Portugues/m.Belem.do.Para.htm> Acesso em: 02 de jun.2018.

${ }^{74}$ ONU. Regras das Nações Unidas para o Tratamento de Mulheres Presas e Medidas Não Privativas de Liberdade para Mulheres Infratoras ("Regras de Bangkok"). Tradução (Brasília, 2016): Conselho Nacional de Justiça e Departamento de Monitoramento e Fiscalização do Sistema Carcerário e do Sistema de Execução de Medidas Socioeducativas. Bangkok, 2010. Disponível em: 〈http://www.cnj.jus.br/files/conteudo/arquivo/2016/03/a858777191da58180724ad5caafa6086.pdf〉 Acesso em: 02 de jun.2018.
} 
internacional para imposição de limites no que se refere à violência contra mulheres. ${ }^{75}$

O Brasil ao ratificá-la em 1995 passou a se obrigar perante a incorporação de normas na lei brasileira que visassem a solução deste problema. Inclusive no que se refere a especial atenção à vulnerabilidade das mulheres encarceradas, como reconhece seu artigo 9, no capítulo dos deveres dos estados:

Art. 9. Para a adoção das medidas a que se refere este capítulo, os Estados Partes levarão especialmente em conta a situação da mulher vulnerável a violência por sua raça, origem étnica ou condição de migrante, de refugiada ou de deslocada, entre outros motivos. Também será considerada sujeitada a violência a gestante, deficiente, menor, idosa ou em situação sócio-econômica desfavorável, afetada por situações de conflito armado ou de privação de liberdade.

Isto significa que tudo aquilo estipulado no capítulo em questão (artigos 7 e 8) para adoção das políticas destinadas a prevenir, punir e erradicar a violência contra a mulher incluem as que se encontram em situação de prisão, pois estas deveriam estar somente privadas de sua liberdade, e não de todos os outros direitos.

Diferentemente da Convenção de Belém do Pará que possui um propósito mais abrangente com relação as mulheres em geral, e que incluem em categoria especial aquelas encarceradas tendo em vista sua clara situação de vulnerabilidade, as Regras de Bangkok têm o objetivo de albergar especificamente as necessidades das mulheres em situação de privação de liberdade.

A imprescindibilidade de tratar da questão dos direitos das presidiárias, e consequentemente de seus filhos, gerou a aprovação pela Assembleia Geral da Organização das Nações Unidas (ONU) em 2010.

\footnotetext{
${ }^{75}$ OLIVEIRA, Anna Caroline Lopes de Oliveira. A Influência da Convenção de Belém do Pará na Prevenção da Violência contra as Mulheres no Brasil, Chile e Guatemala. Trabalho de Conclusão de Curso (Graduação). Brasília: Centro Universitário de Brasília, Brasília, 2017. p. 30. Disponível em: $<$ http://repositorio.uniceub.br/bitstream/235/11151/1/21391717.pdf > Acesso em: 02 de jun.2018.
} 
As tentativas de resolução das dificuldades de gênero no sistema carcerário são enumeradas em setenta regras no total e o escopo do texto é dividido em quatro seções: regras de aplicação geral, regras aplicáveis a categorias especiais, medidas não restritivas de liberdade, pesquisa, planejamento, avaliação e sensibilização pública. O princípio básico aqui a ser considerado é a igualdade material e, assim, tratam sobre importantes questões concernentes à mulher, tais quais: ingresso; registro; alocação; higiene pessoal; serviços de cuidado à saúde (atendimento médico específico para mulheres, cuidados com a saúde mental, entre outros); segurança e vigilância (revistas, disciplinas e sanções, instrumentos de contenção, vistorias); contato com o mundo exterior (troca de cartas, visitas de familiares e amigos, visitas íntimas); funcionários penitenciários e sua capacitação; unidades de internação para adolescentes do sexo feminino em conflito com a lei; cuidados específicos para com presas condenadas que se encaixem na categoria de mulheres gestantes, com filhos e lactantes na prisão, estrangeiras, minorias e povo indígenas ou presas cautelarmente ou esperando julgamento.

Vale lembrar que o Brasil constitui estado-membro da ONU e tem o dever de respeito às regras. Acontece que nesses seis anos de existência do documento internacional, a aplicação e cumprimento das regras simplesmente não ocorreu, tendo em vista que somente em 2016 houve a tradução oficial do documento para o português pelo Conselho Nacional de Justiça $(\mathrm{CNJ})^{76}$. Assim, pode-se dizer que apenas recentemente ocorreu a devida incorporação às diretrizes das Regras de Bangkok em suas normas internas, trazendo assim importantes inovações no que consta aos direitos e garantias das mulheres encarceradas. Infelizmente, os presídios falam por sí só e demonstram o quanto a prática ainda deixa a desejar da teoria.

\footnotetext{
76 Disponível em: <https://nacoesunidas.org/conselho-nacional-de-justica-publica-versao-emportugues-de-regras-da-onu-sobre-detencao-de-mulheres/> Acesso em: 06 de abr. 2018.
} 


\subsection{O desenlace entre efetividade e invisibilidade}

Diante de todo o exposto ao longo do presente tópico, conclui-se que o tema das mulheres encarceradas foi abraçado pela esfera internacional, conferindo direitos e garantias a este grupo considerado como vulnerável. Mais tarde, fora incorporado também pela legislação brasileira. Contudo, o "papel" destoa da realidade vivida nas prisões, pois as leis existem, mas simplesmente não são aplicadas. As necessidades das presas não vêm sendo tratadas como assunto de prioridade e há, não só a nítida violação de direitos destas mulheres, como também no âmbito dos direitos humanos. Assim, veste-se o véu da invisibilidade diante da ausência de investimento efetivo do Estado em políticas públicas com relação à questão de gênero em ambiente prisional.

Inclusive, para melhor visualização e dinâmica dos tópicos abordados ao longo deste capítulo, a Tabela 4, de elaboração própria, é exposta logo em subsequência, fornecendo um panorama geral dos direitos das mulheres encarceradas e suas respectivas previsões legais.

Por fim, vale dizer que a ideia de unir teoria (legislações existentes) e prática (realidade vivida), apontando assim as violações respectivas, foi inspirado pela leitura dos relatos das próprias mulheres encarceradas nos livros "Presos que menstruam", publicação de Nana Queiroz, e "Cadeia: relatos sobre mulheres", de Debora Diniz. Ambas as pesquisadoras adentram o universo das prisões femininas e utilizam a perspectiva dos sujeitos em primeira pessoa como forma de denúncia. 
Tabela 4 - Direitos das mulheres encarceradas e respectivas previsões legais

\begin{tabular}{|c|c|c|c|c|c|c|c|c|c|c|c|c|c|c|}
\hline & \multicolumn{2}{|c|}{$\begin{array}{l}\text { Direitos dos filhos } \\
\text { das mulheres } \\
\text { encarceradas }\end{array}$} & \multicolumn{2}{|c|}{$\begin{array}{c}\text { Direito de } \\
\text { estabelecimento } \\
\text { prisional próprio à } \\
\text { mulher }\end{array}$} & \multicolumn{2}{|c|}{$\begin{array}{c}\text { Direito de } \\
\text { acompanhamento } \\
\text { médico à mulher } \\
\text { grávida }\end{array}$} & \multicolumn{2}{|c|}{$\begin{array}{c}\text { Direito de } \\
\text { permanência de } \\
\text { agentes } \\
\text { penitenciários } \\
\text { exclusivamente do } \\
\text { sexo feminino }\end{array}$} & \multicolumn{2}{|c|}{$\begin{array}{c}\text { Direito à prisão } \\
\text { domiciliar das } \\
\text { mulheres abarcadas } \\
\text { pelas hipóteses } \\
\text { legais }\end{array}$} & \multicolumn{2}{|c|}{$\begin{array}{c}\text { Direito à vedação ao } \\
\text { uso de algemas em } \\
\text { mulheres } \\
\text { parturientes }\end{array}$} & \multicolumn{2}{|c|}{$\begin{array}{l}\text { Direito ao ensino } \\
\text { profissional } \\
\text { completo da mulher }\end{array}$} \\
\hline & $\begin{array}{c}\text { Dispositivo } \\
\text { legal }\end{array}$ & Advento & $\begin{array}{c}\text { Dispositivo } \\
\text { legal }\end{array}$ & Advento & $\begin{array}{c}\text { Dispositivo } \\
\text { legal }\end{array}$ & Advento & $\begin{array}{c}\text { Dispositivo } \\
\text { legal }\end{array}$ & Advento & $\begin{array}{c}\text { Dispositivo } \\
\text { legal }\end{array}$ & Advento & $\begin{array}{c}\text { Dispositivo } \\
\text { legal }\end{array}$ & Advento & $\begin{array}{c}\text { Dispositivo } \\
\text { legal }\end{array}$ & Advento \\
\hline CF & $\underset{\mathrm{L}}{\text { Artigo }} 5^{\circ}$ & $\begin{array}{c}\text { CF/ } \\
1988 \\
\end{array}$ & $\begin{array}{c}\text { Artigo } 5^{\circ}, \\
\text { XLVIII }\end{array}$ & $\begin{array}{c}\text { CF/ } \\
1988 \\
\end{array}$ & --- & --- & --- & --- & --- & --- & --- & --- & --- & --- \\
\hline LEP & $\begin{array}{c}\text { Artigos } 83 \\
\$ 2^{\circ} \text { e } 89\end{array}$ & $\begin{array}{l}\text { Lei } \\
11.942 / \\
2009\end{array}$ & $\begin{array}{l}\text { Artigo } 82 \\
\$ 1^{\circ}\end{array}$ & $\begin{array}{l}\text { Lei } \\
9.460 / \\
1997\end{array}$ & $\begin{array}{c}\text { Artigo 14, } \\
\S 3^{\circ}\end{array}$ & $\begin{array}{l}\text { Lei } \\
11.942 / \\
2009\end{array}$ & $\begin{array}{l}\text { Artigos } 77 \\
\$ 2^{\circ} \text { e } 83 \\
\S 3^{\circ}\end{array}$ & $\begin{array}{c}\text { LEP/ } \\
1984 \text { e } \\
\text { Lei } \\
12.121 / \\
2009\end{array}$ & $\begin{array}{c}\text { Artigo } 117 \\
\text { III e IV }\end{array}$ & $\begin{array}{l}\text { LEP/ } \\
1984\end{array}$ & --- & --- & $\begin{array}{c}\text { Artigo 19, } \\
\text { PU }\end{array}$ & $\begin{array}{l}\text { LEP/ } \\
1984\end{array}$ \\
\hline ECA & Artigo $9^{\circ}$ & $\begin{array}{c}\text { Lei } \\
13.257 / \\
2016 \\
\end{array}$ & --- & --- & Artigo $8^{\circ}$ & $\begin{array}{c}\text { Lei } \\
13.257 / \\
2016 \\
\end{array}$ & --- & --- & --- & --- & --- & --- & --- & --- \\
\hline $\mathrm{CP}$ & --- & --- & Artigo 37 & $\begin{array}{c}\text { Lei } \\
7.209 / \\
1984 \\
\end{array}$ & --- & --- & --- & --- & --- & --- & --- & --- & --- & --- \\
\hline CPP & --- & --- & Artigo 766 & $\begin{array}{l}\text { CPP/ } \\
1941\end{array}$ & --- & --- & --- & --- & $\begin{array}{c}\text { Artigo } 318, \\
\text { IV e V }\end{array}$ & $\begin{array}{c}\text { Lei } \\
13.257 / \\
2016\end{array}$ & $\begin{array}{c}\text { Artigo } 292, \\
\text { PU }\end{array}$ & $\begin{array}{c}\text { Lei } \\
13.434 / \\
2017\end{array}$ & --- & --- \\
\hline
\end{tabular}

Recomendações, tratados

ou convenções de âmbito internacional

Convenção de Belém do Pará Regras de Bangkok 


\section{Capítulo IV - O Benefício à Prisão Domiciliar da Mulher perante o Direito do Filho à uma Infância Livre}

Augusto Thompson, em "A Questão Penitenciária"77, demonstra que o sistema penitenciário é repleto de falhas e seu destino está necessariamente fadado ao fracasso. Sua análise crítica advém da instituição como fator criminológico por si só somado ao colapso de sua gestão interna.

O primeiro argumento do livro que podemos mencionar é a existência de fins contraditórios atribuídos à pena de prisão. Na teoria, a pena possui metas formais determinadas concomitantes, tais quais: punição pelo mal causado, prevenção da prática de novas infrações e regeneração do preso. Entretanto, comprova-se por praticamente impossível a harmonização desta tríplice, tendo em vista que os critérios de punir e reeducar trazidos pela Lei de Execução Penal se encontram como antagônicos.

Além disso, sabe-se que a prisão é considerada um sistema social em apartado muito peculiar. Os presos são separados da sociedade livre pelo muro da prisão, ficando lá dentro despidos de autonomia e definidos como uma classe moralmente inferior de pessoas. Por consequência, internamente acaba ocorrendo uma assimilação de cultura prisional. Dentro deste contexto, o processo de prisonização ${ }^{78}$ abarca não só aos presos como a todos os envolvidos, inclui-se aqui a direção, a guarda e os terapeutas. Cada um desses indivíduos é moldado por um ambiente imerso em relações de poder, submissão e troca de favores para fazer funcionar a engrenagem da máquina prisional.

\footnotetext{
77 THOMPSON, Augusto. Op. Cit., p. 145.

${ }^{78}$ Augusto Thompson utiliza o termo "prisonização" em seu livro A Questão Penitenciária, entretanto, nos dias atuais houve a adaptação desta palavra para "prisionização" pelos autores contemporâneos. Pode-se citar como exemplo ilustrativo a obra: DE SÁ, Alvino Augusto, Criminologia Clínica e Psicologia Criminal, $2^{\text {a }}$ ed. rev., atual. e ampl. - São Paulo: Editora Revista dos Tribunais, 2013. Desta maneira, pode aparecer de uma forma ou de outra, mas ambas estão corretas e se referem ao mesmo fenômeno.
} 
Há, portanto, um abismo enorme entre a teoria e a prática, considerando que o sistema carcerário evidencia falta de recursos financeiros e humanos, superlotação, violência, entre outros problemas. Diante deste cenário, evitar desordem e o impedimento de fugas tornam-se prioridades. Quando os meios acabam se tornando os fins, a meta de ressocialização fica completamente esquecida.

Uma vez o sujeito encarcerado, parte-se do pressuposto que este será corrigido na prisão e que quando sair estará apto à convivência social. Esta, entretanto, não é a realidade que é vista: os modos e regras da sociedade carcerária são totalmente distintos dos da sociedade comum. Então, o indivíduo sai da cadeia sem a adaptação necessária e isso explica, muitas vezes, a quantidade alarmante de casos de reincidência.

Embora o referido estudo de "A Questão Penitenciária" tenha sido publicado nos tempos longínquos de 1976, pode-se compreender que grande parte da pesquisa de Thompson é de se encaixar 42 anos mais tarde, em cenário contemporâneo, confirmando assim sua premissa. Nas palavras do autor:

[...] a questão penitenciária não tem solução "em si", porque não se trata de um problema "em si", mas parte integrante de outro maior: a questão criminal, com referência ao qual não desfruta qualquer autonomia. A seu turno, a questão criminal também nada mais é que mero elemento de outro problema mais amplo: o das estruturas sóciopolítico-econômicas. Sem mexer nestas, coisa alguma vai alterar-se em sede criminal e, menos ainda, na área penitenciária. ${ }^{79}$

\subsection{A questão penitenciária sob a ótica feminina}

A análise que o autor Augusto Thompson faz é única e exclusivamente sob a perspectiva individual e pessoal do encarcerado. Entretanto, uma vez que alguém perde sua liberdade e é submetido ao sistema prisional, reflexos são

\footnotetext{
${ }^{79}$ THOMPSON, Augusto. Op. cit., p. 110.
} 
propagados em uma gama de áreas de sua vida, seja ela pessoal, familiar, profissional, social, entre outras.

No caso da mulher, como aludido e explicado nas exposições temáticas anteriores, quando isto ocorre, todos os membros da família são diretamente afetados e seu vínculo é quebrado. É alarmante o fato de que $80 \%$ das mulheres presas são mães e responsáveis principais pelo zelo de seus filhos - a figura paterna é tida como ausente na maioria dos casos -, conforme informação fornecida pelo último relatório do Departamento Penitenciário Nacional $(\mathrm{DEPEN})^{80}$, órgão este do Ministério da Justiça.

Em 2008, por exemplo, as Universidades de Princeton e Columbia nos Estados Unidos por meio dos institutos de pesquisa Bendheim-Thomam Center for Research on Child Wellbeing e Columbia Population Research Center fizeram um estudo sobre a relação causal entre o encarceramento parental e os efeitos negativos enfrentados na vida e no bem-estar de seus filhos. ${ }^{81}$

A análise utiliza dados do Fragile Families Study, um estudo nacional que segue um corte de crianças nascidas entre 1998 e 2000 (cerca de 4.898 no total) e seus pais em vinte cidades dos Estados Unidos (não há menção a quais). Os genitores são entrevistados pela primeira vez em torno do nascimento de seus filhos e depois reentrevistados em torno dos primeiros, terceiro e quinto aniversários das crianças.

Os estudos demonstraram que crianças com pais enfrentando o encarceramento tendem a viver em ambientes de alto risco, tendo em vista três grandes categorias principais: instabilidade familiar, problemas de desenvolvimento ou carência de necessidades básicas.

Com base nisto, o presente capítulo irá abordar sobre uma medida

\footnotetext{
${ }^{80}$ BRASIL. Dados Consolidados. Op. cit, p. 14. Disponível em: <http://www.justica.gov.br/news/estudo -traca-perfil-da-populacao-penitenciaria-feminina-no-brasil/relatorio-infopen-mulheres.pdf $>\quad$ Acesso em: 20 de mar. 2018.

${ }^{81}$ Os resultados do estudo "Parental Incarceration and Child Wellbeing in Fragile Families" estão Disponível em: 〈https://fragilefamilies.princeton.edu/sites/fragilefamilies/files/researchbrief42.pdf〉 Acesso em: 06 de mar. 2018.
} 
substitutiva ao encarceramento prisional, buscando casos concretos que possam servir como base argumentativa.

\subsection{As mulheres encarceradas e o advento da Lei 13.257/2016}

Diante da realização de coleta de dados e levantamento de estatísticas no Capítulo 2, pode-se aferir o Brasil como a quarta maior população carcerária feminina do mundo. Lá dentro é possível encontrar não só mulheres já sentenciadas, como também as que simplesmente esperam julgamento, em situação de prisão preventiva ou temporária.

Sabe-se que estas além de enfrentar situações diárias de violência e violação de seus direitos, também precisam conviver com a dor que a distância proporciona de estarem longe e não poderem criar seus filhos.

Em plena análise da perspectiva brasileira, sabe-se que o Código Penal não é instrumento único para cumprimento da lei. Como já desenvolvido no Capítulo 3, existem outros dispositivos que deveriam ser contemplados e respeitados para atingir a justiça social esperada, principalmente no que tange à regulamentação dos direitos humanos e à questão de gênero.

O objeto em pauta que será aqui evidenciado é o advento recente da Lei 13.257 de 2016, ${ }^{82}$ também chamada de Estatuto da Primeira Infância, cujo objetivo de políticas públicas para bebês e crianças reflete em alterações de diversos diplomas legais, tais quais o Código de Processo Penal, o Estatuto da Criança e do Adolescente, a Consolidação das Leis Trabalhistas e a Lei 11.770/2008. Isso pode ser explicado devido a cautela específica e significativa

\footnotetext{
${ }^{82}$ É de bom tom salientar o motivo pelo qual a respectiva estar em apartado do levantamento das legislações com recorte de gênero elaborado no capítulo antecedente: esta possui um intuito diferente, pois o bem jurídico tutelado é a preservação dos direitos e interesses de um indivíduo menor de idade em situação de vulnerabilidade que surge com a segregação do único responsável pelos seus cuidados, perpassando, assim, a conjuntura da própria mulher encarcerada.
} 
dos primeiros anos de vida no quesito de crescimento infantil e desenvolvimento humano. ${ }^{83}$

O foco da discussão será com base nas mudanças trazidas pela lei no Código de Processo Penal, nosso objeto de estudo. Vale ressaltar que apesar das alterações e acréscimos terem ocorrido em quatro artigos: $6^{\circ}, 185,304$ e 318, dar-se-á mais ênfase ao último, considerando sua maior relevância relacionado à política de desencarceramento aqui defendida.

\subsubsection{As modificações produzidas pela Lei $13.257 / 2016$ ao Código de Processo Penal (âmbito geral)}

$\mathrm{O}$ artigo $6^{\circ}$ do aludido Código elenca minusciosamente em inúmeros incisos o procedimento pelo qual a autoridade policial deve percorrer ao ter conhecimento da prática de ato criminoso. A Lei 13.257/16 acrescenta o inciso X, o qual impõe a obrigação do Delegado de Polícia a averiguar a existência de filhos menores impúberes, assim como adentrar no mérito de quem poderia ser o eventual responsável pelos cuidados deles durante sua ausência.

Em caso afirmativo do respectivo questionamento, deve-se proceder conforme o novo $\S^{\circ}$ do artigo 304 e registrar tal informação no auto de prisão em flagrante para que a referência conste lá expressamente.

Seguindo o mesmo viés, o artigo 185 trata de forma descritiva as providências que devem ser tomadas pelo magistrado ao longo do interrogatório do acusado. E da mesma forma, a Lei 13.257/16 amplifica o rol com o inciso X, provocando o dever legal do juiz questionar a pessoa sobre a existência de filhos menores impúberes, assim como adentrar no mérito de quem poderia ser o eventual responsável pelos cuidados deles durante sua ausência.

\footnotetext{
${ }^{83}$ CEDES. Avanços do Marco Legal da Primeira Infância. Brasília: Caderno de Trabalhos e Debates 1, 2016. p. 25-29. Disponível em: <http://www2.camara.leg.br/a-camara/estruturaadm/altosestudos/ pdf/obra-avancos-do-marco-legal-da-primeira-infancia> Acesso em: 02 de jun.2018.
} 
Portanto, é de se assimilar, de forma geral, que estes três primeiros dispositivos legais têm por objetivo garantir o colhimento e registro de informação no que diz respeito a quesitos meramente processuais em si perante ao tema: qualificação do indiciado, autuado e acusado nos respectivos trâmites de inquérito policial, auto de prisão em flagrante e processo judicial.

Após perpassar ordinários méritos de oficialidade, chega-se finalmente ao ponto sensível da alteração legislativa: as novas hipóteses de cabimento da substituição da pena de prisão preventiva pela domiciliar do artigo 318 do Código de Processo Penal nos incisos IV, V e VI.

Antes de adentrar ao quesito das modificações e acréscimos na lei, será examinado o conceito em si.

\subsection{Conceito de prisão domiciliar}

A definição de prisão domiciliar, perante o artigo 317 do Código de Processo Penal, exprime a própria denominação que lhe é atribuída, qual seja, o réu tem a possibilidade de sua pena privativa de liberdade ser restrita meramente ao âmbito de sua residência ao invés de permanecer na instituição em status de prisão preventiva ou temporária.

Este benefício possui compleição de medida provisória, cuja natureza processual é tida como medida cautelar. Entretanto, não é considerada medida alternativa à prisão da lista do artigo 319 , mas sim substitutiva e por isso, possui artigos em apartado. Como explica o mestre Fernando da Costa Tourinho Filho:

[...] a prisão domiciliar se inclui no rol das medidas cautelares, e só não poderia estar abrangida no elenco daquelas previstas no corpo do art. 319 porque ali se fala em "medidas cautelares diversas da prisão". E o confinamento, mesmo na residência do indiciado ou réu, 
não deixa de ser prisão, ante a impossibilidade de maior liberdade de locomoção [...]. ${ }^{84}$

Em tempo, importante ressaltar que o instituto da prisão domiciliar abarca não só a espécie de natureza cautelar, objeto este de estudo da prisão preventiva pelo artigo 318 do Código de Processo Penal, mas também aquela de natureza definitiva, no caso de condenação com cumprimento de pena no regime aberto pelo artigo 117 da Lei de Execução Penal diante, claro, do preenchimento dos pressupostos legais, tais quais:

Art. 117. Somente se admitirá o recolhimento do beneficiário de regime aberto em residência particular quando se tratar de:

I - condenado maior de 70 (setenta) anos;

II - condenado acometido de doença grave;

III - condenada com filho menor ou deficiente físico ou mental;

IV - condenada gestante.

\subsection{As modificações produzidas pela Lei $13.257 / 2016$ especificamente ao artigo 318 do Código de Processo Penal}

As modificações do Capítulo IV do Código de Processo Penal contaram com a alteração do texto para as mulheres gestantes e a inclusão tanto da condição das mulheres com filhos de até 12 anos de idade incompletos, quanto da condição dos homens, caso seja único responsável pelos cuidados do filho de até 12 anos de idade incompletos no rol do artigo.

Em se tratando do caso das mulheres gestantes, houve um grande avanço com relação a redação do dispositivo anterior, dado que foram retiradas as circunstâncias de tempo de gestação e/ou de sua situação de saúde, consoante a Tabela 5 a seguir:

\footnotetext{
${ }^{84}$ FILHO, Fernando da Costa Tourinho. Manual de Processo Penal. $16^{\mathrm{a}}$ edição, revista e atualizada. São Paulo: Saraiva, 2013. p. 697.
} 
Tabela 5 - Quadro comparativo artigo 318, inciso IV CPP: texto anterior e posterior à alteração advinda da Lei 13.257/2016.

\begin{tabular}{|l|l|}
\hline \multicolumn{3}{|c|}{ CPP } \\
\hline Antes da Lei 13.257/2016 & \multicolumn{1}{|c|}{ Atualmente } \\
\hline $\begin{array}{l}\text { Art. 318. Poderá o juiz } \\
\text { substituir a prisaro 318. Poderá o juiz } \\
\text { preventiva pela domiciliar } \\
\text { quando o agente for: }\end{array}$ & $\begin{array}{l}\text { Artibstituir a a prisão } \\
\text { preventiva pela domiciliar } \\
\text { quando o agente for: }\end{array}$ \\
$\begin{array}{l}\text { IV-gestante a partir do } 7^{\circ} \\
\text { (sétimo) mês de gravidez } \\
\text { ou sendo esta de alto risco. }\end{array}$ & IV-gestante; \\
\hline
\end{tabular}

Destarte, basta que ela esteja grávida para que possa cumprir a temporada de prisão cautelar no recolhimento de seu lar. Não há muito o que discutir sobre isso.

Na segunda esfera, temos uma questão polêmica que será tratada no próximo tópico no que se refere aos dois novos incisos subsequentes. Ambos não existiam anteriormente e foram incluídos pelo Estatuto da Primeira Infância (Lei 13.257/2016), nos seguintes textos:

Art. 318. Poderá o juiz substituir a prisão preventiva pela domiciliar quando o agente for:

$[\ldots]$

$\mathrm{V}$ - mulher com filho de até 12 (doze) anos de idade incompletos;

VI - homem, caso seja único responsável pelos cuidados do filho de até 12 (doze) anos de idade incompletos;

Importante salientar que todas as "novas regras" podem ser aplicadas de prontidão aos presentes processos em curso assim como às presas que tenham cometido o crime antes de sua vigência. A justificativa se dá perante o caráter processual da norma da Lei 13.257/2016 e pelo retrocesso benéfico da norma 
penal respectivamente, conforme artigo $2^{\circ}$ do Código de Processo Penal, artigo $2^{\circ}$ do Código Penal e artigo $5^{\circ}$, XL da Constituição Federal.

\subsection{Críticas às novas regras aplicadas à prisão domiciliar}

\subsubsection{Análise crítica à generalização da benesse prevista em lei}

Em avaliação preliminar, é de suma importância compreender a implicação do vocabulário "poderá" no caput do artigo 318: em matéria de Teoria do Direito, a postura axiológica no Brasil admitida é que, em certas circunstâncias, os limites semânticos são tidos como arcaicos em nome dos próprios valores estampados naquele dispositivo legal. Desta forma, o vocábulo "pode" pode ser percebido como "deve", como ocorre por exemplo no artigo 89 da Lei $9.099 / 95^{85}$. Ou seja, no sentido de obrigação e poder-dever do magistrado. ${ }^{86}$

A crítica da doutrina com relação a este debate tem por base a análise das peculiaridades do caso concreto. Logo, existem requisitos objetivos e subjetivos a serem preenchidos para a substituição da prisão preventiva em prisão domiciliar.

Isso significa que a concessão à medida substitutiva não ocorre de forma meramente automática quando a situação do agente se encaixar em alguma das hipóteses do artigo 318. Também é necessário a realização do juízo positivo do magistrado acerca dos elementos da conduta do agente que reforçam que tal substituição se dê por necessária, adequada e suficiente. Caso não preencha tais

\footnotetext{
${ }^{85}$ Art. 89. Nos crimes em que a pena mínima cominada for igual ou inferior a um ano, abrangidas ou não por esta Lei, o Ministério Público, ao oferecer a denúncia, poderá propor a suspensão do processo, por dois a quatro anos, desde que o acusado não esteja sendo processado ou não tenha sido condenado por outro crime, presentes os demais requisitos que autorizariam a suspensão condicional da pena (grifo meu).

${ }^{86}$ TRIBE, Laurence; Dorf, Michael. Hermenêutica Constitucional. Tradução de Amarílis de Souza Birchal; Coordenação e supervisão de Luiz Moreira. Belo Horizonte: Del Rey, 2007. p. 19.
} 
contornos concomitantes, não será possível o direito ao benefício. Deste modo, nas palavras de Alexandre Cebrian e Victor Gonçalves:

De ver-se, entretanto, que a substituição da prisão preventiva pela domiciliar constitui mera faculdade do juiz, não sendo obrigatória. Com efeito deve sempre prevalecer a defesa da coletividade em detrimento das pretensões particulares, de modo que não é aceitável que o indiciado ou réu com considerável periculosidade possa usufruir, automaticamente, do benefício em questão, durante o tramitar das investigações ou da ação, apenas pelo fato de ser responsável por menor de 6 anos ou pessoa deficiente, por exemplo (...). Se a prisão domiciliar fosse obrigatória em tais casos, o agente teria uma espécie de imunidade. É claro, portanto, que os juízes devem interpretar tal dispositivo com cautela, recordando-se sempre que é dever do Estado proteger a sociedade, uma vez que o constituinte consagrou no art. 5. $^{\circ}$, caput, da Carta Magna o direito à vida, à segurança, à liberdade etc. Dessa forma, conclui-se que o criminoso responsável por criança menor de 6 anos ou por pessoa deficiente não tem direito subjetivo a cumprir prisão preventiva em domicílio, podendo o juiz determinar que o indiciado ou réu permaneça no cárcere quando entender que sua periculosidade extremada justifica o indeferimento da prisão domiciliar ou quando entender que há grande risco às testemunhas ou de fuga etc. ${ }^{87}$

\section{Outro autor que partilha da opinião acima citada é Renato Brasileiro e}

diz que:

(...) a presença de um dos pressupostos indicados no art. 318, isoladamente considerado, não assegura ao acusado, automaticamente, o direito à substituição da prisão preventiva pela domiciliar.

O princípio da adequação também deve ser aplicado à substituição (CPP, art. 282, II), de modo que a prisão preventiva somente pode ser substituída pela domiciliar se se mostrar adequada à situação concreta. Do contrário, bastaria que o acusado atingisse a idade de 80 (oitenta) anos, por exemplo, para que tivesse direito automático à prisão domiciliar, com o que não se pode concordar. Portanto, a presença de um dos pressupostos do art. 318 do CPP funciona como requisito mínimo, mas não suficiente, de per si, para a substituição, cabendo ao magistrado verificar se, no caso concreto, a prisão domiciliar seria suficiente para neutralizar o periculum

\footnotetext{
${ }^{87}$ CEBRIAN, Alexandre e GONÇALVES, Victor. Direito Processual Penal Esquematizado. $2^{\mathrm{a}}$ edição. São Paulo: Saraiva, 2013. p. 396.
} 
libertatis que deu ensejo à decretação da prisão preventiva do acusado. ${ }^{88}$

Estes entendimentos se aplicam de igual modo às novas hipóteses de prisão domiciliar após a Lei 13.257/2016.

À esta crítica, no que concerne à jurisprudência, dois julgados do Superior Tribunal de Justiça (STJ) perante o tema foram selecionados como viés exemplificativo:

A previsão insculpida na lei reformadora do art. 318 do Código de Processo Penal não é de caráter puramente objetivo e automático, cabendo ao magistrado avaliar em cada caso concreto a situação da criança e, ainda, a adequação da benesse às condições pessoais da presa. $^{89}$

$\mathrm{O}$ inciso III do art. 318 do CPP, introduzido pela Lei $\mathrm{n}$. 12.403/2011, bem como o inciso V do mesmo artigo, introduzido pela Lei n. 13.257/2016, não trouxeram maiores detalhamentos sobre os requisitos subjetivos a serem atendidos para conversão da prisão preventiva em domiciliar. No caput do art. 318 do Código de Processo Penal encontra-se a previsão de que o Juiz poderá converter a prisão preventiva em domiciliar. Dessa forma, essa análise deve ser feita caso a caso, pois se por um lado não existe uma obrigatoriedade da conversão, por outro a recursa também deve ser devidamente motivada. O requisito objetivo está atendido, uma vez que a paciente é mãe de criança de 4 anos de idade, acometida por "atraso no desenvolvimento da marcha", distúrbio no qual a criança apresenta quadros de crises convulsivas, sendo necessário o acompanhamento da genitora (dados comprovados por meio da certidão de nascimento e relatório médico acostados aos autos). No tocante ao preenchimento dos requisitos subjetivos, ainda que se trate de crime equiparado a hediondo, pesa em favor da paciente o fato de se tratar de acusada primária, com bons antecedentes e residência fixa. Assim, considerando que a presente conduta ilícita se trata de fato isolado na vida da paciente, acrescido ao fato de que até o momento da prisão era ela a responsável pela

${ }^{88}$ BRASILEIRO, Renato. Manual de Direito Processual Penal. 3a edição. Salvador: Juspodivm, 2015. p. 998.

${ }^{89}$ STJ. Recurso em Habeas Corpus no 83.488/SP, Min. Relator: Jorge Mussi, julgado em 23/05/2017. Disponível em: <https://stj.jusbrasil.com.br/jurisprudencia/46785122 2/recurso-ordinario-em-habeascorpus-rhc-83488-sp-2017-0091583-9/inteiro-teor-467851235\#> Acesso em: 31 de mar. 2018. 
guarda, criação e orientação das menores, mostra-se adequada a conversão da custódia cautelar em prisão domiciliar. ${ }^{90}$

Outro argumento crítico da doutrina e jurisprudência em relação a novidade legislativa que alterou partes do Código de Processo Penal, e que pode gerar mais polêmica ainda, é a comparação entre os incisos V e VI do aludido artigo. As normas são basicamente idênticas, excetuando-se dois fatores: o gênero do agente contemplado e a ausência/presença do termo "caso seja o único responsável pelos cuidados do filho".

Ainda que o inciso relacionado à mulher não possua esta condicionante expressa em seu texto, como faz o seguinte referente ao homem, é primordial a realização de uma análise conglobante. Isso se dá, pois, o Direito existe de forma estrutural, ordenada e sincrônica. Logo, a norma não pode ser vista de forma isolada, mas sim mediante interpretação sistemática. Nas palavras articuladas de Carlos Maximiliano:

Consiste o Processo Sistemático em comparar o dispositivo sujeito a exegese com outros do mesmo repositório ou de lei diversas, mas referentes ao mesmo objeto. ${ }^{91}$

Isto posto, leia-se que em sede do preenchimento dos requisitos formais da referida hipótese legal, o agente para gozar do benefício necessita não só atender o critério de possuir filho com até 12 (doze) anos de idade incompletos, mas também, cumulativamente, ser o único responsável pelos seus cuidados.

A concepção de "responsável pelos cuidados do filho" deve ser entendida como a mistura do exercício do poder familiar combinado com as obrigações

\footnotetext{
${ }^{90}$ STJ. Habeas Corpus no 394.039/SP, Min. Relator: Joel Ilan Paciornik, julgado em 23/05/2017. Disponível em: <https://stj.jusbrasil.com.br/jurisprudencia/468929794 /habeas-corpus-hc-394039-sp2017-0070368-0/inteiro-teor-468929795?ref=juris-tabs\#> Acesso em: 31 de mar. 2018.

${ }^{91}$ MAXIMILIANO, Carlos. Hermenêutica e Aplicação do Direito. $20^{\mathrm{a}}$ edição. Rio de Janeiro: Forense, 2011. p. 104.
} 
decorrentes da guarda, conforme dispositivos legais do Código Civil e Estatuto da Criança e do Adolescente, respectivamente, a seguir:

Art. 1.634. Compete a ambos os pais, qualquer que seja a sua situação conjugal, o pleno exercício do poder familiar, que consiste em, quanto aos filhos:

I - dirigir-lhes a criação e a educação;

II - exercer a guarda unilateral ou compartilhada nos termos do art. 1.584 ;

III - conceder-lhes ou negar-lhes consentimento para casarem;

IV - conceder-lhes ou negar-lhes consentimento para viajarem ao exterior;

$\mathrm{V}$ - conceder-lhes ou negar-lhes consentimento para mudarem sua residência permanente para outro Município;

VI - nomear-lhes tutor por testamento ou documento autêntico, se o outro dos pais não lhe sobreviver, ou o sobrevivo não puder exercer o poder familiar;

VII - representá-los judicial e extrajudicialmente até os 16 (dezesseis) anos, nos atos da vida civil, e assisti-los, após essa idade, nos atos em que forem partes, suprindo-lhes o consentimento;

VIII - reclamá-los de quem ilegalmente os detenha;

IX - exigir que lhe prestem obediência, respeito e os serviços próprios de sua idade e condição.

Art. 33. A guarda obriga a prestação de assistência material, moral e educacional à criança ou adolescente, conferindo a seu detentor o direito de opor-se a terceiros, inclusive aos pais.

Diante disso, pode ser compreendido que este "responsável" é todo aquele que assume, sozinho, a criação da criança, assim como, garante o devido assessoramento educacional, moral e material para seu íntegro desenvolvimento humano.

Isso significa dizer que é necessário observar se o agente opera efetivamente como único responsável pelos cuidados do filho, a fim de se preservar a disciplina das prisões cautelares e evitar a deturpação pelo automatismo da substituição da prisão preventiva por prisão domiciliar a todo aquele que possua descendente de até doze anos incompletos.

Por fim, ante os argumentos supracitados, conclui-se que as críticas enunciadas, realizadas tanto no campo teórico pela doutrina quanto reafirmadas 
pela jurisprudência na prática por meio dos julgados, têm como principal apreensão a generalização da benesse previsto no artigo 318 do Código de Processo Penal, nas situações em que tal prerrogativa não pareça devidamente fundada. Ou seja, discernimentos amplos que confrontem a arbitrariedade, culminando assim, na desvalorização da significativa novidade legislativa oferecida pela Lei 13.257/2016.

\subsubsection{Análise crítica em prol do interesse maior da criança e do incentivo à uma política de desencarceramento}

Despejou o leite devagarinho no copo de café, curtindo cada gota que caía com aquela satisfação que as pessoas sentem quando veem o mar pela primeira vez, conhecem o amor de suas vidas ou descobrem que se curaram de uma doença grave. Depois de quase seis anos, era a primeira vez que Safira podia fazer o café da manhã dos dois filhos - um de seus desejos imediatos na sua primeira saída do presídio no regime semiaberto.

Colocou os copos na mesa, sorridente. Um dos meninos olhou aquilo com estranheza.

- Mas você não sabe, mãe, que a gente não toma café, só toma Toddy?

A frase caiu sobre ela com o peso dos anos perdidos. Em sete anos de prisão, chegara a ficar três sem vê-los. Perdeu o primeiro dia de aula, a primeira vez que andaram de bicicleta. $\mathrm{O}$ mais velho, de 13 anos, já tinha até uma namorada.

Eu não conheço os meus filhos. Eu sou assim: eles sabem que eu sou a mãe deles, mas praticamente sou uma desconhecida. Além de eu ter que me adaptar às coisas que eu perdi todo esse período que estive presa, eu tenho que aprender a conhecer os MEUS filhos", pensou. ${ }^{92}$

Assim começa o livro "Presos que menstruam" da jornalista Nana Queiroz que ouviu e deu voz às mulheres encarceradas e suas famílias. Logo à primeira vista é possível observar um dos reflexos mais significativos do sistema prisional: a violação de direitos de mães e seus filhos.

${ }^{92}$ QUEIROZ, Nana. Op. cit., p. 21/22. 
A história de Safira é parecida com a de outras milhares de mulheres presas no país, as quais tiveram seus vínculos familiares brutalmente cortados e, afastadas não só da sociedade no geral, mas por tabela da criação de seus filhos.

Diversas pesquisas científicas da área da Psicologia ${ }^{93}$ afirmam que os primeiros anos de vida da criança (período este que comporta desde o nascimento até os seis anos de idade) possuem especial importância, posto que esta é a época primordial de sua formação e desenvolvimento, e por consequência, reflexo direto no futuro daquele ser humano. Importante mencionar que estes são influenciados pelo ambiente no qual ela se encontra, assim como aos estímulos a ela auferidos.

O âmbito familiar é considerado um dos grandes alicerces para o desenvolvimento infantil. Juntamente com o papel que a escola desempenha, os laços familiares são capazes de potencializar as habilidades cognitivas das crianças, ensinar sobre relações sociais e amor e, igualmente, proporcionar as condições materiais necessárias à sua sobrevivência.

Desta forma, sem sombra de dúvidas, o Estatuto da Primeira Infância foi um marco legal a se comemorar, tendo em vista a preocupação de políticas públicas referentes ao bem-estar de bebês e crianças.

Contudo, é de se lastimar a proporção do crescimento do encarceramento feminino e, concomitantemente, a desvalorização dos dispositivos legais existentes em benefício destas mulheres e seus filhos na grande maioria das decisões judiciais.

As normas garantidoras existem, mas não são aplicadas da forma como deveriam e prisões cautelares perdem sua essência de prisão sem pena ao adquirir formatos tendenciosos. Desta forma, a aplicação desta medida pelos juízes de maneira generalizada e arbitrária, por trás do véu da subjetividade das

\footnotetext{
${ }^{93}$ Um exemplo de pesquisa a ser citada é a do TERRA, Osmar. A importância dos primeiros anos de vida. Revista de Informação Legislativa A 44, no 176. Brasília, 2007, p. 95-97. Disponível em: <https://www12.senado.leg.br/ril/edicoes/44/176/ril_v44_n176_p95.pdf> Acesso em: 10 de mar. 2018.
} 
lacunas legais, é somente um meio para saciar a angústia de sensação de segurança da sociedade diante da violência e caos instaurados no país. ${ }^{94}$

Vale ressaltar que a importância da existência do artigo $5^{\circ}$, inciso LXI da Constituição Federal, que dispõe que "ninguém será preso senão em flagrante delito ou por ordem escrita e fundamentada da autoridade judicial competente, salvo nos casos de transgressão militar ou crime propriamente militar". Esta garantia constitucional é fruto do trauma deixado pelo período da Ditadura Militar no Brasil que tinha por seu feitio executar prisões discricionárias. Por isso, a necessidade de decisões por autoridade judiciária terem sido preconizadas na Carta Magna de $1988 . .^{95}$

As prisões cautelares devem ter caráter de excepcionalidade, pois não defluem nem sequer de uma condenação. Logo, deve ser operada apenas como a ultima ratio. ${ }^{96} \mathrm{Ou}$ seja, se existirem outras medidas tão eficazes quanto para atingir aquele fim, estas devem ser priorizadas, enquanto a restrição da liberdade se tem como último instrumento estatal.

Não obstante tais parâmetros legais, ainda assim é de se observar a quantidade de decisões, na maioria das vezes desnecessárias, baseadas em fundamentações do artigo 312 do Código de Processo Penal para emprego da respectiva prisão preventiva ou do artigo $1^{\circ}$ da Lei 7.960/1989 para proveito da prisão temporária (modalidades estas de prisões cautelares mencionadas por serem as mais corriqueiras). O resultado é a superlotação dos institutos prisionais compostos em sua grande maioria de presos ainda não definitivamente condenados.

Em outras palavras, os argumentos de garantia da ordem pública, garantia da ordem econômica, por conveniência da ordem criminal ou para assegurar a

\footnotetext{
${ }^{94}$ WENDY, Miguel Tedesco. Teoria Geral da Prisão Cautelar e Estigmatização. Rio de Janeiro: Editora Lumen Juris, 2006. p. 163.

${ }^{95}$ SOUZA, José Barcelos. A Renovação Processual Penal após a Constituição de 1988. Rio de Janeiro: Editora Lumen Juris, 2009. p. 102.

${ }^{96}$ FERRAJOLI, Luigi. Direito e Razão: teoria do garantismo penal. Tradução: Ana Paula Zomer, Fauzi Hassan Chower, Juarez Tavares e Luiz Flávio Gomes. São Paulo: Revista dos Tribunais, 2002. p. 446.
} 
aplicação da lei penal do artigo 312 do CPP ou a imprescindibilidade da prisão para as investigações do inquérito policial, a falta de residência fixa ou identidade não esclarecida ou fundada razão de autoria ou participação do indiciado nos crimes lá listados no artigo $1^{\circ}$ da Lei 7.960/1989, sobretudo o de tráfico de drogas, são utilizados de forma trivial e mecânica, sem se preocupar com as peculiaridades que circundam o caso concreto.

Individualidades estas que no quadro em comento do respectivo capítulo se referem à infância livre. Isto é, não deixar que as crianças de mães presas sejam fadadas ao destino do abandono e descaso, quando existem alternativas plausíveis para este problema. Desta forma, os magistrados ao optarem pela não concessão do benefício da prisão domiciliar violam preceitos legais aos quais alguns serão enumerados a seguir:

Art. $5^{\circ}$. Todos são iguais perante a lei, sem distinção de qualquer natureza, garantindo-se aos brasileiros e aos estrangeiros residentes no País a inviolabilidade do direito à vida, à liberdade, à igualdade, à segurança e à propriedade, nos termos seguintes:

[...]

XLV - nenhuma pena passará da pessoa do condenado, podendo a obrigação de reparar o dano e a decretação do perdimento de bens ser, nos termos da lei, estendidas aos sucessores e contra eles executadas, até o limite do valor do patrimônio transferido;

$\mathrm{O}$ artigo $5^{\circ}$, inciso XLV da Constituição Federal preceitua o princípio constitucional da intranscendência da pena. Isto é, nenhuma pessoa pode ser obrigada a cumprir pena por um ato praticado por outrem.

Art. 19. É direito da criança e do adolescente ser criado e educado no seio de sua família e, excepcionalmente, em família substituta, assegurada a convivência familiar e comunitária, em ambiente que garanta seu desenvolvimento integral. 
O artigo 19 da Lei 8.069/1990 (Estatuto da Criança e do Adolescente) tem por objetivo garantir integral desenvolvimento da criança pelo direito de ser educada pela própria família.

Art. 13. A União, os Estados, o Distrito Federal e os Municípios apoiarão a participação das famílias em redes de proteção e cuidado da criança em seus contextos sociofamiliar e comunitário visando, entre outros objetivos, à formação e ao fortalecimento dos vínculos familiares e comunitários, com prioridade aos contextos que apresentem riscos ao desenvolvimento da criança.

O artigo 13 da Lei 13.257/2016, mais conhecido como Estatuto da Primeira Infância, possui o intuito de valorizar os vínculos familiares e comunitários.

Art. 227. É dever da família, da sociedade e do Estado assegurar à criança, ao adolescente e ao jovem, com absoluta prioridade, o direito à vida, à saúde, à alimentação, à educação, ao lazer, à profissionalização, à cultura, à dignidade, ao respeito, à liberdade e à convivência familiar e comunitária, além de colocá-los a salvo de toda forma de negligência, discriminação, exploração, violência, crueldade e opressão.

Todos os artigos anteriormente citados estando em consonância máxima com o artigo 227 da Constituição Federal, que tem por função tratar a criança como prioridade absoluta e, igualmente, a garantia dos seus direitos, na qual o melhor interesse para esta deva sempre prevalecer.

Conclui-se então que as decisões que suportam a restrição de liberdade de mulheres em um plano geral, como demonstrado ao longo de todo o presente capítulo, geram um impacto avassalador na vida das crianças envolvidas por trás de suas mães. A consciência e cautela com a infância é incumbência repartida entre a família, o Estado e a coletividade como um todo.

Por isso, é de suma importância o incentivo à uma política de desencarceramento, assim como, a eficácia da aplicação dos direitos das 
mulheres presas específicos de seu gênero e a concessão de benefícios para as que se enquadrem nas hipóteses legais, principalmente no que se refere à prisão domiciliar, como será visto no próximo tópico relacionado a três casos concretos de decisões que se tornaram exemplos a serem seguidos no judiciário.

\subsection{Casos concretos emblemáticos}

\subsubsection{Caso Adriana Ancelmo}

Faz-se necessário um breve resumo cronológico para a compreensão do contexto como um todo do emblemático caso em questão: Adriana Ancelmo, ex-primeira dama do Rio de Janeiro, presa pela Operação Calculite, deflagrada pela Polícia Federal sob a alegação de associação criminosa e lavagem de dinheiro. Por sua vez, presa preventivamente a primeira vez em 06 de dezembro de 2016, por meio da Medida Cautelar no 0510203-33.2016.4.02.5101, pelo juiz Marcelo Bretas da $7^{\text {a }}$ Vara Federal Criminal do Rio de Janeiro, este responsável pelos processos penais na Operação Lava Jato ${ }^{97}$. Vale lembrar que, posteriormente, fora oferecida denúncia pelo Ministério Público Federal, Ação Penal esta de $\mathrm{n}^{\mathrm{o}}$ 0509503-57.2016.4.02.510198.

Logo em seguida, impetrou-se o Habeas Corpus $\mathrm{n}^{\circ}$ 001277678.2016.4.02.0000 em favor da mesma requerendo a revogação da prisão preventiva e, subsidiariamente, a concessão do benefício de prisão domiciliar, caso não fosse possível obter sua liberdade plena. A alegação veio com base do

\footnotetext{
${ }^{97}$ JFRJ, Justiça Federal do Rio de Janeiro. Processo no 0510203-33.2016.4.02.5101, $7^{\text {a }}$ Vara Federal Criminal, Juiz Dr. Marcelo da Costa Bretas, DJo 06 dez. 2016. Disponível em: $<$ https://www.conjur.com.br/dl/decisao-prisao-adriana-ancelmo.pdf $>$ Acesso em: 31 de mai. 2018.

${ }^{98}$ JFRJ. Justiça Federal do Rio de Janeiro. Processo no 0509503-57.2016.4.02.5101, $7^{\mathrm{a}}$ Vara Federal Criminal, Juiz Dr. Marcelo da Costa Bretas, DJo 20 set. 2017. Disponível em: 〈http://www.mpf.mp.br/rj/sala-de-imprensa/docs/pr-rj/sentenca-calicute> Acesso em: 31 de mai. 2018.
} 
argumento de que havia a necessidade de amparo dos filhos menores de idade, tendo em vista que o marido, Sérgio Cabral, já se encontrava encarcerado ${ }^{99}$.

O Tribunal Regional Federal negou-o liminarmente ${ }^{100}$, entretanto, em março de 2017, o próprio juiz de primeiro grau que decidiu pela prisão preventiva, conferiu à acusada o benefício de responder a ação penal em âmbito de seu domicílio. Para isto, condicionantes foram estabelecidas. ${ }^{101}$

Acontece que o Ministério Público Federal ficou inconformado com a conversão do magistrado e interpôs um Mandado de Segurança $n^{\circ}$ 010007207.2017.4.02.0000 com o objetivo de conferir efeito suspensivo ao recurso cabível como uma forma de "precaução". ${ }^{102}$

No Tribunal Regional Federal, o relator, por sua vez, compactuou com a opinião do Ministério Público Federal e, por liminar concedida, suspendeu-se a decisão do juiz de primeira instância. ${ }^{103}$

No que diz respeito a defesa, esta recorreu no Superior Tribunal de Justiça $\left(\mathrm{HC} \mathrm{n}^{\circ} 383.606 / \mathrm{RJ}\right)$ e a ministra Maria Thereza de Assis Moura concedeu a liminar para suspender a decisão do Tribunal Regional Federal fundado em questões meramente processuais. ${ }^{104}$ Isso pode ser explicado devido ao fato de que o mandado de segurança não foi o instrumento adequado a ser manejado, tendo em vista que este não cabe quando possui recurso previsto, no caso em questão, Recurso em Sentido Estrito. Desta forma, a ministra não se manifestou com relação ao mérito, somente quanto ao erro formal que não comungava com

\footnotetext{
${ }^{99}$ Disponível em: <http://www.ambito-juridico.com.br/site/?n_link=visualiza_noticia\&id_caderno=\& id noticia $=146136>$ Acesso em: 31 de mai. 2018.

100 Disponível em: <http://www.ambito-juridico.com.br/site/?n_link=visualiza_noticia\& id_caderno $=$ \&id noticia $=146136>$ Acesso em: 31 de mai. 2018.

101 Disponível em: <https://politica.estadao.com.br/noticias/geral,juiz-concede-prisao-domiciliar-aadriana-anselmo-mulher-de-cabral,70001704155> Acesso em: 31 de mai. 2018.

102 Disponível em: <http://www10.trf2.jus.br/portal/trf2-revoga-ordem-de-prisao-domiciliar-paraadriana-ancelmo/> Acesso em: 31 de mai. 2018.

103 Disponível em: <https://www.conjur.com.br/2017-mar-20/alegando-isonomia-revoga-domiciliarmulher-sergio-cabral > Acesso em: 31 de mai. 2018.

${ }^{104}$ STJ. Recurso em Habeas Corpus no 383.606/RJ, Min. Relatora: Maria Thereza de Assis Moura, julgado em: 27/02/2018. Disponível em: <https://stj.jusbrasil.com.br/jurisprudencia/554473847 /habeas-corpus-hc-383606-rj-2016-0334469-6/relatorio-e-voto-554473869? ref=juris-tabs\#> Acesso em: 31 de mai. 2018.
} 
a jurisprudência pacífica. Por fim, deveria o Ministério Público Federal aguardar pelo julgamento do Recurso em Sentido Estrito pelo Tribunal Regional Federal. Assim, a acusada permaneceu em prisão domiciliar até novembro de 2017, que foi a época que houve o julgamento do respectivo recurso pela $1^{\text {a }}$ Turma do Tribunal Regional Federal da $2^{a}$ Região, restabelecendo novamente a prisão preventiva. ${ }^{105}$

Logo em seguida, houve brecha para a defesa apresentar embargos infringentes, pois a decisão da turma recursal não fora unânime. Contudo, a $1^{\mathrm{a}}$ Seção do Tribunal manteve a decisão do restabelecimento da prisão preventiva.

Em dezembro daquele mesmo ano, o Habeas Corpus $n^{\circ}$ 151.057/RJ, em favor da acusada fora impetrado em última instância, ou seja, Supremo Tribunal Federal. O resultado foi que o ministro Gilmar Mendes concedeu a liminar para que ela pudesse voltar ao recolhimento domiciliar até a ocorrência do julgamento do Habeas Corpus no STJ. ${ }^{106}$

Finalmente, em 27 de fevereiro de 2018, o referido Habeas Corpus fora julgado, determinando o cumprimento da pena em regime aberto em seu domicílio enquanto perdurar a menoridade dos filhos. ${ }^{107}$

Como foi possível a percepção nestas idas e vindas de remédios constitucionais e liminares, Adriana passou pelo o que milhares de mulheres já sofreram caladas: a negatória de um direito legítimo àquelas que têm filhos até doze anos de idade. Direito este não só previsto no Código de Processo Penal, advento do Estatuto da Primeira Infância, como também amparado pelas Regras de Bangkok, ${ }^{108}$ aprovado internacionalmente pela Organização das Nações Unidas.

105 Disponível em: <https://www.conjur.com.br/2017-abr-26/desembargador-recua-adriana-ancelmoaguardara-recurso-casa $>$ Acesso em: 31 de mai. 2018.

106 STF. Habeas Corpus no 151.057/DF, Min. Relator: Gilmar Mendes, julgado em: 18/12/2017. Disponível em: 〈https://www.conjur.com.br/dl/hc-adriana-ancelmo.pdf > Acesso em: 31 de mai. 2018.

107 Disponível em: <https://www.conjur.com.br/2018-fev-27/stj-confirma-prisao-domiciliar-exprimeira-dama-adriana-ancelmo> Acesso em: 31 de mai. 2018.

${ }_{108}$ CNJ, Regras de Bangkok: Regras das Nações Unidas para o tratamento de mulheres presas $e$ medidas não privativas de liberdade para mulheres infratoras. Brasília. 2016. Disponível em: 
$\mathrm{Na}$ aplicação prática, entretanto, sua garantia de cumprimento é considerada como fenômeno inabitual e pode ser demonstrado no escopo da decisão do desembargador Abel Gomes, responsável este pelo julgamento do recurso no Tribunal Regional Federal da Segunda Região:

A prisão domiciliar de Adriana poderia gerar expectativas vãs ou indesejáveis para as demais mulheres presas que até hoje não foram contempladas por tal substituição. ${ }^{109}$

A utilização de uma fala com lógica tão invertida assim só reafirma a posição de um sistema judiciário conservador e violador de direitos e garantias. Atitude esta completamente incompatível com o Estado Democrático de Direito que preceitua e respeita os direitos humanos, segundo a professora de Direito Penal da Universidade Federal do Rio de Janeiro (UFRJ), Luciana Boiteux:

Em vez de avançar e reafirmar um direito, nós negamos a própria existência desse direito sob a argumentação de que ele não se aplica amplamente. ${ }^{110}$

Esta dialética vinha sendo aplicada há muito tempo nos tribunais pelo país a fora e o caso da Adriana, por ser uma figura pública e pessoa de influência, veio para balançar as estruturas de poder. Felizmente, ao final, funcionou e sua concessão de prisão domiciliar se tornou precedente judicial para muitas outras mulheres presas invisibilizadas.

〈http://www.cnj.jus.br/files/conteudo/arquivo/2016/03/a858777191da58180724ad5caafa6086.pdf $>$ Acesso em: 10 de mar. 2018.

109 Disponível em: <http://ittc.org.br/nota-publica-do-ittc-sobre-a-revogacao-da-prisao-domiciliar-deadriana-ancelmo/> Acesso em 11 de mar. 2018.

110 Disponível em: <https://www.cartacapital.com.br/sociedade/caso-adriana-ancelmo-o-direito-aprisao-domiciliar-negado-a-ricas-e-pobres> Acesso em 11 de mar. 2018. 


\subsubsection{Caso Habeas Corpus no $143.641 / \mathrm{SP}$ (HC Coletivo)}

Como é de se saber, após o caso da concessão da prisão domiciliar à Adriana Ancelmo, o tema "violação dos direitos de mulheres presas que preenchem os requisitos legais para usufruir de medida substitutiva ao encarceramento prisional" tomou grandes proporções.

Esta repercussão trouxe o debate em voga e fez surgir o Habeas Corpus coletivo ( $\left.\mathrm{HC} \mathrm{n}^{\circ} 143.641 / \mathrm{SP}\right)^{111} \mathrm{em}$ prol de diversas mulheres gestantes ou mães de crianças com até doze anos de idade abarcadas em situação de prisão preventiva. $^{112}$

O Coletivo de Advogados em Direitos Humanos (CADHu), impetrante do remédio constitucional em questão, com apoio da Defensoria Pública da União (DPU), utilizou da argumentação das carências, privações e restrições que pode haver em uma prisão com relação a este grupo de mulheres, e por consequência seus filhos. Pode-se citar como exemplo: a dificuldade ou simplesmente a inexistência de programas de saúde pré-natal, ausência de assistência regular no pós-parto e a privação das crianças com relação a condições adequadas para sua formação e desenvolvimento. Entende-se, portanto, que o encarceramento, nos casos elucidados, trespassa a figura do apenado, pois afeta diretamente a vida de seus dependentes. Desta forma, a sistemática violência imposta às mães enquadradas nas situações do artigo 318, incisos III, IV e V do Código de Processo Penal, e suas crianças atenta contra preceitos constitucionais, além do descumprimento de direitos legítimos elencados pelas Lei de Execução Penal (LEP) e também ao Estatuto da Primeira Infância (Lei 13.257/2016).

\footnotetext{
${ }^{111}$ STF. Habeas Corpus $n^{\circ}$ 143.641/SP, Min. Relator: Ricardo Lewandowski, julgado em 20/02/2018 <https://www.conjur.com.br/dl/voto-ministro-ricardo-lewandowski1.pdf $>$ Acesso em: 31 de mai. 2018. 112 Disponível em: <http://portal.stf.jus.br/noticias/verNoticiaDetalhe.asp? idConteudo=370152>Acesso em: 31 de mai.2018.
} 
A situação degradante experimentada pelas mulheres nas situações elencadas nos incisos do referido artigo 318 já foi tema de amplo debate à época da Arguição de Descumprimento de Preceito Fundamental (ADPF) 347 MC/DF, no qual ocorreu a discussão sobre o descumprimento de preceito fundamental no sistema carcerário.

O relator, Ricardo Lewandowski, pautou-se no debate da ADPF 347 MC/DF para constatar a deficiência e endossou a tese amplamente aceita no entendimento jurídico de que fatos notórios independem de provas. Com o remédio constitucional em tela e todos os dados elucidados pela discussão, restou nítida a situação e as ilegalidades perpetradas na administração das penas. Segundo este:

Numa sociedade burocratizada, a lesão pode assumir caráter coletivo e, neste caso, o justo consiste em disponibilizar um remédio efetivo e funcional para a proteção da coletividade.

Temos mais de 2.000 pequenos brasileirinhos que estão atrás das grades com suas mães, sofrendo indevidamente, contra o que dispõe na Constituição, as agruras do cárcere.

Considero que o Supremo deva assumir a responsabilidade com relação aos mais de 100 milhões de processos a cargo de 16 mil juízes e as dificuldades de acesso à justiça e passe a aplicar remédios de maior abrangência, para construir mais isonomia e que lesões a direitos sejam sanadas mais celeremente. ${ }^{113}$

Dos outros ministros, Gilmar Mendes, Dias Toffoli e Celso de Mello acompanharam o voto do relator. $O$ único que divergiu perante a concessão do Habeas Corpus foi Edson Fachin com a argumentação de que não era possível simplesmente a revogação automatizada das prisões já decretadas, mas sim o exercício de uma análise do caso concreto em relação às condições e interesses da singularidade de cada criança.

113 Disponível em: <https://www.conjur.com.br/2018-fev-20/supremo-concede-hc-coletivo-presasgravidas-maes-criancas > Acesso em: 11 de mar. 2018. 
Assim, no dia 20 de fevereiro de 2018, decidiu a $2^{\text {a }}$ Turma do Supremo Tribunal Federal, com um placar de quatro votos a um, a favor da concessão do Habeas Corpus coletivo. Logo, todas as detentas abarcadas pelos pressupostos legais seriam beneficiadas pela prisão domiciliar até o perduro da condição.

A decisão do Supremo determinou um prazo de 60 dias para que todos os magistrados de âmbito federal e estadual regularizassem a situação destas mulheres em questão.

\subsubsection{Caso Danúbia de Souza Rangel}

Outro caso a ser citado é o da Danúbia de Souza Rangel, conhecida como "xerifa" da Rocinha por ser a mulher do ex-chefe do tráfico na Rocinha, "Nem". Ela foi condenada pelos crimes de tráfico de drogas, associação para o tráfico e corrupção ativa em 2016 pela $40^{\mathrm{a}}$ Vara Criminal do Rio de Janeiro (processo $\mathrm{n}^{\circ}$ 0350819-06.2013.8.19.0001). ${ }^{114}$

Sua pena em primeira instância foi determinada em 28 anos de reclusão. A defesa de prontidão recorreu ao TJRJ ( $\mathrm{HC} \mathrm{n}^{\circ}$ 0030049-34.2014.8.19.0000) e o magistrado, por sua vez, não mudou de opinião e manteve a decisão. ${ }^{115}$

Logo em seguida, recorreu-se ao Superior Tribunal de Justiça $\left(\mathrm{RHC} \mathrm{n}^{\circ}\right.$ 73.399/RJ) e, mais uma vez, se depararam com a negatória do pleito. ${ }^{116}$

\footnotetext{
114 TJRJ, Tribunal de Justiça do Rio de Janeiro. Processo no 0350819-06.2013.8.19.0001 - Ação Penal, Procedimento Ordinário, 40 ${ }^{\mathrm{a}}$ Vara Criminal, Juiza Dra. Alessandra de Araujo Bilac Moreira Pinto. Disponível em: $\quad\langle$ http://www4.tjij.jus.br/consultaProcessoWebV2/consultaMov.do? $\mathrm{v}=2 \&$ numProcesso=2013.001.309794-3\&acessoIP=internet\&tipoUsuario=>Acesso em: 31 de mai. 2018.

115 TJRJ, Tribunal de Justiça do Rio de Janeiro. Processo ${ }^{\circ}$ 0030049-34.2014.8.19.0000 - Habeas Corpus, $7^{\text {a }}$ Câmara Criminal, Des. Siro Darlan de Oliveira Disponível em: <http://www4.tjri.jus.br/ ejud/ConsultaProcesso.aspx? $\mathrm{N}=2014.059 .04820 \&$ back=1\&PORTAL=1\&v $=>$ Acesso em: 31 de mai. 2018.

${ }^{116}$ STJ, Supremo Tribunal Federal. Recurso em Habeas Corpus no 73.399/RJ, Min. Relator: Nefi Cordeiro, julgado em: 23/08/2016. Disponível em: <https://ww2.stj.jus.br/processo/revista/ documento/mediado $/$ ?componente $=$ ATC \&sequencial $=63421048 \&$ num_registro $=201601875976 \&$ data $=20160901 \&$ tipo=5\&formato=PDF $>$ Acesso em: 31 de mai. 2018.
} 
Ao chegar no Supremo Tribunal Federal, entretanto, impetrou-se Habeas Corpus $\mathrm{n}^{\mathrm{o}} 153.809 / \mathrm{RJ}^{117}$ em favor da mesma para que houvesse a conversão de sua prisão preventiva em prisão domiciliar sob a alegação da existência de sua filha de 7 anos de idade. ${ }^{118}$

$\mathrm{O}$ argumento da defesa foi baseado em duas decisões anteriores tidas como emblemáticas: a decisão favorável do Habeas Corpus impetrado em favor de Adriana Ancelmo, no qual ela pôde voltar para sua residência para cuidar dos filhos, assim como, a decisão perante o Habeas Corpus coletivo que autorizou a transferência de mulheres grávidas ou mães de crianças de até doze anos de idade, que estivessem em situação de prisão preventiva, para a prisão domiciliar. ${ }^{119}$ Neste sentido, os advogados de Danúbia:

O princípio da igualdade visa dar aos cidadãos tratamento isonômico, vedando as diferenciações arbitrárias e imotivadas.

O atual cenário jurídico aponta, de forma translúcida, pelo direito à convivência familiar - mães e filhos (as) de até 12 anos de idade. Nessa seara, imperioso assinalar a situação fática e jurídica - idêntica - que se encontra a paciente. ${ }^{120}$

Conclui-se então que o caso de Adriana Ancelmo foi paradigmático e contribuiu para a tão almejada política de desencarceramento no país. Depois do respectivo desfecho em inúmeros outros casos, espera-se enfim o reconhecimento do poder judiciário perante o tema da questão de gênero como fator de desigualdade e seus respectivos reflexos no sistema prisional, assim como, o respeito pela legitimidade de seus direitos.

\footnotetext{
117 STF, Supremo Tribunal Federal. Habeas Corpus no 153.809/RJ, Min. Relator: Edson Fachin, julgado em: 07/03/2018. Disponível em: 〈http://www.stf.jus.br/portal/jurisprudencia/ listarJurisprudenciaDetalhe.asp?s1=000408856\&base=baseMonocraticas $>$ Acesso em: 31 de mai. 2018. 118 Disponível em: <http://www.stf.jus.br/portal/cms/verNoticiaDetalhe.asp?idConteudo=371731> Acesso em: 31 de mai. 2018.

${ }^{119}$ Disponível em: <http://www.stf.jus.br/portal/jurisprudencia/listarJurisprudenciaDetalhe.asp?s1=000 408856\&base=baseMonocraticas $>$ Acesso em: 31 de mai. 2018.

${ }_{120}$ Disponível em: <https://noticias.uol.com.br/cotidiano/ultimas-noticias/2018/03/06/mulher-de-nemcita-decisao-do-stf-sobre-maes-presas-para-pedir-prisao-domiciliar.htm> Acesso em: 22 de mar. 2018.
} 


\section{Conclusão}

A conclusão que se chega ao estudar a realidade dos indivíduos do sexo feminino é que a questão de gênero é sim um fator de desigualdade, sobretudo no que concerne ao sistema de justiça criminal. A mulher possui um estigma e isso se desemboca no cárcere, assim como lá dentro se perpetua.

$\mathrm{O}$ aumento da taxa de aprisionamento em $567 \%$ em quatorze anos no Brasil, bem como o delito do tráfico de drogas ser o que mais encarcera mulheres no país (68\% deste total atual), são fatos, no mínimo, alarmantes. Diante deste cenário, destaca-se a necessidade de se identificar os fatores que influenciaram a realidade criminal destes indivíduos do gênero feminino.

No que concerne à questão criminal, pensar na raiz do problema implica na compreensão do sistema econômico e seus respectivos efeitos sociais. As mudanças estruturais ocorridas na América Latina a partir da década de noventa com a entrada do neoliberalismo foram fatores determinantes para a divisão sexual do trabalho e feminização da pobreza. Estes fenômenos possuem relação direta para com a inserção do gênero feminino na atividade ilícita do tráfico de entorpecentes e, consequentemente, ao seu encarceramento em massa diante da lógica punitiva da política de drogas. Não é à toa que a composição da população prisional feminina atual é composta de um perfil específico, qual seja, aquelas predominantemente negras, de baixa renda e cujo enquadramento penal se dá pelo tráfico de drogas.

A crítica, entretanto, se estende à vida delas durante o cumprimento da pena no cárcere. O cometimento de delito por uma mulher é tido como quebra de expectativa da sociedade perante seu papel feminino. Esta enxergada como "transgressora" sofre perpetuação da opressão estrutural sob aspectos do patriarcado, violência contra mulher e invisibilidade dentro das próprias instituições prisionais. O sistema é criado, desenvolvido e voltado para homens 
e a mulher presa se encontra completamente a mercê de suas necessidades específicas.

Apenas recentemente alteraram-se as legislações com intuito de se adaptar a questão de gênero ao sistema prisional. Infelizmente, apesar do grande avanço com relação à sua existência dos direitos das mulheres presas, não é possível afirmar o mesmo com relação à sua aplicação efetiva. Diversos deles ainda são descumpridos sem qualquer tipo de pudor. As violações perpassam setores tais quais: a relação materno-infantil; estabelecimento prisional próprio; acompanhamento à gestante; permanência de agentes penitenciários exclusivamente do sexo feminino; vedação ao uso de algemas em parturientes; ensino profissional completo da mulher; fora as recomendações, tratados ou convenções de âmbito internacional.

Inclusive, vale a especial atenção no que tange à violação ao benefício da prisão domiciliar daquelas abarcadas pelas hipóteses legais, pois o bem jurídico tutelado perpassa a conjuntura da própria mulher encarcerada e atinge outro indivíduo, este inteiramente indefeso e vulnerável. A prisão de uma mulher, portanto, afeta de forma profunda a vida de seus filhos e isso foi trazido em pauta.

Conclui-se, portanto, que a mulher se apresenta vulnerável antes e durante o cometimento do crime, assim como em sua vida no cárcere. Sua vulnerabilidade de gênero é social, pois o mercado de trabalho é opressor e segregatício. Sua vulnerabilidade de gênero atua no âmbito criminal, já que o tráfico de drogas se apresenta como única saída para sua sobrevivência e, por sua vez, propicia a seletividade penal do sistema. Sua vulnerabilidade de gênero continua se reproduzindo dentro da prisão, tendo em vista que esta é sempre relembrada de condição de "criminosa" e invisibilizada em todas as suas necessidades específicas. 
Por fim, o que se afere dos fatos supracitados é a imprescindibilidade do reexame de medidas diante da realidade e perspectiva femininas sob duas óticas diferentes.

Do ponto de vista preventivo, adquirir consciência de que a guerra às drogas é uma guerra contras as mulheres, sobretudo às mulheres negras e de baixa renda, se faz possível o entendimento de que a medida mais urgente a se tomar é a implementação de políticas públicas voltadas a este perfil, assim como a discussão e reformulação da política de drogas.

Agora, com relação aos casos em que já há a privação da liberdade, espera-se o combate ao discurso punitivista e o cumprimento das legislações existentes com recorte de gênero, principalmente no concernente à implementação das penas alternativas ou substitutivas que suportem políticas de desencarceramento, pois o aprisionamento desnecessário é economicamente inviável e também a prisão deve ser operada apenas como ultima ratio.

Só assim, o fenômeno do encarceramento em massa deste gênero será diminuído ou, no mínimo, freado. 


\section{Referências Bibliográficas}

ALBANIO, Nathália Iensen. A (des) obediência da doutrina da proteção integral: uma reflexão sobre os direito adquiridos das crianças e adolescentes $e$ o papel dos entes-partes. XII Seminário Nacional Demandas Sociais e Políticas Públicas na Sociedade Contemporânea - II mostra nacional de trabalhos científicos, edição 2016. Disponível em: $<$ https://online.unisc.br/acadnet/anais/index.php/snpp/article/viewFile/14601/3 316> Acesso em: 16 de abr. 2018.

ALENCASTRO, Paola Larroque. Mães Presidiárias e o Direito da Criança e do Adolescente à Convivência Familiar. Rio Grande do Sul: Trabalho de Conclusão de Curso (graduação), 2015. Disponível em: <http://www3.pucrs.br/pucrs/files/uni/poa/direito/graduacao/tcc/tcc2/trabalhos 2015_1/paola_alencastro.pdf> Acesso em: 08 de abr. 2018.

ALVES, Joseane Duarte Ouro. A criminalização da questão social: uma juventude encarcerada. Juiz de Fora: Universidade Federal de Juiz de Fora. Mestrado em Serviço Social, 2013. Disponível em: 〈http://www.ufjf.br/ppgservicosocial/files/2013/04/joseane.pdf> Acesso em: 13 de mai. 2018.

ANDRADE, Vera Regina Pereira de. Sistema Penal Máximo x Cidadania Mínima: códigos de violência na era da globalização. Porto Alegre: Livraria do Advogado, 2003.

ANGARITA, Torres. Drogas y Criminalidad Femenina en Ecuador: el amor como un fator explicativo en la experiencia de las mulas. Programa de maestria em ciencias sociales. Mención estudios de género y desarrollo, Equador: Facultad Latinoamericana de Ciencias Sociales, 2007.

BAGNASCO. Arnaldo. A economia informal, vol. 18, $\mathrm{n}^{\circ}$ 2, Porto Alegre: Ensaios $\quad$ FEE, $1997 . \quad$ Disponível em: $\langle$ https://revistas.fee.tche.br/index.php/ensaios/article/view/1896/2270〉 Acesso em: 07 de mai. 2018.

BARCINSKI, Mariana. Mulheres no Tráfico de Drogas: A Criminalidade como Estratégia de Saída da Invisibilidade Social Feminina. Contextos Clínicos. Vol. 5, n. 1, 2012. 
BATISTA, Vera Malaguti. Criminologia e Política Criminal. Rio de Janeiro: Revista Internacional de História Política e Cultura Jurídica, vol. 1, nº 2, jul/dez 2009. Disponível em: <http://www.redalyc.org/html/3373/337327171003/> Acesso em: 14 de mar. 2018.

BILIBIO, Gabrielli; BITENCOURT, Camila; BRUM, Eduarda; CORREA, Julia; FAVERO, Itauana; FLORES, Karine; LOPES, Vitória; OLIVEIRA, Aline; ROESLER, Gabriele; SILVA, Nicole; SOUTO, Raquel. Mulheres Encarceradas: A realidade das mulheres nos presídios brasileiros. Revista Interdisciplinar de Ensino, Pesquisa e Extensão, vol. 4, n. 01/2016. Disponível em: $<$ http://revistaeletronica.unicruz.edu.br/index.php/eletronica/article/view/4 743> Acesso em: 28 de abr. 2018.

BOITEUX, Luciana, FERNANDES, Maíra, PANCIERI, Aline e CHERNICHARO, Luciana. Mulheres e crianças encarceradas: um estudo jurídico-social sobre a experiência da maternidade no sistema prisional do Rio de Janeiro. Disponível em: 〈https://www.academia.edu/19036368/ Mulheres_e_Crianças_Encarceradas_um_estudo_jur\%C3\%ADdicosocial_sobr e_a_experiência_da_maternidade_no_sistema_prisional_do_Rio_de_Janeiro> Acesso em: 14 de mar. 2018.

BRAGA, Ana Gabriela, FRANKLIN, Naila Ingrid Chaves. Quando a casa é a prisão: uma análise de decisões de prisão domiciliar de grávidas e mães após a Lei 12.403/2011. Rio de Janeiro: Quaestio Iuris, vol. 09, nº 01, 2016. p. 349375. Disponível em: <http://ittc.org.br/wp-content/uploads/2016/06/Quando a_casa_e_a_prisao_uma_analise_de.pdf> Acesso em: 31 de abr. 2018.

BRAGA, Talita Aguiar. Um Estudo sobre a (In)Aplicabilidade das Regras de Bangkok às Mulheres Presas no Brasil. Mato Grosso do Sul: Congresso Internacional de Direitos Humanos, 2016. Disponível em: <https://cidhsite.files.wordpress.com/2017/05/bn_gt3_22.pdf $>$ Acesso em: 04 de mai. 2018.

BRASIL. Dados Consolidados. Levantamento Nacional de Informações Penitenciárias - InfoPen Mulheres. Departamento Penitenciário Nacional. Ministério da Justiça. Junho/2014. Disponível em: 〈http://www.justica.gov.br/news/estudo-traca-perfil-da-populaçãopenitenciafeminina-no-brasil/relatorio-infopen-mulheres.pdf $>$ Acesso em: 04 de mai. 2018.

. Código de Processo Penal de 03 de outubro de 1941. Palácio do Planalto Disponível em: <http://www.planalto.gov.br/ccivil_03/decretolei/Del3689Compilado.htm> Acesso em: 21 de mai. 2018. 
. Código Penal de 07 de dezembro de 1940. Palácio do Planalto. Disponível em: <http://www.planalto.gov.br/ccivil_03/decretolei/Del2848compilado.htm> Acesso em: 21 de mai. 2018.

. Constituição da República Federativa do Brasil de 1988. Palácio do Planalto. Disponível em: <http://www.planalto.gov.br/ccivil_03/constituicao/ constituicaocompilado.htm $>$ Acesso em: 21 de mai. 2018.

- Dados Consolidados. Levantamento Nacional de Informações Penitenciárias - InfoPen. Departamento Penitenciário Nacional. Ministério da Justiça. Junho/2014. Disponível em: 〈http://www.justica.gov.br/news/mjdivulgara-novo-relatorio-do-infopen-nesta-terca-feira/relatorio-depen-versaoweb.pdf > Acesso em: 01 de jun. 2018.

. Lei n ${ }^{\circ} 11.343$ de 23 de agosto de 2016. Palácio do Planalto. Disponível em: $\langle$ http://www.planalto.gov.br/ccivil_03/_ato2004-006/2006/lei/111343.htm $>$ Acesso em: 21 de mai. 2018.

. Lei no 11.942 de 28 de maio de 2009. Palácio do Planalto. Disponível em: $\langle$ http://www.planalto.gov.br/ccivil_03/_ato2007-010/2009/lei/111942.htm $>$ Acesso em: 21 de mai. 2018.

. Lei $\mathrm{n}^{\circ} 12.121$ de 15 de dezembro de 2009. Palácio do Planalto. Disponível em: <http://www.planalto.gov.br/ccivil_03/_ato20072010/2009/lei/112121.htm?TSPD 101_R0=433698c90ee63d7b58c27d01c76f0 cd8e060000000000000000281d8eb1ffff00000000000000000000000000005b0 d0af200322b2d9c> Acesso em: 21 de mai. 2018.

. Lei n 13.257 de 08 de março de 2016. Palácio do Planalto. Disponível em: $\langle$ http://www.planalto.gov.br/ccivil_03/_ato2015-018/2016/lei/113257.htm $>$ Acesso em: 21 de mai. 2018.

. Lei no 13.434 de 12 de abril de 2017. Palácio do Planalto. Disponível em: $<$ http://www.planalto.gov.br/ccivil_03/_ato2015018/2017/lei/L13434.htm? TSPD 101_R0=92e4202b6734434490b551e7dbbede1djK5000000000000000 0281d8eb1ffff00000000000000000000000000005b0d0b1b00de5d0f72> Acesso em: 21 de mai. 2018.

. Lei no 7.209 de 11 de julho de 1984. Palácio do Planalto. Disponível em:〈http://www.planalto.gov.br/ccivil_03/Leis/1980-1988/L7209.htm> Acesso em: 21 de mai. 2018. 
. Lei no 7.210 de 11 de julho de 1984. Palácio do Planalto. Disponível em: 〈http://www.planalto.gov.br/ccivil 03/leis/17210compilado.htm> Acesso em: 21 de mai. 2018.

. Lei $\mathrm{n}^{\circ} 7.960$ de 21 de dezembro de 1989. Palácio do Planalto. Disponível em: <http://www.planalto.gov.br/ccivil_03/Leis/L7960.htm?TSPD _101_R0=17f9de7e79a4f3ef9db02ef70fbb8b27p440000000000000000281d8e b1ffff00000000000000000000000000005b0d0b8d00811db913> Acesso em: 21 de mai. 2018.

. Lei no 8.069 de 13 de julho de 1990. Palácio do Planalto. Disponível em: 〈http://www.planalto.gov.br/ccivil_03/leis/18069.htm> Acesso em: 21 de mai. 2018.

. Lei $\mathrm{n}^{\circ} 8.072$ de 25 de julho de 1990. Palácio do Planalto. Disponível em: 〈http://www.planalto.gov.br/ccivil 03/leis/L8072.htm> Acesso em: $21 \mathrm{de}$ mai. 2018.

. Lei $\mathrm{n}^{\circ} 9.099$ de 26 de setembro de 1995. Palácio do Planalto. Disponível em: <http://www.planalto.gov.br/ccivil_03/Leis/L9099.htm?TSPD _101_R0=eda6869d1fa462c2ec710f2a92684242s720000000000000000281d8 eb1ffff00000000000000000000000000005b0d0b51004afc2290> Acesso em: 21 de mai. 2018.

. Lei n 9.460 de 04 de junho de 1997. Palácio do Planalto. Disponível em: 〈http://www.planalto.gov.br/ccivil 03/leis/L9460.htm> Acesso em: $21 \mathrm{de}$ mai. 2018.

- Ministério da Saúde. Saúde da Criança: Nutrição Infantil: Aleitamento Materno e Alimentação Complementar. Série A. Normas e Manuais Técnicos - Cadernos de Atenção Básica, $\mathrm{n}^{\circ}$ 23. Brasília: Editora Ministério da Saúde, 2009. Disponível em: <http://bvsms.saude.gov.br/bvs/publicacoes/ saude_crianca_nutricao_aleitamento_alimentacao.pdf> Acesso em: 05 de abr. 2018.

BRASILEIRO, Renato. Manual de Direito Processual Penal. $3^{\text {a }}$ edição. Salvador: Juspodivm, 2015.

BRUSCHINI, Cristina; HIRATA, Helena (orgs). Divisão sexual do trabalho profissional e doméstico: Brasil, França e Japão. Rio de Janeiro: Editora FGV, 2008. 
BUTLER, Judith. Problemas de gênero: feminismo e subversão da identidade. Rio de Janeiro: Civilização Brasileira, 2003. Disponível em: $<$ https://cadernoselivros.files.wordpress.com/2017/04/butler-problemasdegener -ocr.pdf> Acesso em: 12 de mar. 2018

CARVALHO. Maria Luciene Barbosa; FREITAS. Luana Duarte Assunção. As faces e os disfarces dos presidios femininos: violações $x$ direitos. XII Brasil: Seminário Nacional Demandas Sociais e Políticas Públicas na Sociedade Contemporânea. II Mostra Nacional de Trabalhos Científicos, edição 2016. Disponível em: <http://online.unisc.br/acadnet/anais/index.php/snpp/ article/view/14582/3270> Acesso em: 22 de abr. 2018.

CASSOL, Paula Dürks. Do Gênero para além do Gênero: a crítica feminista ao direito e à criminologia. Florianópolis: Seminário Internacional Fazendo o Gênero 11 \& 13th Women's Worlds Congress (Anais Eletrônicos), 2017. Disponível em: <http://www.en.wwc2017.eventos.dype.com.br/resources /anais/1498850694_ARQUIVO Artigo\%27Dogeneroparaalemdogenero.pdf > Acesso em: 14 de mar. 2018.

CEBRIAN, Alexandre e GONÇALVES, Victor. Direito Processual Penal Esquematizado. $2^{\mathrm{a}}$ edição. São Paulo: Saraiva, 2013.

CEDES. Avanços do Marco Legal da Primeira Infância. Brasília: Caderno de Trabalhos e Debates 1, 2016. Disponível em: 〈http://www2.camara.leg.br/acamara/estruturaadm/altosestudos/pdf/obra-avancos-do-marco-legal-daprimeira-infancia> Acesso em: 02 de jun. 2018.

CEJIL e outros. Relatório sobre Mulheres Encarceradas no Brasil. Brasil: Fev/2017. Disponível em: <http://carceraria.org.br/wp-content/uploads/2013 /02/Relatório-para-OEA-sobre-Mulheres-Encarceradas-no-Brasil-2007.pdf $>$ Acesso em: 03 de jun. 2018.

CERNEKA. Heidi Ann. Homens que menstruam: considerações acerca do sistema prisional às especificidades da mulher, vol. $6, \mathrm{n}^{\circ}$ 11, Belo Horizonte: Veredas do Direito, 2009. Disponível em: <http://www.domhelder.edu.br/veredas_direito/pdf/60_77.pdf $>$ Acesso em: 24 de abr. 2018.

CIDH. Convenção Interamericana para Prevenir, Punir e Erradicar a Violência contra a Mulher ("Convenção Belém-do-Pará"). Brasil, 1994. Disponível em: <http://www.cidh.org/Basicos/Portugues/m.Belem.do.Para.htm> Acesso em: 02 de jun. 2018. 
CHERNICHARO, Luciana Peluzio. Sobre mulheres e prisões: seletividade de gênero e crime de tráfico de drogas no Brasil. Dissertação de Mestrado da Faculdade Nacional de Direito da Universidade Federal do Rio de Janeiro, 2014. CNJ, Regras de Bangkok: Regras das Nações Unidas para o tratamento de mulheres presas e medidas não privativas de liberdade para mulheres infratoras. Brasília. 2016. Disponível em: <http://www.cnj.jus.br/files/conteudo/arquivo/ 2016/03/a858777191da58180724ad5caafa6086.pdf > Acesso em: 10 de mar. 2018.

DE SÁ, Alvino Augusto, Criminologia Clínica e Psicologia Criminal, $2^{\mathrm{a}}$ ed. rev., atual. e ampl. - São Paulo: Editora Revista dos Tribunais, 2013.

DINIZ, Debora. Cadeia - Relatos sobre mulheres. $2^{\text {a }}$ edição. Sinopse. Rio de Janeiro: Civilização Brasileira, 2016.

EUA. Parental Incarceration and Child Wellbeing in Fragile Families. New Jersey: Fragile Families Research Brief, $\mathrm{n}^{\circ} 42$ - Bendheim-Thoman Center for Research on Child Wellbeing, Princeton University, abril/2008. Disponível em: $<$ https://fragilefamilies.princeton.edu/sites/fragilefamilies/files/researchbrie f42.pdf> Acesso em: 06 de mar. 2018.

FÉLIX, Ynes da Silva. Mulher, estranha e condenada: sobre as imigrantes que cumprem pena privativa de liberdade no Brasil. Curitiba: Revista Jurídica vol. 4, $\mathrm{n}^{\mathrm{o}}$ 49, 2017. Disponível em: <http://revista.unicuritiba.edu.br/index. php/RevJur/article/viewFile/2295/142> Acesso em: 02 de jul. 2018.

FERRAJOLI, Luigi. Direito e Razão: teoria do garantismo penal. Tradução: Ana Paula Zomer, Fauzi Hassan Chower, Juarez Tavares e Luiz Flávio Gomes. São Paulo: Revista dos Tribunais, 2002.

FERREIRA, Aurélio Buarque de Holanda. Mini Aurélio: O dicionário da língua portuguesa. $6^{\mathrm{a}}$ edição revista e atualizada, $5^{\mathrm{a}}$ impressão. Curitiba: Editora Positivo, 2016.

FIGUEIRA, Ana Carolina dos Reis. Questões de Gênero no Sistema Prisional Brasileiro. Minas Gerais: Trabalho de Conclusão de Curso (graduação), 2017. Disponível em: <http://www.faculdadesabara.com.br/wp-content/uploads/ Monografia-Questões-de-Gênero-no-Sistema-Prisional-Brasileiro.pdf $>$ Acesso em: 26 de mai. 2018.

FILHO, Fernando da Costa Tourinho. Manual de Processo Penal. $16^{\mathrm{a}}$ edição, revista e atualizada. São Paulo: Saraiva, 2013. 
FOUCALT, Michel. Vigiar e Punir: Nascimento das prisões. $30^{\mathrm{a}}$ ed. Petrópolis: Vozes, 2004.

ITTC. Mulheres sem prisão: desafios e possibilidades para reduzir a prisão provisória de mulheres. São Paulo, 2017. Disponível em: <http://ittc.org.br/wpcontent/uploads/2017/03/relatorio_final_online.pdf $>$ Acesso em: 15 de mar. 2018.

GECAp. A Constituição Federal, a Lei de Execução Penal e o preso - 7 informações básicas sobre encarceramento. São Paulo: Universidade de São Paulo, 2012. Disponível em: <http://www.gecap.direitorp.usp.br/index. php/noticias/43-a-constituicao-federal-a-lei-de-execucao-penal-e-o-preso-7informacoes-basicas-sobre-encarceramento $>$ Acesso em: 18 de abr. 2018.

GRECO, Luis. Modernização do direito penal, bens jurídicos coletivos e crimes de perigo abstrato. Rio de Janeiro: Lumen Juris, 2011.

HIRATA, Helena; KERGOAT, Danièle. La división sexual del trabajo: Permanencia y cambio. Buenos Aires: Asociación Trabajo y Sociedad, 1997.

; KERGOAT, Danièle. Mercado de trabalho e gênero: comparações internacionais. In: COSTA, Albertina de Oliveira; SORJ, Bila;

IAMAMOTO, Marilda Villela. Serviço social em tempo de capital fetiche: capital financeiro, trabalho e questão social. $7^{\mathrm{a}}$ edição. São Paulo: Cortez, 2012. Disponível em: <http://www.cortezeditora.com.br/newsite/ primeiraspaginas/servico_social_em_tempo.pdf $>$ Acesso em: 03 de mai. 2018.

IBGE. Pesquisa Nacional por Amostra de Domicílio Contínua (PNAD). Brasil: 2017. Disponível em: $<$ https://agenciadenoticias.ibge.gov.br/media/ com_mediaibge/arquivos/4581438d7e04a73aede241d3327e4187.pdf $>$ Acesso em: 03 de mai. 2018.

ICRP. World Female Imprisonment List, fourth edition. World Prison Brief. Londres: Birkbeck University of London, 2017. Disponível em: $<$ http://www.prisonstudies.org/sites/default/files/resources/downloads/worl d_female_prison_4th_edn_v4_web.pdf> Acesso em: 04 de mai. 2018.

JFRJ. Justiça Federal do Rio de Janeiro. Processo $\mathrm{n}^{\mathrm{o}}$ 050950357.2016.4.02.5101, $7^{\mathrm{a}}$ Vara Federal Criminal, Juiz Dr. Marcelo da Costa Bretas, DJo 20 set. 2017. Disponível em: <http://www.mpf.mp.br/rj/sala-deimprensa/docs/pr-rj/sentenca-calicute > Acesso em: 31 de mai. 2018. 
Processo $\mathrm{n}^{\mathrm{o}}$ 051020333.2016.4.02.5101, $7^{\mathrm{a}}$ Vara Federal Criminal, Juiz Dr. Marcelo da Costa Bretas, DJo 06 dez. 2016. Disponível em: <https://www.conjur.com.br/dl/decisaoprisao-adriana-ancelmo.pdf $>$ Acesso em: 31 de mai. 2018.

KARAM, Maria Lucia. Políticas de drogas: alternativas à repressão penal, v. 12, n. 47, São Paulo: Revista Brasileira de Ciências Criminais, mar./abr. 2004.

KRAMER, H.; SPRENGER, J. O Martelo das Feiticeiras: Malleus Maleficarum. $8^{a}$ edição, Rio de Janeiro: Editora Rosa dos Tempos, 1991.

MARTINS, Sérgio Pinto. Comentários à CLT. 8ª edição. São Paulo: Atlas, 2004.

MAURIEL, Ana Paula Ornellas. Combate à pobreza e (des) proteção social: dilemas teóricos das novas políticas sociais. In: Estudos de Política e Teoria Social, $\mathrm{n}^{\mathrm{o}} 14$ e 15. Rio de Janeiro: Editora UFRJ, 2006. Disponível em: 〈https://docs.google.com/file/d/0B0--tS_Kbeq-MmlfeEc5RkNuY3M/edit> Acesso em: 02 de mai. 2018.

MAXIMILIANO, Carlos. Hermenêutica e Aplicação do Direito. $20^{a}$ edição. Rio de Janeiro: Forense, 2011.

MENDES, Kíssila Teixeira. As políticas criminais e o neoliberalismo no Brasil: debates atuais. v. 13, n. 1, IFCS/UFRJ, Rio de Janeiro: Revista Habitus, Semestral, 15 julho 2015.

MIRANDA, Aline Barbosa de; MIRANDA, Gilberto José; VERÍSSIMO, Michele Polline. Ajuste neoliberal e a crise do Estado: necessidade de se retomar a autonomia dos Estados nacionais. Uberlândia: anais do IV Simpósio Internacional: o Estado e as Políticas Educacionais no Tempo Presente, 2008. Disponível em: <http://www.simposioestadopoliticas.ufu.br/imagens/anais/pdf/ AC04.pdf $>$ Acesso em: 14 de mai. 2018.

MIYAMOTO, Yumi; KROHLING, Aloísio. Sistema Prisional Brasileiro sob a Perspectiva de Gênero: Invisibilidade e Desigualdade Social da Mulher Encarcerada. Rio de Janeiro: Direito, Estado e Sociedade - nº 40, jan/jun 2012. Disponível em: <http://direitoestadosociedade.jur.puc-rio.br/media/9artigo 40.pdf> Acesso em: 22 de mai. 2018.

MORETTO, Thaís Zanetti de Mello. Da realidade social ao discurso jurídicopenal: $O$ encarceramento feminino por tráfico de drogas e o insucesso do proibicionismo criminalizador (análise qualitativa e quantitativa). Rio de Janeiro: Lumen Juris, 2014. 
MOURA, Maria Jurena. Porta fechada, vida dilacera - mulher, tráfico de drogas e prisão: estudo realizado no presídio feminino do Ceará. Ceará: Dissertação de Mestrado. Programa de Pós-Graduação em Políticas Públicas e Sociedade. Universidade Estadual do Ceará, 2005. Disponível em: $<$ http://www.uece.br/politicasuece/dmdocuments/dissertacao_juruena mou ra.pdf $>$ Acesso em: 09 de mai. 2018.

MÜLLER, Mauro Marques. A Transição Ideológica para o Neoliberalismo no Brasil Contemporâneo (1979 a 1994). Rio Grande do Sul: Revista Sociais e Humanas da Universidade Federal de Santa Maria vol. 13, no 1, 2003. Disponível em: <https://periodicos.ufsm.br/sociaisehumanas/article/view/ 1226> Acesso em: 31 de abr. 2018.

NASCIMENTO, Priscílla da Fonsêca. Mulheres do Cárcere: da invisibilidade à política nacional de atenção as mulheres em situação de privação de liberdade. Maranhão: VIII Jornada Internacional de Políticas Públicas, 2017. Disponível em: <http://www.joinpp.ufma.br/jornadas/joinpp2017/pdfs/eixo7/ mulheresdocarceredainvisibilidadeapoliticanacionaldeatencaoasmulheresemsit uacaodepri.pdf > Acesso em: 29 de abr. 2018.

NETTO, Helena Henkin Coelho; BORGES, Paulo César Corrêa. A Mulher e o Direito Penal Brasileiro: entre a criminalização pelo gênero e a ausência de tutela penal justificada pelo machismo. São Paulo: Revista de Estudos Jurídicos UNESP, a.17, $\mathrm{n}^{\circ}$ 25, 2013. Disponível em: <https://ojs.franca.unesp.br/ index.php/estudosjuridicosunesp/article/viewFile/927/917> Acesso em: 15 de mai. 2018.

NOVELLINO, Maria Salet Ferreira. Os Estudos sobre Feminização da Pobreza e Políticas Públicas para Mulheres. Minas Gerais: XXVIII Encontro Anual da ANPOCS, 2004. Disponível em: <https://anpocs.com/index.php/papers-28encontro/st-5/st23-2/4076-mnovellino-os-estudos/file> Acesso em: 03 de mai. 2018.

OEA, Comissão de Direitos Humanos, Relatório sobre a situação dos direitos humanos no Brasil, 1996. Disponível em: <http://www.oas.org/main/ portuguese/> Acesso em: 04 de mai. 2018.

OLIVEIRA, Anna Caroline Lopes de Oliveira. A Influência da Convenção de Belém do Pará na Prevenção da Violência contra as Mulheres no Brasil, Chile e Guatemala. Trabalho de Conclusão de Curso (Graduação). Brasília: Centro Universitário de Brasília, Brasília, 2017. Disponível em: $\langle$ http://repositorio.uniceub.br/bitstream/235/11151/1/21391717.pdf > Acesso em: 02 de jun. 2018. 
ONU, Comissão de Direitos Humanos, Relatório sobre a Tortura no Brasil, 1997. Disponível em: <http://www.global.org.br/portuguese/arquivos/ tortura1.pdf> Acesso em: 04 de mai. 2018.

ONU, Relatório Transformando promessas em ações: igualdade de gênero na agenda 2030 para o desenvolvimento sustentável. Grupo de trabalho da sociedade civil para agenda 2030. Brasil: junho/2017. Disponível em: 〈http://www.unwomen.org/en/digital-library/sdg-report $>$ Acesso em: 02 de mai. 2018.

ONU. Regras das Nações Unidas para o Tratamento de Mulheres Presas e Medidas Não Privativas de Liberdade para Mulheres Infratoras ("Regras de Bangkok"). Tradução (Brasília, 2016): Conselho Nacional de Justiça e Departamento de Monitoramento e Fiscalização do Sistema Carcerário e do Sistema de Execução de Medidas Socioeducativas. Bangkok, 2010. Disponível em: $<$ http://www.cnj.jus.br/files/conteudo/arquivo/2016/03/a858777191da5818 0724ad5caafa6086.pdf $>$ Acesso em: 02 de jun. 2018.

PANCIERI, Aline Cruvello. Mulheres mulas: seletividade, tráfico de drogas e vulnerabilidade de gênero. Rio de Janeiro: Monografia (Graduação em Direito) - Universidade Federal do Rio de Janeiro, Rio de Janeiro, 2014. Disponível em: <https://www.academia.edu/11674495/Mulheres_Mulas_Seletividade_Tráfico _de Drogas e Vulnerabilidade de Gênero> Acesso em: 01 de jun. 2018.

PEREIRA, Larissa Urruth; ÁVILA, Gustavo Noronha de. Política de drogas e aprisionamento feminino - o tráfico e o uso na lei de drogas. Rio Grande do Sul: Revistas da Pontifícia Universidade Católica do Rio Grande do Sul. Ciências Criminais. E-book. Disponível em: <http://ebooks.pucrs.br/edipucrs/ anais/cienciascriminais/IV/46.pdf $>$ Acesso em: 03 de mai. 2018.

PIERCE, Diane. The feminization of poverty: women, work and welfare. Washington: Urban and Social Change Review, 1978.

PINTO, Camila Franco de Souza Reis. Prisão Cautelar: Os requisitos do artigo 312, CPP e as mudanças trazidas pelo anteprojeto. Brasília: Instituto Brasiliense de Direito Público, 2010. Disponível em: <http://dspace.idp.edu.br:8080/xmlui/ bitstream/handle/123456789/247/Monografia_Camila\%20Franco\%20de\%20S ouza\%20Reis\%20Pinto.pdf? sequence $=1$ \&isAllowed=y $>$ Acesso em: $12 \mathrm{de}$ abr. 2018.

PNUD, IPEA, FJP. Desenvolvimento humano para além das médias. Brasília, 2017. Disponível em: <http://www.br.undp.org/content/dam/brazil/docs/

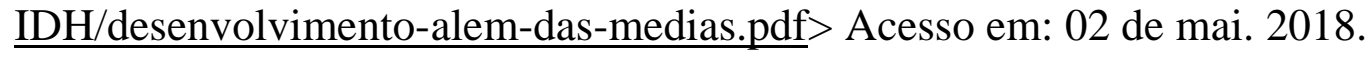


QUADROS, Pedro Oto; SANTA RITA, Rosangela Peixoto. Amamentação: direito da mãe ou da criança? Um olhar sobre as práticas do encarceramento feminino. Florianópolis: Tese para o Congresso da Associação Brasileira de Magistrados e Promotores de Justiça da Infância e da Juventude, 2008.

QUEIROZ, Nana. Presos que menstruam: A brutal vida das mulheres - tratadas como homens - nas prisões brasileiras. Rio de Janeiro: Record, 2015.

RAMOS, Luciana de Souza. Por amor ou pela dor? Um olhar feminista sobre o encarceramento por tráfico de drogas. Brasília: Dissertação de Mestrado. Faculdade de Direito da Universidade de Brasília. Brasília, 2012. Disponível em:

<http://repositorio.unb.br/bitstream/10482/13758/1/2012_LucianadeSouzaRam os.pdf> Acesso em: 02 de mai. 2018.

REGO. José Dias. Aleitamento materno. $2^{\mathrm{a}}$ edição. São Paulo: Atheneu, 2006.

SÁ, Alvino Augusto de. Criminologia Clínica e Psicologia Crimininal. São Paulo: Editora Revista dos Tribunais, $2^{\text {a }}$ ed. revista, atualizada e ampliada, 2010. Disponível em: <https://edisciplinas.usp.br/pluginfile.php/3927023/ mod resource/content/4/Alvino\%20-\%20prisionizacao\%20-20um\%20dilema \%20para\%20o\%20carcere $\% 20 \mathrm{e} \% 20 \mathrm{um} \% 20$ desafio $\% 20$ para $\% 20 \mathrm{a} \% 20$ socieda de.pdf> Acesso em: 04 de jun. 2018.

SADER, Emir. A construção da hegemonia pós-neoliberal. In: SADER, Emir (org). 10 anos de governos pós-neoliberais no Brasil: Lula e Dilma. São Paulo: Editora Boitempo, 2013.

SOARES, Bárbara, ILGENFRITZ, Iara. Prisioneiras: vida e violência atrás das grades. Rio de Janeiro: Garamond. 2002.

SOBRINHO, Sergio Francisco Carlos Graziano. Os Impactos Econômicos da Atuação do Sistema Penal: vida virtual, isolamento e encarceramento em massa. Porto Alegre: Pontifícia Universidade Católica do Rio Grande do Sul, 2014. Disponível em: 〈http://www.scielo.br/pdf/seq/n69/06.pdf> Acesso em: 21 de mar. 2018.

SOUZA, Jessé. Ralé brasileira: quem é e como vive. Belo Horizonte: Editora UFMG, 2009. Disponível em: <http://flacso.redelivre.org.br/files/2014/ 10/1143.pdf $>$ Acesso em: 02 de mai. 2018. 
SOUZA, José Barcelos. A Renovação Processual Penal após a Constituição de 1988. Rio de Janeiro: Editora Lumen Juris, 2009.

SOUZA, Simone Brandão. Criminalidade Feminina: trajetórias e confluências na fala de presas do Talavera Bruce. Rio de Janeiro: Dissertação de mestrado. Escola Nacional de Ciências Estatísticas. Universidade Federal do Rio de Janeiro, 2005. Disponível em: <http://www.observatoriodeseguranca.org/ files/dv33 artigo2.pdf> Acesso em: 08 de mai. 2018.

STJ, Superior Tribunal de Justiça. Habeas Corpus no 143.641/SP, Min. Relator: Ricardo Lewandowski, julgado em: 20/02/2018. Disponível em: $\langle$ https://www.conjur.com.br/dl/voto-ministro-ricardo-lewandowski1.pdf $>$ Acesso em: 31 de mai. 2018.

Gilmar Mendes, julgado em: 18/12/2017. Disponível em:
〈https://www.conjur.com.br/dl/hc-adriana-ancelmo.pdf $>$ Acesso em: 31 de mai. 2018.

Edson Fachin, julgado em: 07/03/2018. Disponível em: <http://www.stf.jus.br/portal/jurisprudencia/listarJurisprudenciaDetalhe.asp?s1 $=000408856 \&$ base $=$ baseMonocraticas $>$ Acesso em: 31 de mai. 2018.

. Habeas Corpus n ${ }^{\circ} 394.039 / \mathrm{SP}$, Min. Relator:

Joel Ilan Paciornik, julgado em 23/05/2017. Disponível em: <https://stj.jusbrasil.com.br/jurisprudencia/468929794/habeas-corpus-hc394039-sp-2017-0070368-0/inteiro-teor-468929795?ref=juris-tabs\#> Acesso em: 31 de mar. 2018.

. Recurso em Habeas Corpus $n^{\circ} 383.606 / \mathrm{RJ}$, Min. Relatora: Maria Thereza de Assis Moura. Julgado em: 27/02/2018. Disponível em: <https://sti.jusbrasil.com.br/jurisprudencia/554473847/habeascorpus-hc-383606-rj-2016-0334469-6/relatorio-e-voto-554473869?ref=juristabs\#> Acesso em: 31 de mai. 2018.

Min. Relator: Nefi Cordeiro. Disponível em: <https://ww2.stj.jus.br/processo/revista/documento/mediado/?componente=AT C\&sequencial $=63421048 \&$ num_registro $=201601875976 \&$ data $=20160901 \&$ tip

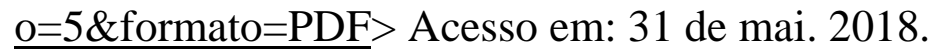

. Recurso em Habeas Corpus $n^{\circ}$ 83.488/SP,

Min. Relator: Jorge Mussi, julgado em 23/05/2017. Disponível em: 
<https://stj.jusbrasil.com.br/jurisprudencia/467851222/recurso-ordinario-emhabeas-corpus-rhc-83488-sp-2017-0091583-9/inteiro-teor-467851235\#>

Acesso em: 31 de mar. 2018.

TEIXEIRA, Daniel Viana. Desigualdade de gênero: sobre garantias e responsabilidades sociais de homens e mulheres. São Paulo: Revista Direito GV, Jan-Jun 2010.2 Disponível em: <http://www.scielo.br/pdf/rdgv/v6n1/12.pdf> Acesso em: 04 de mai. 2018.

TERRA, Osmar. A importância dos primeiros anos de vida. Revista de Informação Legislativa A 44, $\mathrm{n}^{\mathrm{o}}$ 176. Brasília, 2007. Disponível em: $\langle\underline{\text { https://www12.senado.leg.br/ril/edicoes/44/176/ril_v44_n176_p95.pdf }>}$ Acesso em: 10 de mar. 2018.

THOMPSON, Augusto. A Questão Penitenciária. $5^{\text {a }}$ Ed. Rio de Janeiro: Editora Forense, 2002.

Quem são os criminosos? O crime e o criminoso: Entes políticos. $2^{\text {a }}$ Ed. Rio de Janeiro: Lumen Juris Editora, 2007.

TJRJ, Tribunal de Justiça do Rio de Janeiro. Processo $\mathrm{n}^{\circ}$ 003004934.2014.8.19.0000 - Habeas Corpus, $7^{\mathrm{a}}$ Câmara Criminal, Des. Siro Darlan de Oliveira Disponível em: <http://www4.tjri.jus.br/ejud/ConsultaProcesso.aspx? $\mathrm{N}=2014.059 .04820 \& b a c$ $\mathrm{k}=1 \& \mathrm{PORTAL}=1 \& \mathrm{v}=>$ Acesso em: 31 de mai. 2018.

. Processo $\mathrm{n}^{\mathrm{o}}$ 035081906.2013.8.19.0001 - Ação Penal, Procedimento Ordinário, 40ª Vara Criminal, Juiza Dra. Alessandra de Araujo Bilac Moreira Pinto. Disponível em: 〈http://www4.tjri.jus.br/consultaProcessoWebV2/consultaMov.do?v=2\& numProcesso=2013.001.309794-3\&acessoIP=internet\&tipoUsuario $=>$ Acesso em: 31 de mai. 2018.

TRIBE, Laurence; Dorf, Michael. Hermenêutica Constitucional. Tradução de Amarílis de Souza Birchal; Coordenação e supervisão de Luiz Moreira. Belo Horizonte: Del Rey, 2007.

ZAPATER. Maíra Cardoso. O Código Penal de 1940: não parece que foi ontem? Coluna: A herança legal das ditaduras: nossas cicatrizes jurídicas. Revista Carta Capital. Brasil, 3 jun. 2016. Disponível em: $<$ http://justificando.cartacapital.com.br/2016/06/03/o-codigo-penal-de-1940nao-parece-que-foi-ontem/> Acesso em: 05 de abr. 2018. 
WENDY, Miguel Tedesco. Teoria Geral da Prisão Cautelar e Estigmatização. Rio de Janeiro: Editora Lumen Juris, 2006.

$<$ http://www.ambitojuridico.com.br/site/?n_link=visualiza_noticia\&id_cadern

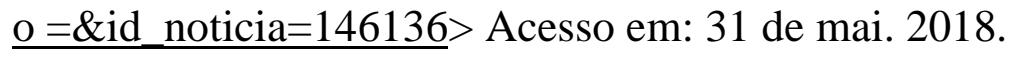

〈http://ittc.org.br/nota-publica-do-ittc-sobre-a-revogacao-da-prisao-domiciliarde-adriana-ancelmo/> Acesso em: 11 de mar. 2018.

〈http://ittc.org.br/questoes-de-genero-nos-presidios-do-brasil/> Acesso em: 12 de mar. 2018.

$<$ http://ittc.org.br/stf-reconhece-regras-bangok-como-meio-desencarcerarmulheres/> Acesso em: 12 de mar. 2018.

〈http://portal.stf.jus.br/noticias/verNoticiaDetalhe.asp?idConteudo=370152 $>$ Acesso em: 31 de mai. 2018.

<http://www.bbc.com/portuguese/brasil-38590880 > Acesso em: 05 de abr. 2018.

〈http://www.stf.jus.br/portal/cms/verNoticiaDetalhe.asp?idConteudo=371731 > Acesso em: 31 de mai. 2018.

< http://www10.trf2.jus.br/portal/trf2-revoga-ordem-de-prisao-domiciliar-paraadriana-ancelmo/> Acesso em: 31 de mai. 2018.

$<$ https://nacoesunidas.org/conselho-nacional-de-justica-publica-versao-emportugues-de-regras-da-onu-sobre-detencao-de-mulheres> Acesso em: 06 de abr. 2018.

〈https://noticias.uol.com.br/cotidiano/ultimas-noticias/2018/03/06/mulher-denem-cita-decisao-do-stf-sobre-maes-presas-para-pedir-prisao-domiciliar.htm> Acesso em: 22 de mar. 2018.

<https://politica.estadao.com.br/noticias/geral,juiz-concede-prisao-domiciliara-adriana-anselmo-mulher-de-cabral,70001704155> Acesso em: 31 de mai. 2018.

$<$ https://ponte.org/mesmo-com-mudancas-na-lei-brasil-nao-garante-direitosdas-gravidas-presas/> Acesso em: 01 de jun. 2018. 
<https://ponte.org/ser-mulher-em-um-sistema-prisional-feito-por-e-parahomens/> Acesso em: 01 de jun. 2018.

<https://www.cartacapital.com.br/sociedade/caso-adriana-ancelmo-o-direito-aprisao-domiciliar-negado-a-ricas-e-pobres> Acesso em: 11 de mar. 2018.

〈https://jus.com.br/artigos/36654/formas-de-interpretacao-do-direito\#_ftn5> Acesso em: 31 de mai. 2018.

<https://marcelofidalgoneves.jusbrasil.com.br/artigos/348336409/prisaocautelar-e-prisao-preventiva > Acesso em: 31 de mai. 2018.

$<$ https://davidmaxsuel.jusbrasil.com.br/artigos/375660788/art-318-cpp-prisaodomiciliar-sob-a-otica-da-lei-n-13257-2016> Acesso em: 31 de mai. 2018.

<https://noticias.cers.com.br/noticia/lei-1343417/> Acesso em:31 de mai. 2018.

<https://medium.com/@ prioridadeabsoluta/por-uma-infância-livre-os-direitosde-crianças-e-mães-encarceradas-2d48d9be1959>> Acesso em: 31 de mai. 2018.

<https://www.conjur.com.br/2010-jan-04/presidios-mulheres-terao-substituiragentes-sexo-masculino> Acesso em: 01 de jun. 2018.

<http://www.dizerodireito.com.br/2016/03/comentarios-lei-132572016estatuto-da.html > Acesso em: 31 de mai. 2018.

<https://www.conjur.com.br/2017-mar-20/alegando-isonomia-revogadomiciliar-mulher-sergio-cabral> Acesso em: 31 de mai. 2018.

<https://www.conjur.com.br/2017-abr-26/desembargador-recua-adrianaancelmo-aguardara-recurso-casa $>$ Acesso em: 31 de mai. 2018.

<http://meusitejuridico.com.br/2017/06/26/prisao-domiciliar-no-cpp-e-na-leide-execucao-penal/> Acesso em: 31 de mai. 2018.

<https://www.conjur.com.br/2018-fev-20/supremo-concede-hc-coletivopresas-gravidas-maes-criancas > Acesso em: 11 de mar. 2018.

<https://www.conjur.com.br/2018-fev-27/stj-confirma-prisao-domiciliar-exprimeira-dama-adriana-ancelmo> Acesso em: 31 de mai. 2018. 
$<$ http://agenciabrasil.ebc.com.br/geral/noticia/2018-03/cnj-apontaprecariedade-em-penitenciarias-que-abrigam-gestantes-e-lactantes $>$ Acesso em: 05 de abr. 2018. 